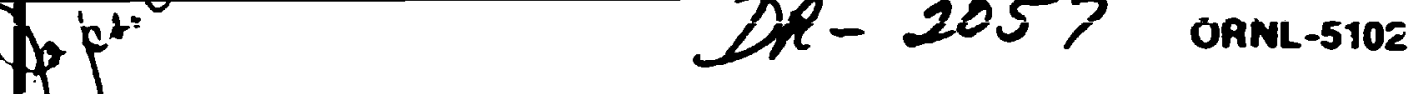

\title{
Zirconium Metal-Water Oxidation Kinetics I. Thermometry
}
J. V. Cathcart
D. L. McEiroy
R. E. Par al
R. A. Perkins
R. K. Williams
G. J. Yurek

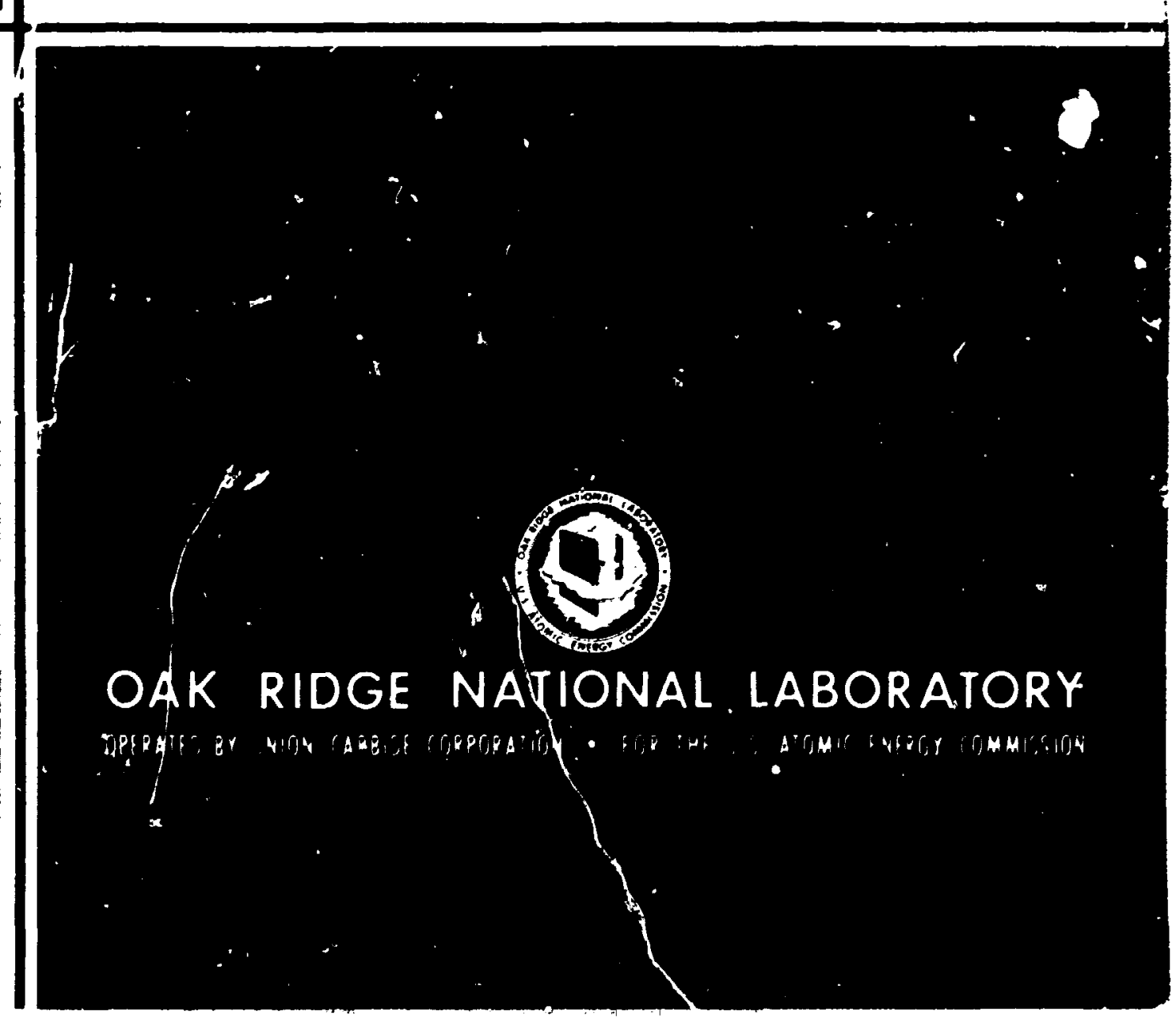




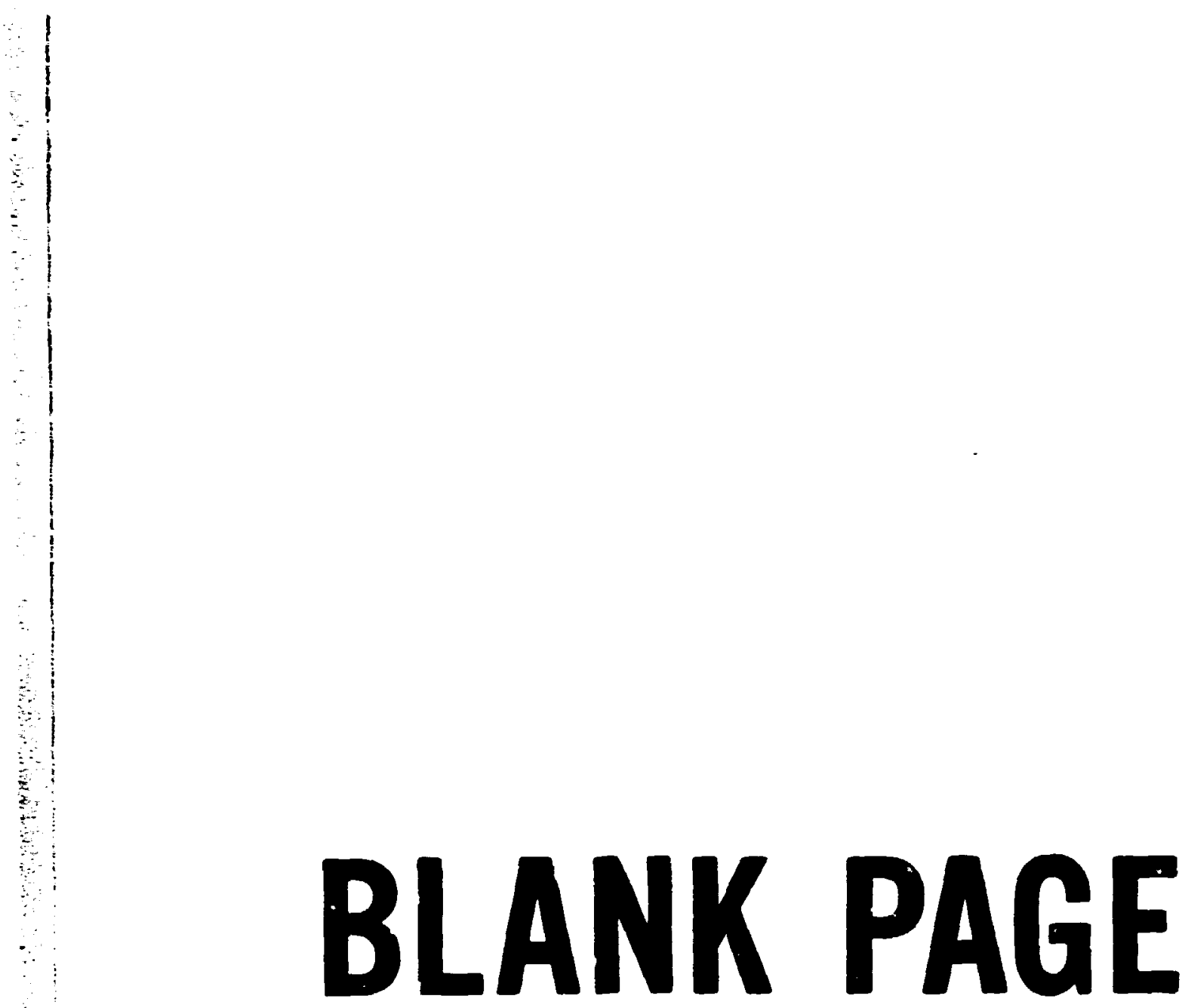




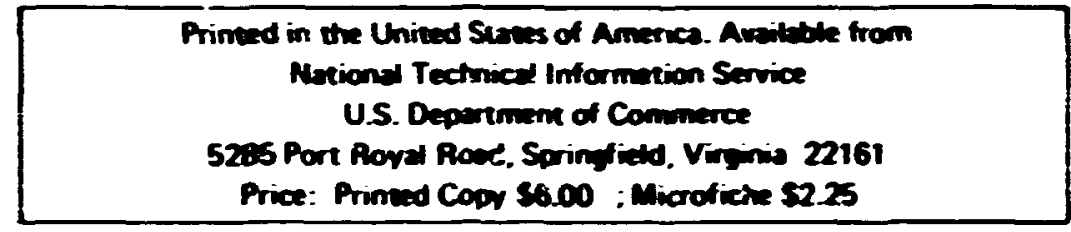

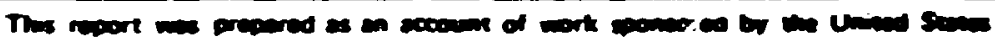

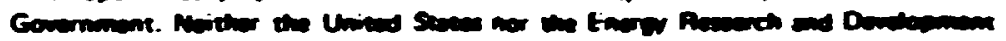

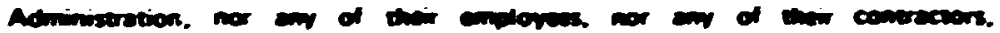

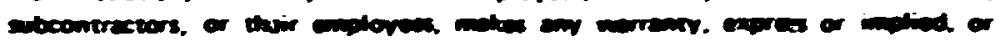

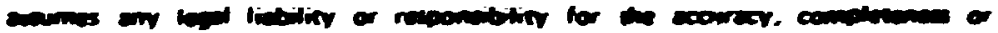

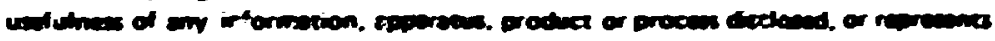

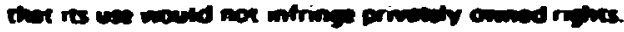


ait-5102

anc-1, -3

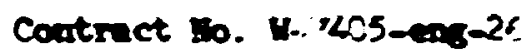

MidNS ND CERACS DTISIOK

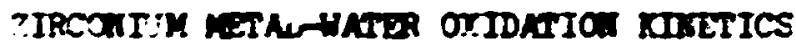

I. THERTDin?

J. P. Sathenrt, 2. L. Medros, R. E. Purel, R. A. Pertins, R. K. H1llian, and G. J. Turat

FEQNAN 1976

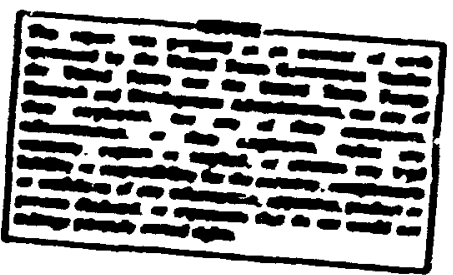

OAK RIDGE WALIOMAL LATORATOAY

Oak RIdge, Termessee 37830

coerated by

UNIOM CARBIDE CORPORATIOA

for the

U.S. EIERGY RESEARCH AND DEVELOPIDST ADMIIISTRATIOT 
antorss

ABSTRKC . . . . . . . . . . . . . . . . . 1

MrPoserion

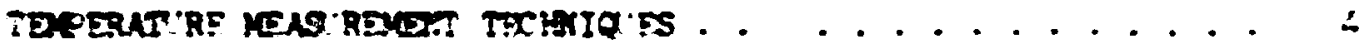

Therrocouple Salection and Celibration . . . . . . . . :

Therecouple-Specinen Compotibll1ty . . . . . . . . . r

optlenl Prroneter . . . . . . . . . . . . . . . L 1 ?

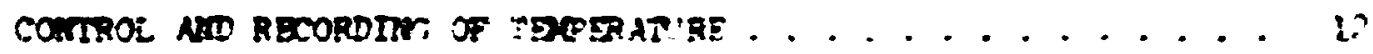

Aparetus Description............... 1?

Mint tor . . . . . . . . . . . . . . 13

matrox . . . . . . . . . . . . . I 1

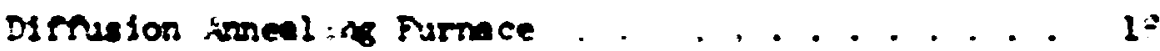

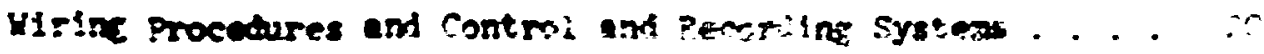

Anseling Pursace . . . . . . . . . . . . . . :

anszor . . . . . . . . . . . . . . 2

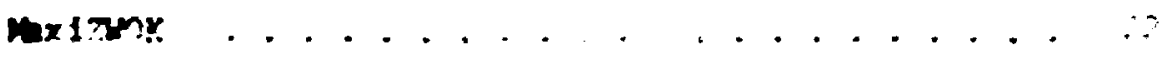

Tepereture Verip:tons urire Troeriaent. . . . . . . ?

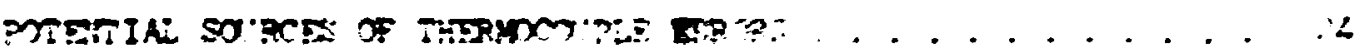

Thermal stanting . . . . . . . . . . . . . . . . . .

Inerwl Shanting in tise siniziny tpparstus . . . . . 3?

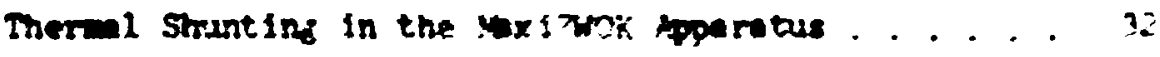

Difrueion Annealing popratids . . . . . . . . ?

gectrical Strunting ............... 3 . .

perasitic Be.s. . . . . . . . . . . . . . . 33

Dete toquisition Synten Error: ............. 36

Thernocouple Calibration Errors.............. 34

Tepersture srediente in tte sarpls............ 3

Decalibretion of Thernocouples ............ 38

Tob Attachnent Erfects . . . . . . . . . . . . . 36

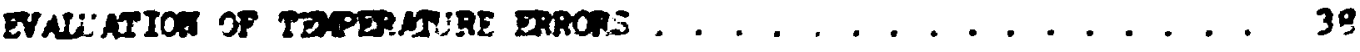

Doternisant errors . . . . . . . . . . . . . 38

Indeterndmont Exrors ............... 39 


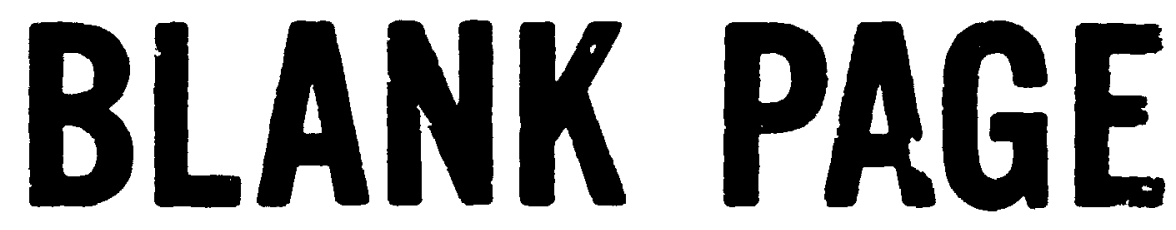




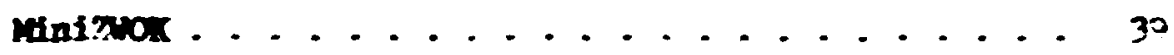

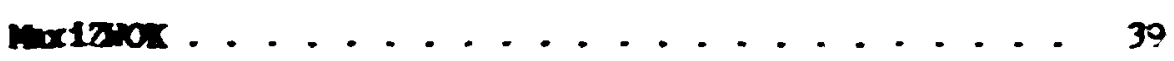

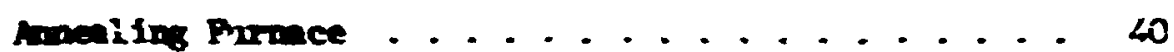

Total Error Butinte ................. 40

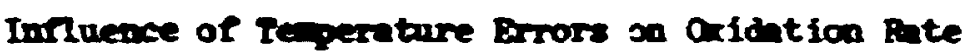

Constant Deteriortion .............. 45

concustas ........................ 40

Rerade. .................... 5

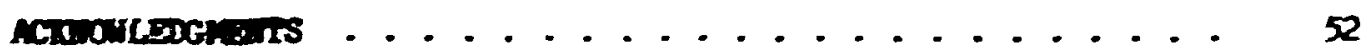

NPPLDD A . . . . . . . . . . . . . . . 53

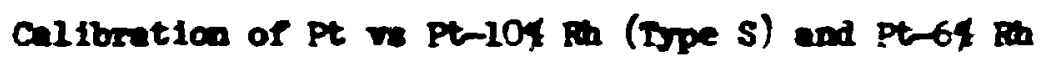

wat-30, Therecouples from 25 to $1500^{\circ} \mathrm{C}$

$\left(72732^{\circ}\right)$ !. . . . . . . . . . . . 53

Standarde .................... 56

Reqult. ................... 57

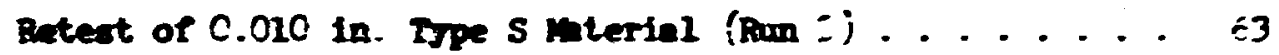

APEgDT B. . . . . . . . . . . . . . . . 67

Refermace Junstion syaten ............ 6T 
J. V. Catheart, I. L. Mellog, P. E- Purel, R. A Pertins, R. X. Willies, and s. I. Furel

retals and Cender Division Dnk Ridze Entioul Inboretory Dal Ridge, Temeasee $3783 \mathrm{C}$

\section{ABSIRLT}

This report describes the themonting technigues used in the Ifrconio retal-inter aridation Kinetics Frogle Teperetare mensarenents in the range 900 to $1500^{\circ} \mathrm{C}\left(1652-2732^{\circ} \mathrm{P}\right)$ are ade in thee experinental sjstem: bo axidntion apinrabises and the omealing furnece leet in a arollars stods of the

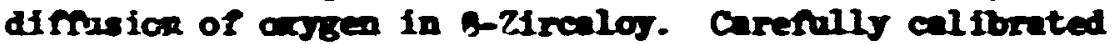

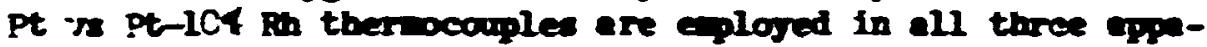
ratuses, vtile a Pt-6f $\mathrm{Fh}$ ve Pt-30/ Rh thernocouple and an ontion prronetar are used in addition in the arvealins nurmce. Features of the epperinentel system pertaining to thernocouple installation, tespereture control, ex weanrenents, etc. are described, and potential tenperntoure-measurenent error sources ere discussed in detall.

The eccurncy of our tepereture nenarenents is andred in ters of the deterinnt and indetendinat errors of the systen. We eatinte the probable abolute eccurnes of the

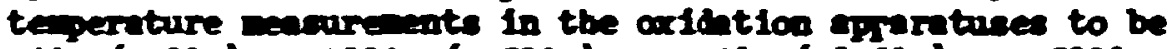
$\pm 4^{\circ} \mathrm{C}\left(7.2^{\circ} \mathrm{P}\right)$ at $900^{\circ} \mathrm{C}\left(1650^{\circ} \mathrm{P}\right)$ and $\pm 6^{\circ} \mathrm{C}\left(10.8^{\circ} \mathrm{T}\right)$ at $1500^{\circ} \mathrm{C}$ $\left(2732^{\circ} \mathrm{P}\right)$. In the worst case ve telleve that we can rpecif tenperature eccuretely to $\pm 10^{\circ} \mathrm{C}\left(18^{\circ} \mathrm{P}\right)$. For the ardealing nurmce the probable teperature orror aproud intes the deterninut errore for the ther ocouplea, $\pm 1^{\circ} \mathrm{C}\left(1.8^{\circ} \mathrm{T}\right)$ at $900^{\circ} \mathrm{C}\left(1 \in 52^{\circ} \mathrm{P}\right)$ and $\pm 2^{\circ} \mathrm{C}$. $\left(3.6^{\circ} \mathrm{F}\right.$; at $1500^{\circ} \mathrm{C}\left(2732^{\circ} \mathrm{F}\right)$. 


\section{ENDTHCTIO}

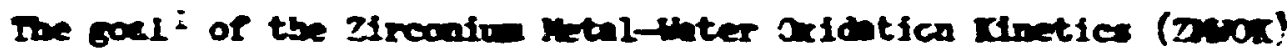

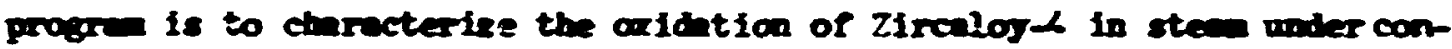

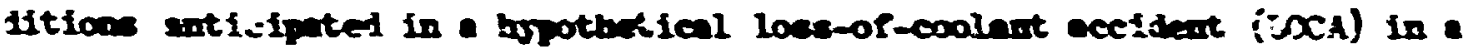
iIfht weter resctor. The rost consiote of two eqperiveatal tasks: 1) the neameneat of renction reted of Zirealos and sten under both isotherm and tramient teperatore condition and 2: the deteradintion of the

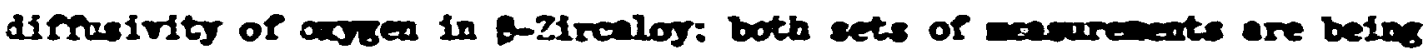
ete oner the temperatare range $9 x$ to $150 C^{\circ} \approx\left(1 \in 52-2932^{\circ} \mathrm{F}\right)$. In both

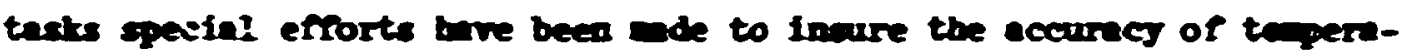
tare neararenents.

The iportance of boring the tegerature at which a gerinca is oxidising can be illnotrated by the rollaris calcalntion. The teperstire depeodence of the aridntion rate constant, k, for Ziralos is of the for

$$
x=A \exp (-Q / k x)
$$

where $A$ is a constant independent of temperature, $Q$ is the activation energs, $R$, the gen contant, and $T$ the tenperature in degreen keivin. Floure 1 shows the percentege changes in $k$ produced by errors in the sevared tepereture at verious nouinel test teperatures, asanding a velue of $30,900 \mathrm{~cm} /$ mole for Q. As discussed belor, the contraints ifposed by the experineatal necessity for meapuring the temeratare of a specinen imersed in floring sten can easily lead to $t$ - rature errors vell its excess of those shours in PIf. I and thus to unacceptably large departures ron the true vilue of $k$ at the noainal test temperatures. These results alke it easy to suppose that at least a part of the scatter in outidion data reported by previous workers is the to faulty tenperature measureant techniques, and it is obolous tbat every effort should be ande to minindze temereture errors, particularly systrsatic errors, it. all ruture work. 


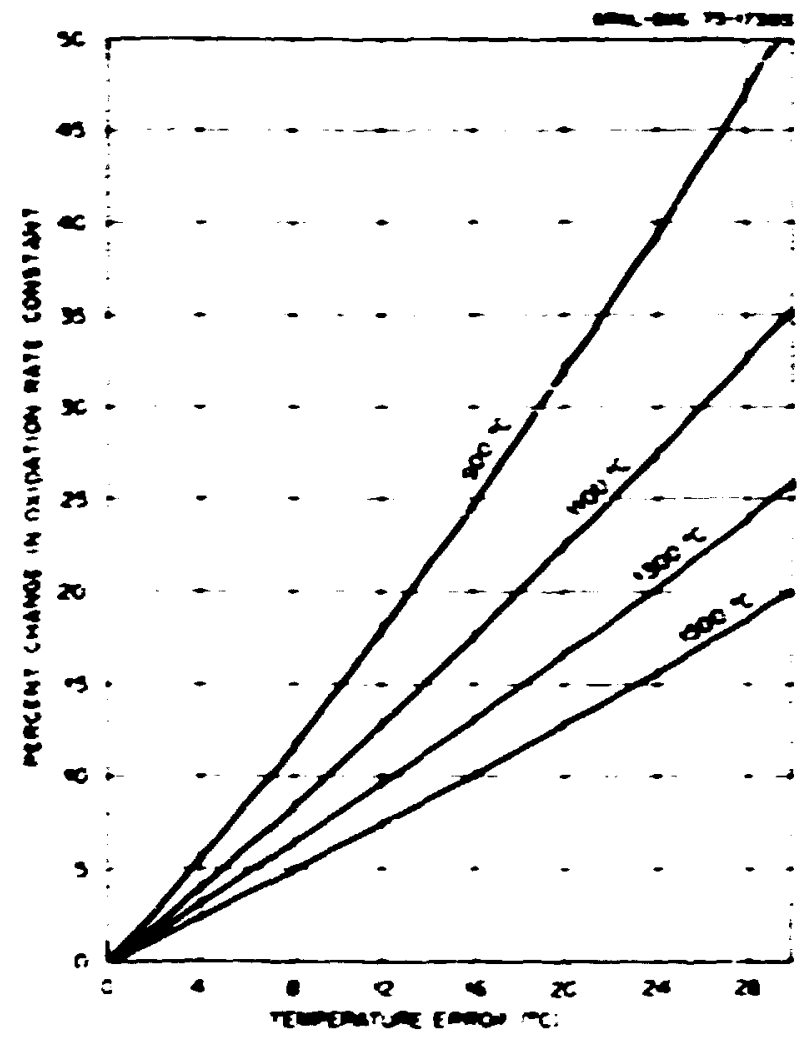

Fig. 1. Croses plot shouris percentage change in ariantion rete constant as a suction of teperature error at differeat teperabures.

A sindiar cavent is ppioprinte in diffusion stodiea in as ach as - difnision coefricient is also en exposential ranction of reciprocel tepereture. The technical probles of tespereture neavirenent during dirmution experinents are generalls easier to cope vith, boverer, in light of the fact thot difmation ameals are gewerally carried out in large, vell inoulated and shlelded furmces. Hostbeleas, care not be exerciaed.

This report is a deacription of the te pereture neasureneat problen excountered in the course of this progran and of the stepe taken to derine and elinimte or minindze sources of teperature error. 


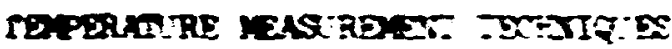

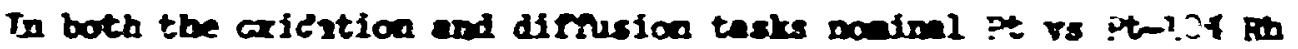
therocouples (tupe $s$ ! are used as our primer wans for deternining

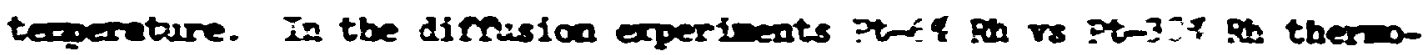
couples (t)pe E' are slo ettached to the specinens, end an optical prioneter is isec to obteis or eiditionl cbeck of the teperntire.

\section{Thernocouple Selection ast calitretion}

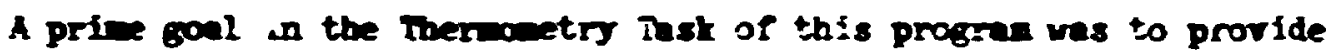

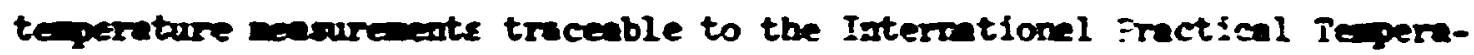
ture sale of $1 \% 9$ (rprs-es). In the tepereture range $\because$ to $155^{\circ} \mathrm{C}$ $\left(1 \leq 52-2732^{\circ} \mathrm{P}\right)$, the IPTS $6 \mathrm{f}$ is based on two instrunents: $(I)$ the Pt ve Pt-10e Ph thermocouple, wtalch spans the rarge $: 3: .-4$ to $1:=4.43^{\circ} \mathrm{C}$

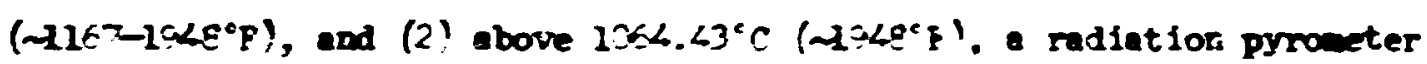

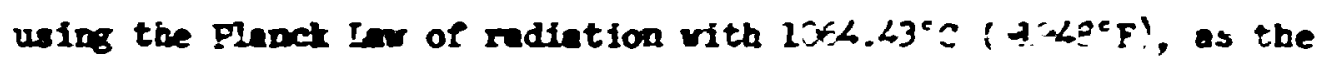
reference taperature and alue of $0.3143:=$ neter-kelvin for $\varepsilon_{2}$ in the matiance equation. ${ }^{2}$

For this resson auplies of platinu ond $\because-154$ Ris refererce grade thernocuple vire vere obtained from the Sigund Cohn Corporation." Indivitual lots vere fabricated from the same heat in order to ainfaize alibration differerces. The Pt-4.4 Rh and Pt-304 Rh sires vere ordered ron Mttbey Bisbop, Inc. " Several vire dianeters vere specified, but subsequent testing reveeled no difierences in the performance of thermo-

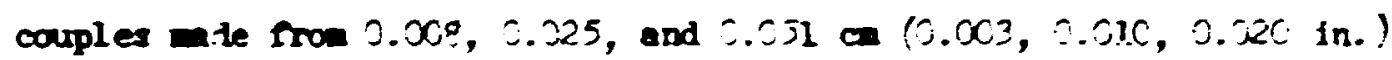
dian wires. Therefore, for the sake of case of hand ing, the $.0 .5 \mathrm{~cm}$ $(0.210$ in. ) dian wire vas used axclusively in all later experiments.

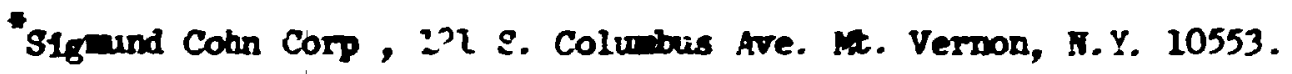
tutthey Bishop, Inc, Mivern, Pa. 19355. 
Prior to calibration all thermocxuple wires vere subjected to an air

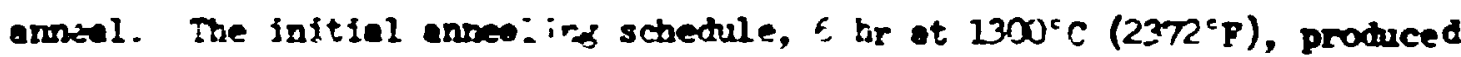
no difriculties with the pure platimn wire, but the tensile strength of the Pt-154 Rt was reduced by 304 and its total elopgation by 454. This deterioration of mechanical properties wes shown metallographically to be releted tc excessive grain growth in the vire huring the smseel: the -verage gre in size after anneal vos about bif the wire disneter. Therefore, a leas denodiag anneal ine schestile ves adopted: 2 an at

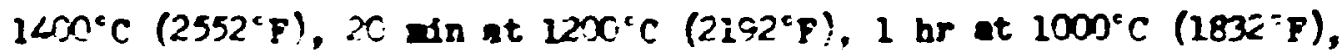
and ? hr ot $500^{\circ} \mathrm{C}\left(932^{\circ} \mathrm{P}\right)$. This treatment produred wires conposed of relativels sil, equiexed greins, and the nechnical properties of the vires vere not degreded.

The ectual celibretion of the verious thernocouple cominations ves carried out in the Mutrology Resenrch and Development Iaboratory, Instruzents and Controls Division, Oak Ridge Rational Laboratory. The procechure used imolved several caparison calitrations of the thersocoupies wites to $1500^{\circ} \mathrm{C}\left(2732^{\circ} \mathrm{F}\right)$. Several thermocouples, including two ras-culibreted Pt vs Pt-10 $\mathrm{Rh}$ thermocouples, vere corrected to a comon hot junction ard the eaf velues of various pafrs compared with the standards. A detailed description of the calibration procedure is given in Appendix A.

The date sbtaind indsceted thet the thernelectric properties of our vires vere excellent. The Pt vs $\mathrm{Pt}-104 \mathrm{Rb}$ wire behaved verg ach like the KBS-calibrated thernocouples, and calibration date for the Pt-64 Rh ve Pt-30 Rh thernocouples wes also obtalined. The terperetureanf relationabipe for the thernocouples are presented in the fpperdix.

This calibration procedure represents an attept to achiese, under ideal conditions, weasurements of teperature vith exinn uncertainty of $+2^{\circ} \mathrm{C}\left(3.6^{\circ} \mathrm{P}\right)$ on IPTS -68 at $1500^{\circ} \mathrm{C}\left(2732^{\circ} \mathrm{P}\right)$. Below $1064^{\circ} \mathrm{C}\left(1947^{\circ} \mathrm{P}\right)$, estimted uncertainties of therwocouple callbrations are less than $\pm 0.2^{\circ} \mathrm{C}\left(0.36^{\circ} \mathrm{P}\right)$ at fixed poirts and leas than $\pm 0.3^{\circ} \mathrm{C}\left(0.54^{\circ} \mathrm{F}\right)$ for table values between fixed points. ${ }^{3}$ These uncertainties increase above $104^{\circ} \mathrm{C}$ $\left(1947^{\circ} \mathrm{F}\right)$. At $1450^{\circ} \mathrm{C}\left(2646^{\circ} \mathrm{F}\right)$ en uncertainty of $\pm 1^{\circ} \mathrm{C}\left(1.8^{\circ} \mathrm{F}\right)$ is given 
for en NBS calibrated Pt vs Pt-10\% rin thermcouple, and we estimate an uncertainty of $\pm 1.5^{\circ} \mathrm{I}\left(2.7^{\circ} \mathrm{F}\right)$ ror $\mathrm{c}-\mathrm{s}$ thermocouples at $1500^{\circ} \mathrm{C}\left(2732^{\circ} \mathrm{F}\right)$. Thus our goal of an unsertainty of $\div 2^{\circ} \mathrm{C}\left(3.5^{\circ} \mathrm{F}\right)$ at $1500^{\circ} \mathrm{C}\left(2732^{\circ} \mathrm{F}\right)$ eppears realizable except for possible problems associated with thermocouple decrlibration during installation end use.

We addressed this latter concern by submitting for recalibration a Ft vs Pt-10\% $\mathrm{Rh}$ thermocouple that had been used in various experiments between 900 and $1475^{\circ} \mathrm{C}\left(1652-2587^{\circ} \mathrm{F}\right)$ for approximately $3 \mathrm{hr}$. This thermocouple was tested to $1000^{\circ} \mathrm{C}\left(1532^{\circ} \because\right.$ !, and the results of the recalibration (see sppendix) give no evidence of decalibration problews. - Portions of a similar thermocouple were also submitted for chemical analysis (seo Table 1 ). There was no indication of significant contamination which might lead to decalibration of the thermocouples.

A feature of our experimental procelure that mitigates decalibration difficulties is the fact that in a normai experiment the tissrmocouple hot junction is made by welding the thermocouple leads to a small tab of tantalum that is in turn welded directly to the specimen. At the end of an experiment the leads are clipped off just below the hot junction, and an entirely new hot junction is firmed on the next specinen. Thus any contaminants near the hot junction are eliminated before chey have time to dirfuse far erough along the thermucouple wires to produce problems.

\section{Thermocouple-Specimen Compatibility}

The Zircaloy-steam reaction is righ exothermic ( $\Delta \mathrm{H} \approx 140 \mathrm{k} \mathrm{cal} / \mathrm{wole}$ in the temperature range of interest), and significant self-heating of a Zircaloy specimen can occur under conditions where the rate of oxidation is high. Therefore, in order to monitor accurately the temperature of an oxidizing sample, we considered it essential that metal-to-metal contact be malutained at all times between the speciwen and the thermocouples.

Unfortunately platinum-base thermocouples cannot be attached directly to 7,1rcaloy specimens used in experiment.s aiove $\sim 1150^{\circ} \mathrm{C}\left(2102^{\circ} \overrightarrow{\mathrm{F}}\right)$ because of the formation of a low melting $\left[1285^{\circ} \mathrm{C}\left(2165^{\circ} \mathrm{F}\right)\right]$ Pt-7r eutectic 
Table 1. Zpectroscopic Analysis of Pt vs Pt-lOq Rh Thermoccuples

\begin{tabular}{|c|c|c|c|c|c|c|c|c|}
\hline \multirow[t]{2}{*}{ Fiement } & \multicolumn{8}{|c|}{ Analysis, ppm by wt, at positions } \\
\hline & 1 & 2 & 3 & 4 & 5 & $\epsilon$ & 7 & $g$ \\
\hline $\mathrm{Al}$ & $?$ & 2 & 2 & 0.5 & $\varnothing .1$ & 0.1 & 0.1 & 0.3 \\
\hline $\mathrm{E}$ & 0.4 & 0.4 & 0.3 & 0.3 & 1 & 0.3 & 0.4 & 0.3 \\
\hline $\mathrm{Ca}$ & 0.5 & 0.3 & 0.3 & 0.3 & 0.3 & 0.3 & 0.3 & 0.3 \\
\hline C. & 50 & $\infty .5$ & 0.5 & -1.5 & $\infty .5$ & $\varnothing .5$ & $\varnothing .5$ & 4.5 \\
\hline $\mathrm{Cr}_{r}$ & 0.5 & $\varangle .2$ & 1 & 0.5 & 0.5 & 0.5 & 0.5 & 0.5 \\
\hline $\mathrm{Cl}$ & $?$ & 7 & 10 & 5 & 7 & 3 & 7 & 5 \\
\hline $\mathrm{Cu}$ & 300 & 7 & 20 & 0.7 & 7 & 0.7 & 7 & 0.7 \\
\hline $\mathrm{Fe}$ & 50 & 20 & 20 & 5 & 20 & 5 & 50 & 3 \\
\hline $\mathbf{K}$ & $\infty .5$ & $\infty .5$ & $\infty .5$ & 0.2 & $\$ .5$ & $\infty .5$ & $\infty .5$ & $\infty .5$ \\
\hline$M$ & $\leq 0.5$ & $\leq 0.5$ & $\leq 0.5$ & $\leq 0.5$ & $\leq 0.5$ & $\$ 0.5$ & $\leq 0.5$ & $\leq 0.5$ \\
\hline $\operatorname{Mn}$ & 0.5 & $\infty .1$ & $\infty .1$ & $\infty .1$ & $\infty .1$ & $\infty .1$ & $\infty .1$ & $\infty .1$ \\
\hline $\mathrm{Na}$ & $\varnothing .5$ & $\infty .:$ & $\infty .5$ & $\Phi .5$ & $\varnothing .5$ & $\infty .5$ & $\infty .5$ & $\infty .5$ \\
\hline $\mathrm{Ni}$ & 7 & 3 & 3 & 0.2 & 3 & 0.2 & 5 & 0.2 \\
\hline$P$ & $\infty .5$ & $\infty .5$ & $\infty .5$ & $\varnothing .5$ & $\varnothing .5$ & $\infty .5$ & $\infty .5$ & $\varnothing .5$ \\
\hline $\mathrm{Pb}$ & 1 & $<$ & 5 & 4 & 4 & 7 & 4 & 4 \\
\hline $\mathbf{P d}$ & 1 & $\infty .5$ & $<.5$ & 0.5 & 3 & $\infty .5$ & ن. 5 & $\infty .5$ \\
\hline Pt & $M$ & $M$ & $\mathbf{M}$ & $\mathbf{M}$ & M & $M$ & $\mathbf{M}$ & $\mathbf{M}$ \\
\hline Rh & $M$ & $M$ & & & $\mathbf{M}$ & & $\mathbf{M}$ & \\
\hline $\mathrm{Sb}$ & 5 & 1 & 10 & 3 & 5 & 3 & 3 & 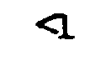 \\
\hline$S i$ & 3 & $?$ & 7 & 7 & 10 & 10 & 10 & 7 \\
\hline $\mathrm{Ta}$ & $\leq 1$ & $\leq 1$ & 53 & $S I$ & $s 1$ & s?. & $\Omega$ & $\leq 1$ \\
\hline $\mathrm{Ti}$ & $Q$ & 8 & 2 & 2 & 2 & 2 & 2 & $R$ \\
\hline$v$ & $\infty .1$ & $\infty .1$ & $\infty .1$ & $\infty .1$ & 0.1 & $\infty .1$ & $\infty .1$ & $\infty .1$ \\
\hline 7.1 & 5 & $<3$ & 7 & 5 & 3 & $\infty .5$ & $\infty .5$ & $\infty .5$ \\
\hline
\end{tabular}

Position 1: Pt-10\% Rh wire adjacent to hot function.

Position 2: Pt-10\% Rh wire at break between double ard single bore insulation just below bottom of specimen.

Position 3: Same as position 1 except Pt wire analyzed.

Position 4: Same as position 2 except pt wire analyzed.

Position 5: Pt-10\% Rh wire at point where thermocouple exited flimace.

Position 6: $\quad \mathrm{P}^{\prime}$ wire at point where thermocouple exited furnace.

Position 7: Pt-10\% Rh control sample (annealed, as-received wire).

position 8: Pt control sample (annealed, as-received wire). 
(see Fig. 2.). We circumented this problem by inserting tantalum or iridium tabs $[2 \times 2 \times 0.075(0.08 \times 0.08 \times 0.003$ in. ' $]$ between the thermocouple and the spicimen. The thermocouple leads were first spot welded to tab with the ends of the leads separated by a distance of about $0.25 \mathrm{~mm}(0 . \mathrm{Gl}$ in.), and the tabs were then spot velded to the specimen. The subsequent discovery of thermal gradients in the MinizwoK oxitation apparatus (see belor) led to a modification of the pruceture in that the ends of the thermocouple leads were velded directly together on the tar so as to minimize the width of the hot junction.

\section{Pt-Zr Platinum-Zirconium Y-135220}

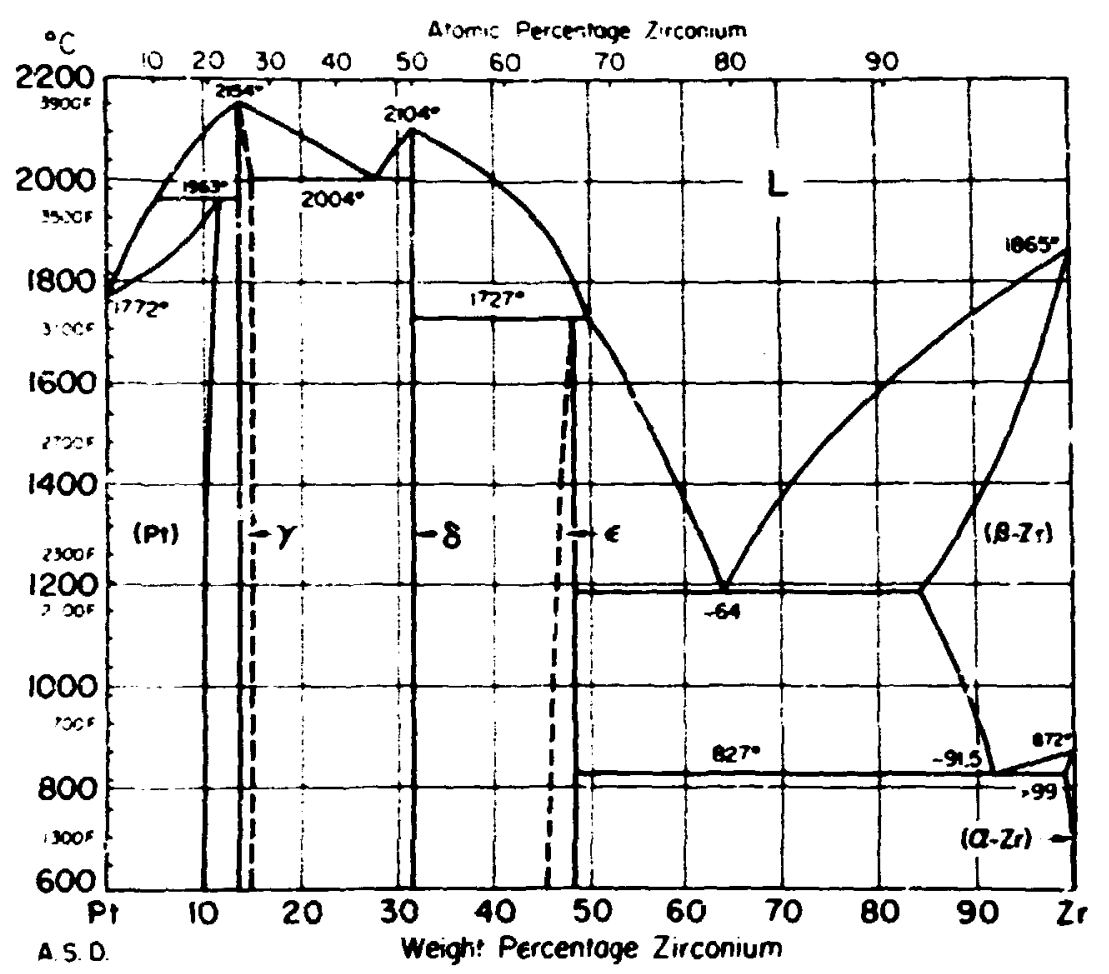

Fig. 2. Platimum-7,irconium phase diagram after Hawkins and Hultgren. 4 
Tantalum proved to be an e.sellent tab material when used in vacuun, as in our diffusion experiments, or in an inert gas, as in our low therwal inertia cxidation apparatus (see below). A $\mathrm{Zr}-\mathrm{Ta}$ eutectic melting at $\sim 1850^{\circ} \mathrm{C}\left(3362^{\circ} \mathrm{F}\right)$ has been reported ${ }^{5}$ but prodiced no problems. A narrow diffusion zone between a tais and a Zircaloy diffusion specimen could be detectea after a 30 min anneal at $1450^{\circ} \mathrm{C}\left(2642^{\circ} \mathrm{C}\right)$, Fig. 3, bit because the function between tab and specimen always consisted of metal vith good thermal condictivity, we see no reason to question the validity of this form of thermocomple attachment. No Pt-Ta phase diagram appears to ke available, but metallographic exarinarions of the Pt-To interfac: showed no sien of interaction. The only disadvantage of the tantalum tabs was the necessity to protect them from steam during our aridation experiments.

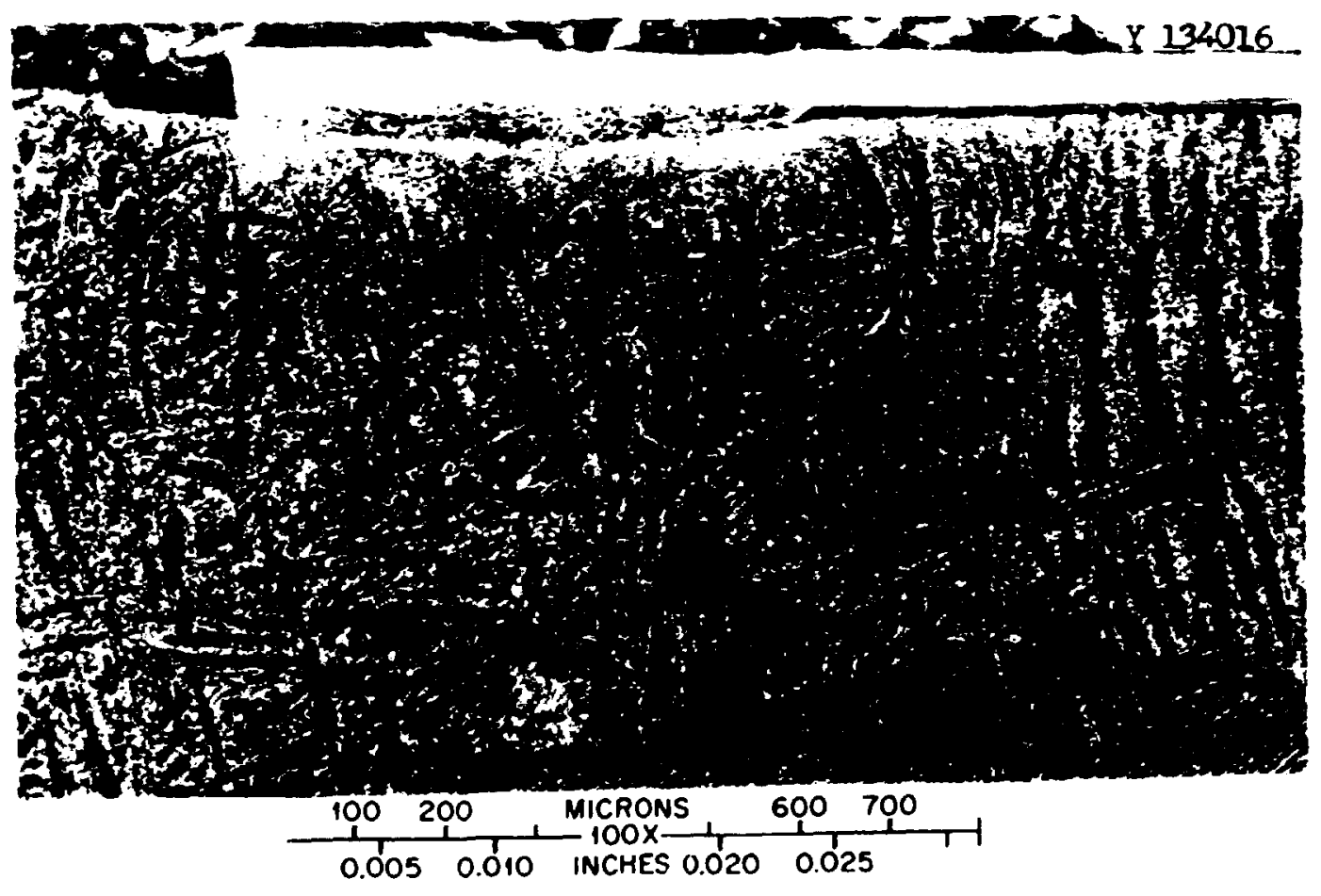

Fig. 3. Cross section through tantalum thermocouple tab spot relded to Zircaloy 4 difnsion specimen. Specimen was annealed in vacuum for 30 min at $1450^{\circ} \mathrm{C}\left(2642^{\circ} \mathrm{F}\right)$. 
Because it is much more difficult to protect the therwocouple tabs in our second oxidation rate apparatus (see beior), we amployed sridiun tabs for use in stean where, in the temperature range of interest, iridiun is inert. He vere unable to find a $\mathrm{Zr}$-Ir phase diagram in the literature, and preliminary annealing tests ${ }^{1}$ in vacuum did indicate the formation of a $\mathrm{Zr}$-Ir elitectic between 1200 and $1300^{\circ} \mathrm{C}\left(2192-2372^{\circ} \mathrm{F}\right)$. However, in these tests the spocimen was heated at a rate of $400^{\circ} \mathrm{C} / \mathrm{hr}\left(720^{\circ} \mathrm{F}\right)$, thus providing ample time for interdiffusion between the sample and tab. In a much shorter test, in wich a temperature of $1400^{\circ} \mathrm{C}\left(2552^{\circ} \mathrm{F}\right)$ was realized, carried out under the ijme-temperature regime show in Fig. 4, tbe thermocouple did remin attached to the specimen throughout the experiment. Subsequent metallograpic examination of the specimen (Fig. 5) shower eviaence of liquation in both the tab and the specimen.

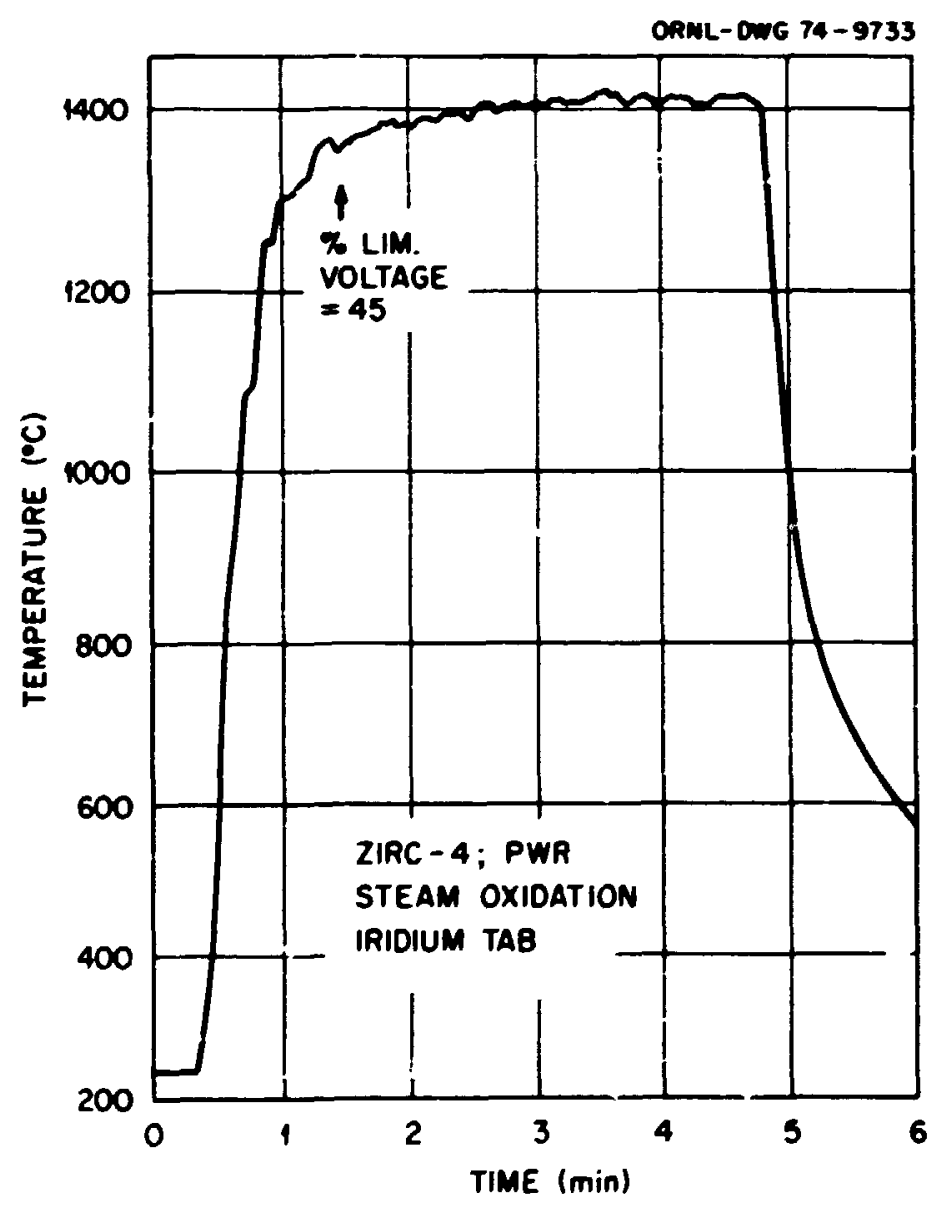

Fig. 4. Recorder trace of time-temperature regime used in test o? iridiun thermocouple tab on Zircaloy-4. 


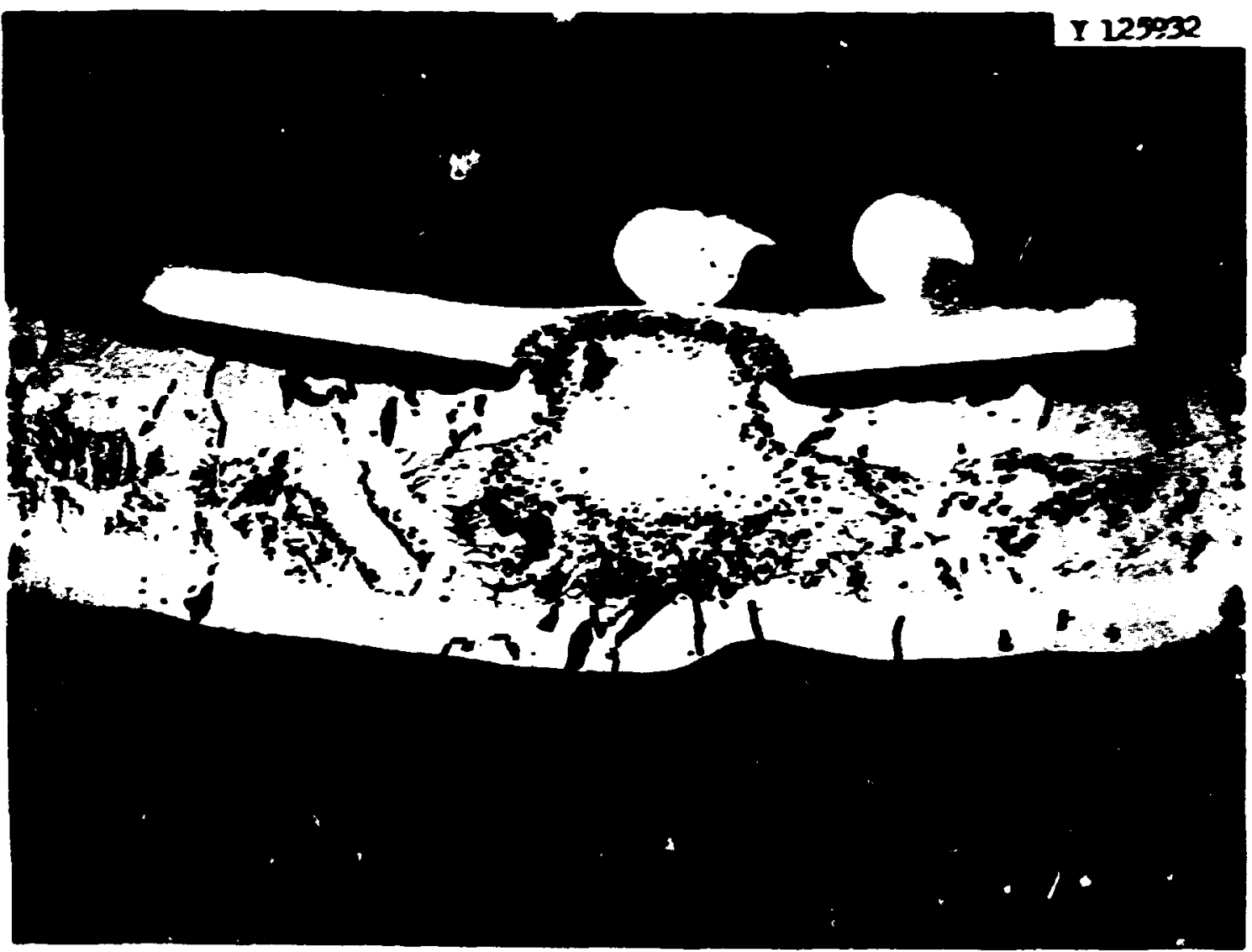

F's. 5. Cross section of Zircalog-4 Fin tube specinen efter expoure in stean according to the teperature cjele of F16. 4.1. Ninntrates interaction zone associnted with weid between iridiw tab fon inside of tube) and specinen. As polisbed, brigbt Field, 62x.

Hewerer, selting was conflined to the badinte ricinity of the tab, the tib itself wes not penetrated (thus protecting the thernocouple lade ron attack), and good physical and therenl coatact was mintaioed between the tab and specinen throughout the aperinant. For thece reacons and becmuse ve asticlpate oxidation experinecte of duratioas

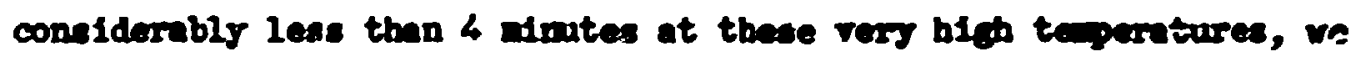
are confidont thet iridiun tabe can be used successhully as noodod in our aridation rate studies. 


\section{Optical Pyrameter}

Two optical psroneters vere used in our difhusion studies. The rirst, aviliable to us on an internittent besis, was a Pyraneter Instrumeat capary photoelectric prraneter which was calibreted relative to IPIS-68 using two IBS-certified gas-filled ungsten strip larps. During the course of calforstion and in subsequent periodic checks egainst an IX vecum tungsten strip larp, sall shifts [generally less than $\left.1^{\circ} \mathrm{C}\left(2.8^{\circ} \mathrm{F}\right)\right]$ were noted in the pyrometer readings. These changes were atributed to a slight drift in the pyraneter reference lanp, and a systentic record of these shifts has been wintained so that these additiom an all corrections can be made in the pyrometer readings between ajor recalibrations. The tutal error ${ }^{6}$ associated with the use of this instrunent raries somerbat with temperature; at the gold point $\left[1064^{\circ} \mathrm{C}\left(1947^{\circ} \mathrm{P}\right)\right]$ the error is $\pm 1.7^{\circ} \mathrm{C}\left(3.1^{\circ} \mathrm{F}\right)$; at $1500^{\circ} \mathrm{C}\left(2732^{\circ} \mathrm{F}\right)$ it is $\simeq 3^{\circ} \mathrm{C}\left(5.4^{\circ} \mathrm{P}\right)$.

The second pyrometer used was a Pyrometer Instrument Company vicro optical pirometer, mamully balanced. This pyrometer was callibrated to $1300^{\circ} \mathrm{C}$ using an VBS vacuum tungsten strip lamp. The instrument readibility error resulting from this procecture was $\pm 2^{\circ} \mathrm{C}$ $\left(3.6^{\circ} \mathrm{F}\right.$ ), an error which is a part of the total instrument error (see Table 4, page 421 .

\section{COMTRCL AND RECORDING OF TEMPERATURE}

Three different apparatuses in which temperature measurements are required are belng used in this program: an annealing furnace for the difrision studies and two oxidation rate apparatuses that we heve named "MinizwOr" and "MaxizwOR." In all three cases the design of the units was considerably influenced by the need to create experimental conditions under which temperature could be messured accurately, controlled properly, and recorded in an adefiute manner. In this section we give description of the apparatuses and of the associated wiring, crintrol, sid recording systems. 
Apparatus iescription

vinizior

The Minizion apparatus is a low thers inertia device used in the neasurement of isotherial rates of axidntion and in controlled 1.ransient terperature experiments. It is shown schestically in PHg. 6. The reaction chamer consists of a $60=$ (2.36 in.) 0.D. quarts tube $50 \mathrm{~cm}$ (23.6 in.) long with a Zircalog 4 PWR tube specinen [30 a Ioag by $10.7=0$. D. by $9.3=$ I.D. (1.18 $0.42 \times 0.37$ in. $)]$ supported at its center between two anller quartz tubes. During an experinent stean flows past the outside surface of the specinen, and a slight pasitive pressure of heliun is aintained inside the support tubes in order to prevent egress of stean to the interior of the specinen. A helium nor rate of $0.2 \mathrm{cc} / \mathrm{sec}$ is used for this purpose.

The specimen is instrumented with three Pt vs Pt-10/ Rh ther.ocouples. As descrived earlier, the bot junctions are forned by spot welding the thermocouple leads to small tantalun tabs $[2 \times 2 \times 0.075=(0.08 \times 0.08 \times$ 0.003 in. )] that are in turn welded to the interior of the sapple near its midpoint. One thernocouple is connected to the te-perature controller, and the other two are used as measuring couples. In sone expertments a separate tab was used for each thersosouple, but the wre aroul arrangenerst is to attach the control thernocouple and one neasuring couple to a single tab and to position the second ncasuring couple on another tab mounted diametrally opposite the pirst.

This Beneral design was adopted so that the therrocouple tab could be protected from the steam and also to ninindse thernil sbunting effects. The latter purpose is also served by the tantalu bat shield inserted into the upper portion of the opecinen. A lower beat shield is formed by the ends of the double-bore, Decussit AL-23, high-purity aluaten inoulators used to separate the lower portions of the thersocouple leads. The upper parts of insulators are within the furnce and alco serve to prebeat the heliw before it ranches the interlor of the procinen. 


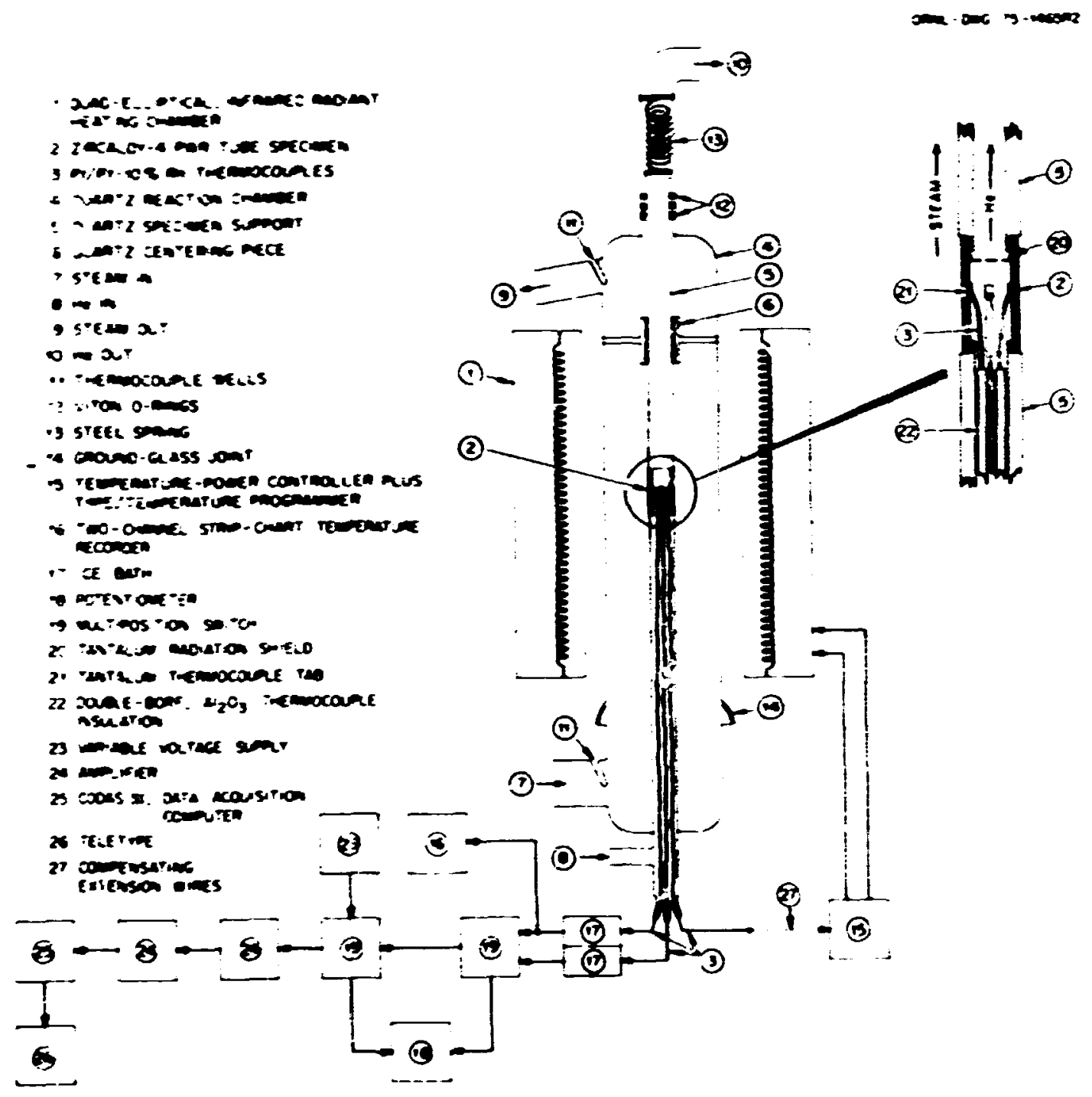

P18. 6. Schemtic dingen of the Hiniziok oridation epparatuc.

The furnace surrounding the reaction charber is a Resenrch, Inc. quad-elliptical radiont bating chaber, rodel $\mathrm{E}$ h, with a bot sone of $25.4 \mathrm{c}$ (10 in.). Heating rutes of $150^{\circ} \mathrm{C} / \mathrm{sec}\left(270^{\circ} \mathrm{F} / \mathrm{sec}\right)$ or higher can be attained with this unit, and the response of both the surnace and Ite controlier is very rust. These characterietics plus the ract that the surnece is controlled directly by the spection tementure prevent 
specimen over-hea+ing and allow iscthermal conditions to be mintained during oxidation. A typical time-temperature recorder trace is shown in Fig. ?.

MarizWOK

This -xidation rate apparatus is show schematically in Fig. 8. It differs from MiniTwOK in that the steam is prebeated [max temp: $\left.-1000^{\circ} \mathrm{C}\left(1932^{\circ} \mathrm{F}\right)\right]$ end the steam and furnsce timperatures are controlled and fixed during an experiment. The specimen temperature is allowed to Iloat, being determined by the combiration of furnace and steam temperatures and stean flow rate. The latter is estimated to be $-80 \mathrm{~km} / \mathrm{hr}$ (50 mi/hr) in most experiments. This corresponds to steam flow rates of $\sim 1 \mathrm{lb} / \mathrm{min}$.

The steam temperature is measured by a Pt vs Pt-10\% Rh thermocouple suspended in the steam at the top of the ceramic reaction chamber. The reaction chamber is heated directly by a tubular resistance furmace whose temperature is measured by a stainless-steel sheathed Chromel-Alumel thermocouple inserted into the $0.3 \mathrm{~cm}(0.12 \mathrm{in.})$ wide anmulus betwi:an the furnace wall and the reaction tube.

The specimen is a $46 \mathrm{~cm}$ (18 in.) length of Zircaloy tubing. A serles of ventilation slots is cut into the lower portion of the specimen to allow free flow of steam through the intert.or of the tube and to reduce heat conduction from the upper end of the bube io its cooled lower end. The specinen is instrumented with three Pt vo Pt-10\% Ph therwocouples welded to the outside of the tabe, $120^{\circ}$ apart at a point $5 \mathrm{~cm}$ (2 in.) from the upper end.

The inotruneated ppecinen is mounted atop the plunger of a il bydraulic ra located in a distilled-water quesch bath fust belor the reaction chamber. Once the desired rurnce and otcan tenperstures and the appropriate sten hor rate have been attainod, the apecinen is driven up Into the reaction chaber in 4 exc. At the and of the copperinant the angle is aonin lowered in 4 sec into the quench batb. A typical timteperature record is shom in F18. 9. 


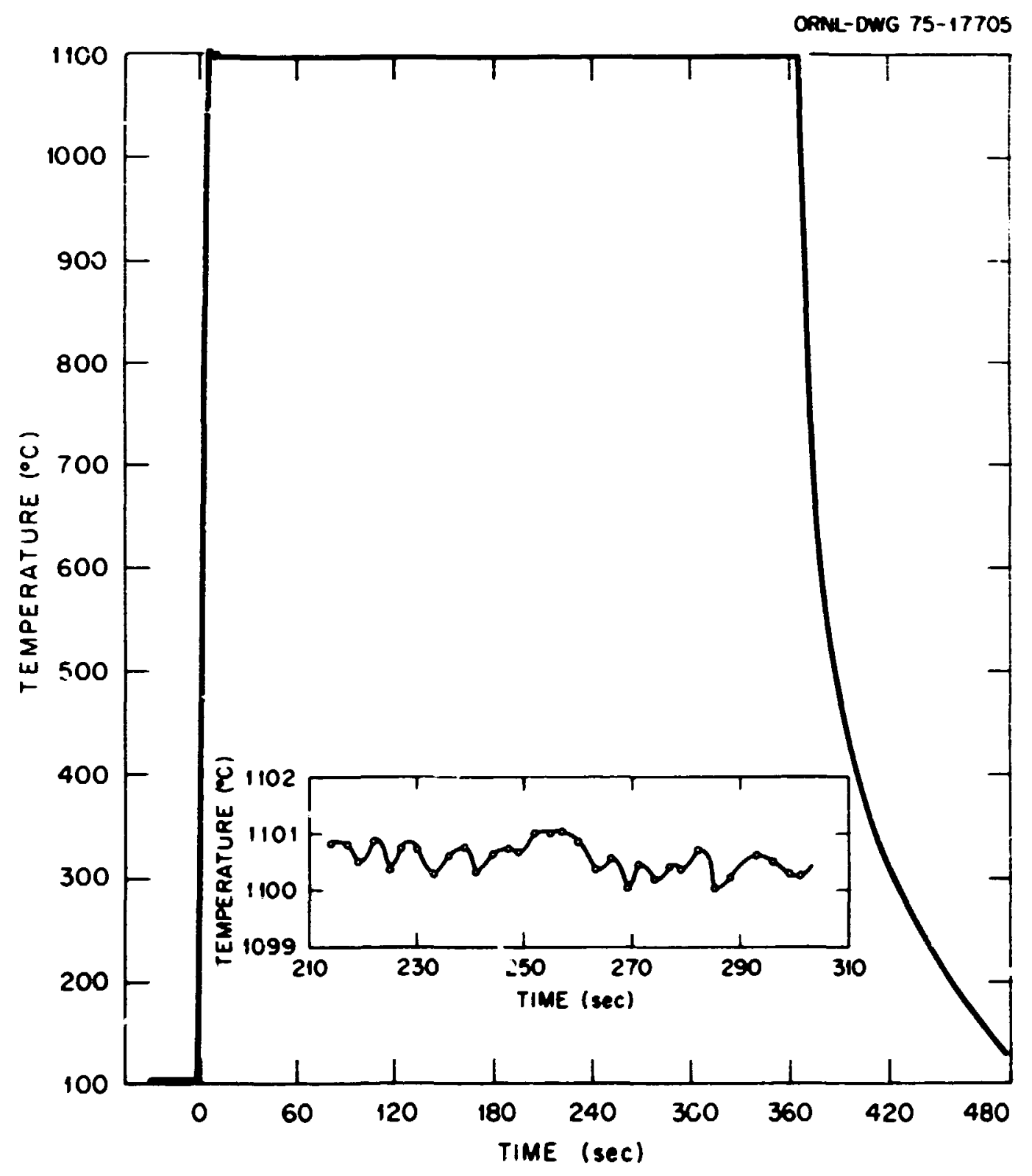

Fig. 7. Recorder trace of time-temperature record for a typical MAniZWOK experiment at $1100^{\circ} \mathrm{C}$. Inset shows rine scale temperature Ructuation as recorded by CODAS. 


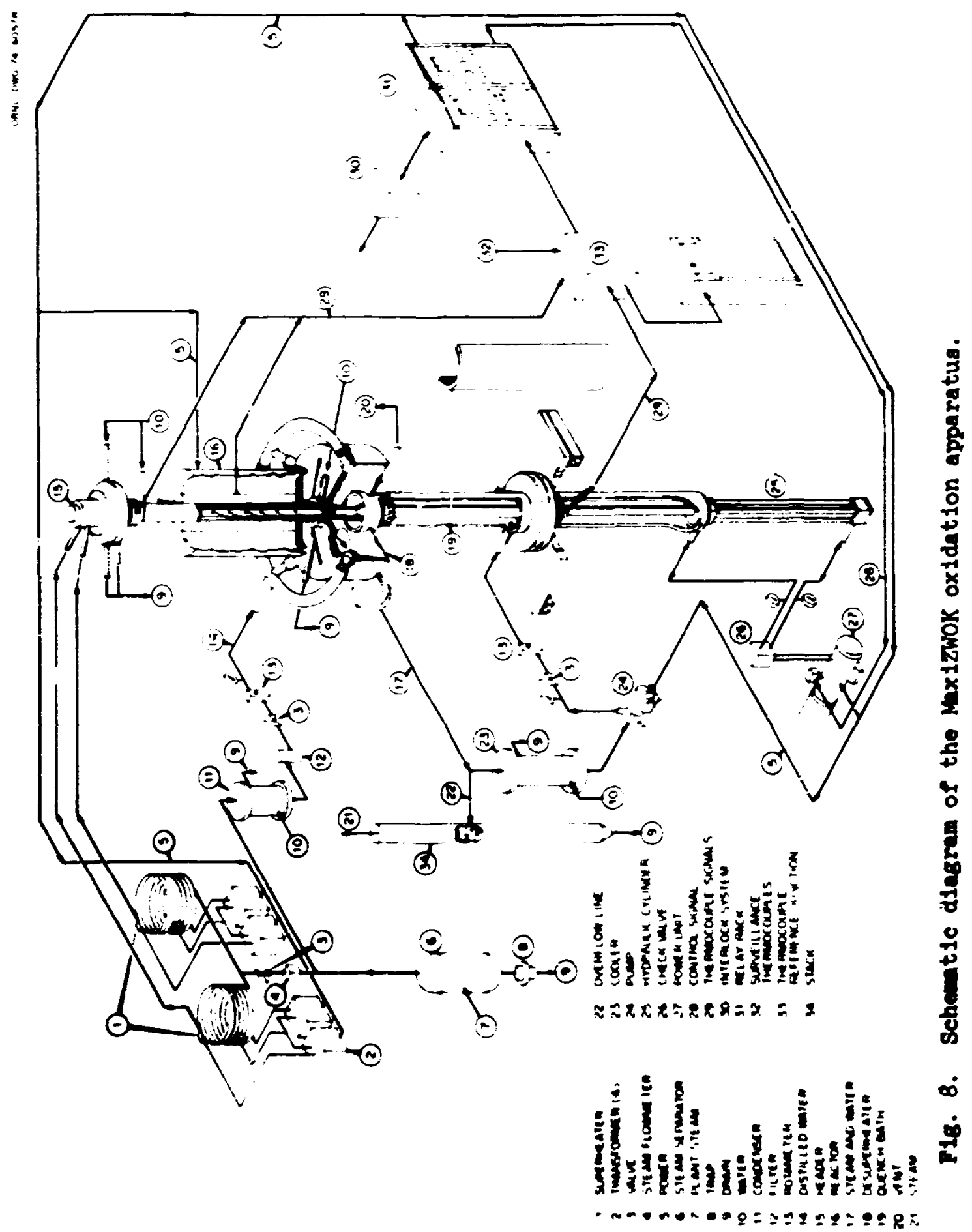




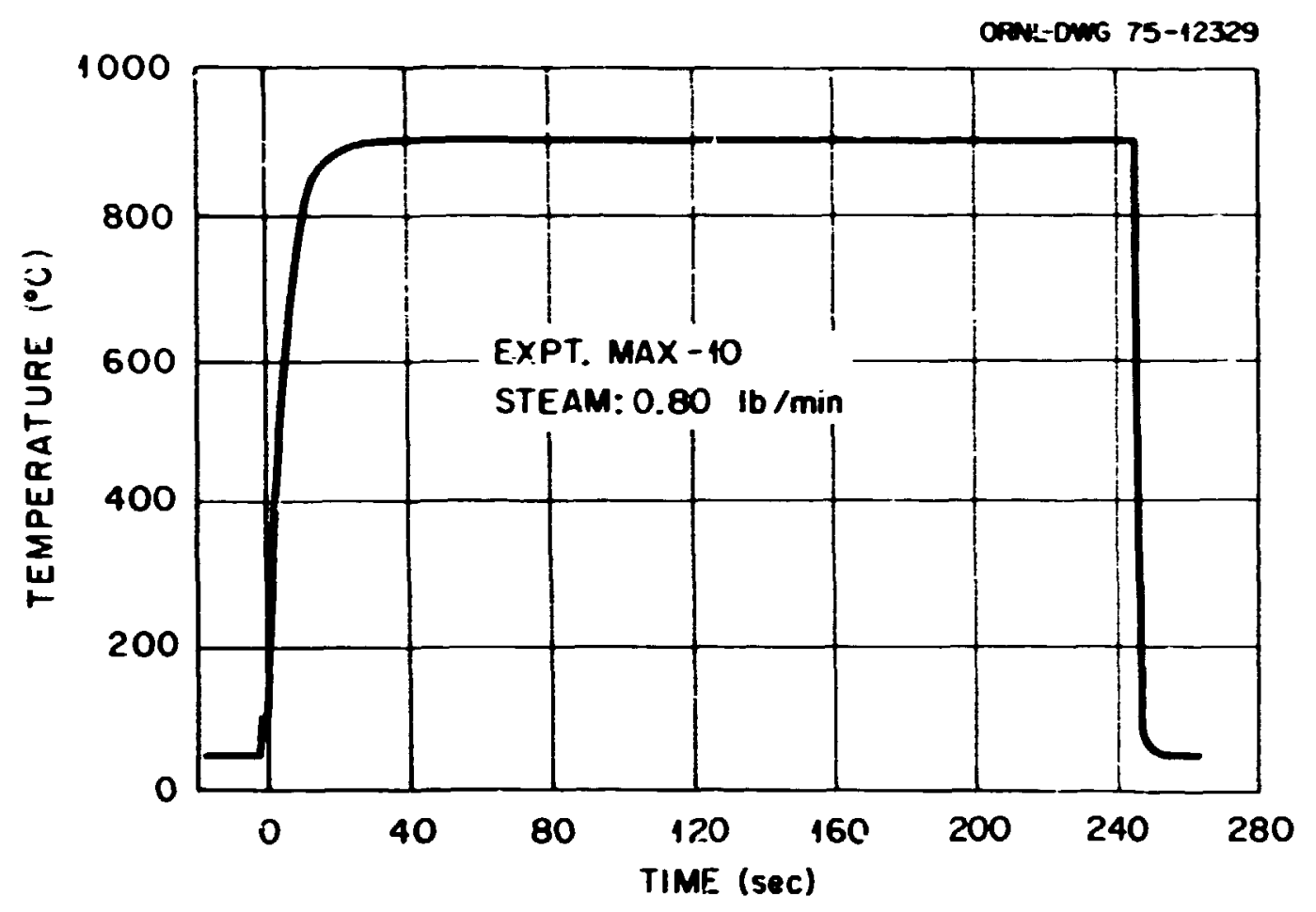

Fig. 9. Specimen temperature as a function of time for a MaxizWOK oxidation experiment at $900^{\circ} \mathrm{C}\left(1652^{\circ} \mathrm{F}\right)$.

\section{Diffusion Annealing Furnace}

A tantalum split-shield furnace is used for the diffusion anneais (see Fig. 10). The specimens; which are Zircaloy disks, $11 \mathrm{~mm}(0.43 \mathrm{in.})$ in diam and 4 to $7 \mathrm{~mm}(.16-.2 \varepsilon \mathrm{in}$.$) thick, are instrumented with two$ $\mathrm{Pt}-6 \% \mathrm{Rh}$ vs $\mathrm{Ft}-30 \% \mathrm{Rh}$ and one Pt vs Pt-10\% $\mathrm{Rh}$ thermocouples welded to tantalum tabs attached along the circumference of the specimens. One of the Pt $6 \%$ Rh vs Pt-30\% Rh thermocouples is used to control the furnace temperature, and the other two are measuring couples.

The specimen is located on a tantalum pedestal the center of the tantalum split-shield heating element that is resistively heated. Multiple tantalum heat shields completely surround the furnace except at the top where an $8 \mathrm{~m}(0.3 \mathrm{in.})$ diam bole provides optical access to a small crystal-bar zirconium cylinder [6 mm diam $\times 10 \mathrm{~mm}(.24 \times .39 \mathrm{in.}) \mathrm{high}$ ] positioned on the pedestal imediately adjacent to the diffusion specimen. A $1 \mathrm{~mm}(0.04 \mathrm{in.})$ diam hole crilled $8 \mathrm{~mm}(0.32 \mathrm{in.})$ deep into the top 
ORNL - OWG 74-5742R

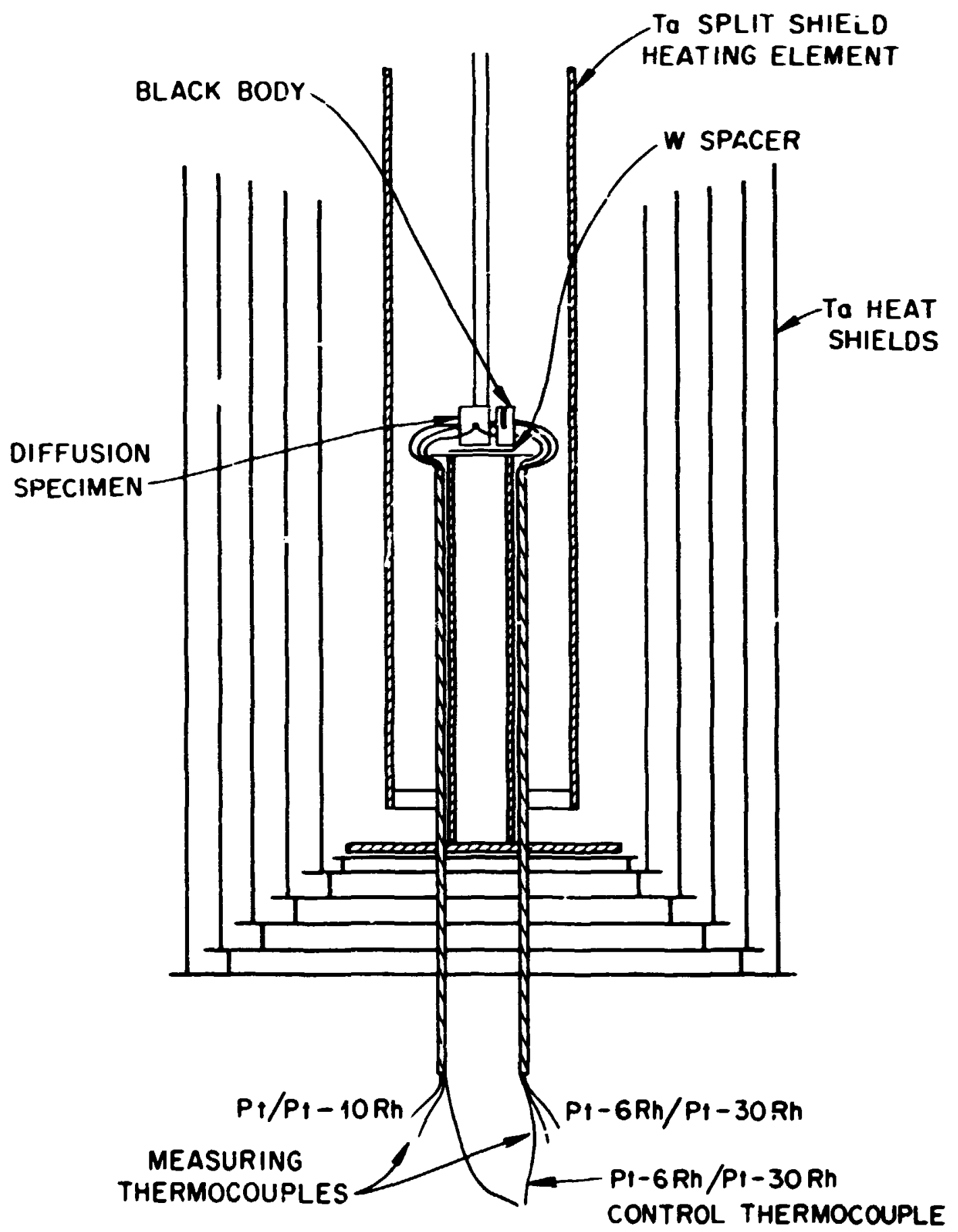

Fig. 10. Schematic draving of annealing furnace used in diffusion experiments. 
ot the zirconilm disk creates a black body used for temperature measurements with an optical pyrumeter.

The entire unit is located inside a metal beli jar capable of being evacuated to pressures of $10^{-6}$ to $10^{-5}$ torr. A port at the top of the bell jar is fitted with an optically flat quartz window and a rightangle prism to provide an optical path for the pyrometer.

Wiring Procedures and Control and Recording Systems

In all three apparetuses the thermocoupie wires are led-out of the system uninterrupted through ports sealed with silicone rubber or Teflon and from thence to an ice bath where they join low thermal emf copper telephone wires (see Appendix B).

\section{Anneeling Furnace}

1 schemstic of the wiring and of the recording and control instruments is show in Fig. 11. As may be seen, the copper wires from the control thermocouple go directly to an I\&N Series 60 CAT controller. The other two thermocouples run to a "thermal free" switshing station througn which they I:ay be connected to ar. L\&N Speedomax-H rocorder or a koneywell Rubicon Bodel 2750 potentiometer. The sutput of the recorder is used only to follow the heating and cooling transients at the beginning and end of an anneal. Only long period temperature oscillations with amplitudes of $\sim \pm 1^{\circ} \mathrm{C}\left(1.8^{\circ} \mathrm{F}\right)$ are observed about the control point durirg an anneal, and for reasons discussed below in connection with the oxidation rate apparatuses, these oscillations have a negligible effect on the diffusion rate.

\section{MiniZWOK}

The instrumentaticn for this apparatus is the most complex of the three and :s indicated schematicaliy in Fig. 6. Temperature control is intained witr a Research, Inc. Model D-30 MicroThe:mac Controller associated vith a Data-Trak Programer, Model FGE-5110. The latter unit is programmable for virtually any time-temperatir: regime. The 


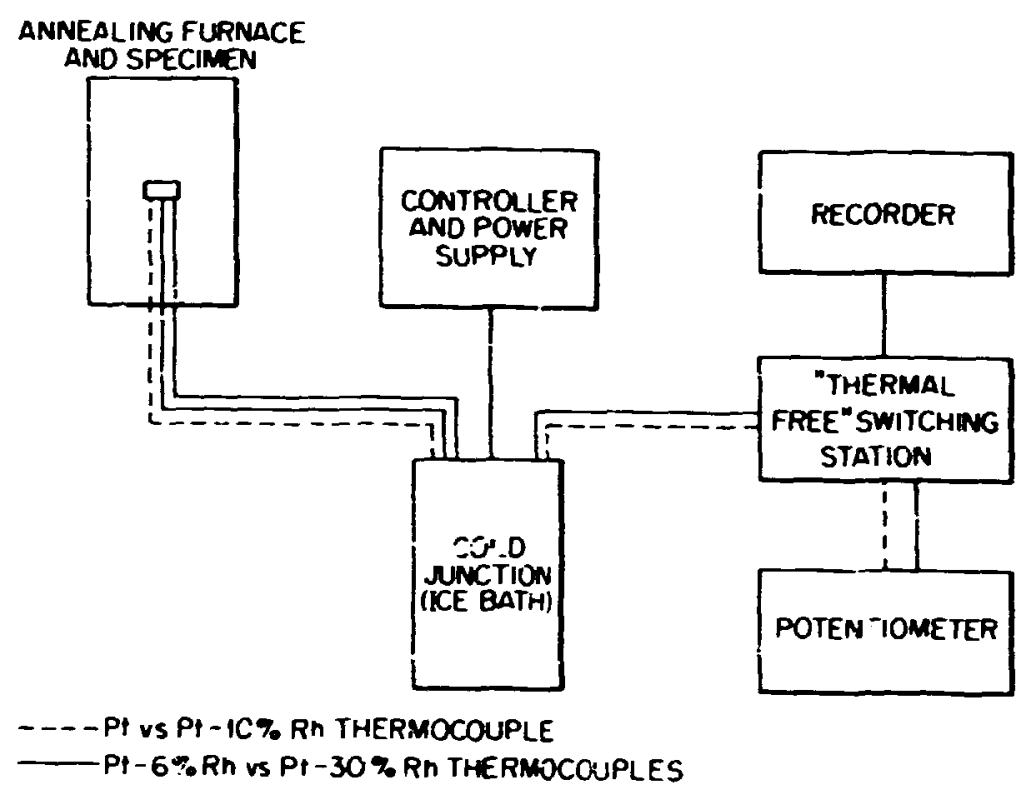

Fig. 11. Schematic diagram of instrument and wiring configuration for annealing furnace.

signals from the two measuring thermocouples after passing through a thermal free, multiposition switch (contact resistance $<0.001$ obm, thermal emf $<1 ; V$ ), may be 1 ) read on an L\&N K-3 potentiometer, 2) recorded by a two-channel strip chart recorder (Esterline Angus, Model 1102S, a mult1-spar unit with calibrated zezo), or 3) feed to computer operated data acquisition system (CODAS-III). The CODAS sysiem has been aescribed in detail elsewhere. ' In our system the CODAS-ITI computer perivdically reads the thermocouple emf ( 25 reading in $2 \mathrm{msec}$ ), calculates an average emf for the 25 readings, converts the emf to temperature according to the emf-temperature caibration for our particular Pt vs Pt-10\% Rh thermocouple wires, and prints the time and the averaged temperature at 2 sec intervals with the aid of a teletype. The CODAS-III system is calibrated directly before and after each experiment with a Dial-A-Source voltage unit (General Resistance, Inc., Model DAS-47Al) that itself is compared aga $\leq n s t$ our $K-3$ potentiometer. 
Care was exercised in properly wiring, grounding, and shielding the various components of the Min:TwOK control and recording system in order to eliminate ground loops and other parasitic emf's. In addition it was found that considerable tigh frequency noise was introduced into the system by the operation of the silicon controlled rectifiers of the fower supply for the quad-elliptical furnace. For this reason a low band pass filter with a cutofe above $50 \mathrm{~Hz}$ was installed between the multiposition switch and the CODAS amplifier (items 19 and 24 in Fig. 6). The filter, installed in each copper lead, consister of a series-connected, $50 \Omega$, manganin-wire wound resistor grounded through a $60 \mu \mathrm{m}$ milar capacitor.

The temperature control of which this system is capable ma be seen graphically in Fig. 7. Note the abrupt change from transient to isotherwal control. In the isothermal control regions only swall temperature fluctuations $\left.r \sim \pm 1.0^{\circ} \mathrm{C}\left( \pm 1.8^{\circ} \mathrm{F}\right)\right]$ about the control tempersture occur.

\section{MaxiTHOK}

Power to the steam superheater is cortrolled by the signal from the pt vs Pt-10\% Rh thermocouple loceted at. the uoper end of the reaction tube (see Fig. 8). An ice bath cold junction is atilized, and control is provided by an L\&N Speedomax $H$ recorder-controller. The furnace temperatire is controlled by the Chromel-Alumel thermocouple in the furnace annulus, again using a Speedomax $H$ controller with a built-in temperature compensator. The messuring Pt vs Pt-;O $\mathrm{Rh}$ thermocouples $a r \in$ fed into two Esterline Angus, Model 1102S reccrders; one of the couples is wired through an L\&N DPDT, low-thermal-emf, copper switch so that its signal can also be read on the $\mathrm{K}-3$ potentiometer. The calibration of the Esterline Angus recorders is checked before and after each experiment using a portable potentioweter; however, as in the case of MinizwOK, the accepted temperatures are based on the K-3 potentioneter readings. 
At the control temperature a temperature oscillations of about $\pm 2^{\circ} \mathrm{C}\left(3.6^{\circ} \mathrm{F}\right)$. Two frequencies and amplitudes of oscillations were observed related to the independent control of the steam superheater and furnace temperatures.

\section{Temperature Variations During Experiments}

Virtually any temperature control sjstem will procuce temperature oscillations about a control point, and the magnitude of this effect in our three apparatuses has just been described. We also investigated ${ }^{8}$ the effect of such oscillations on oxide and alpha layer growth in 7.ircaloy specimens in a series of computer simulated oxidation experiments. The types of teiperature cycles finvestigated are illustrated in Fig. 12. Comparison of such results with those calculated for strictly isothermal oxidation showed that neither F-penetration values (the sum of oxide and alohe layer thicknesses) nor total oxygen consumption is sensitive to such temperature cycles. For example, over a 90-sec period for

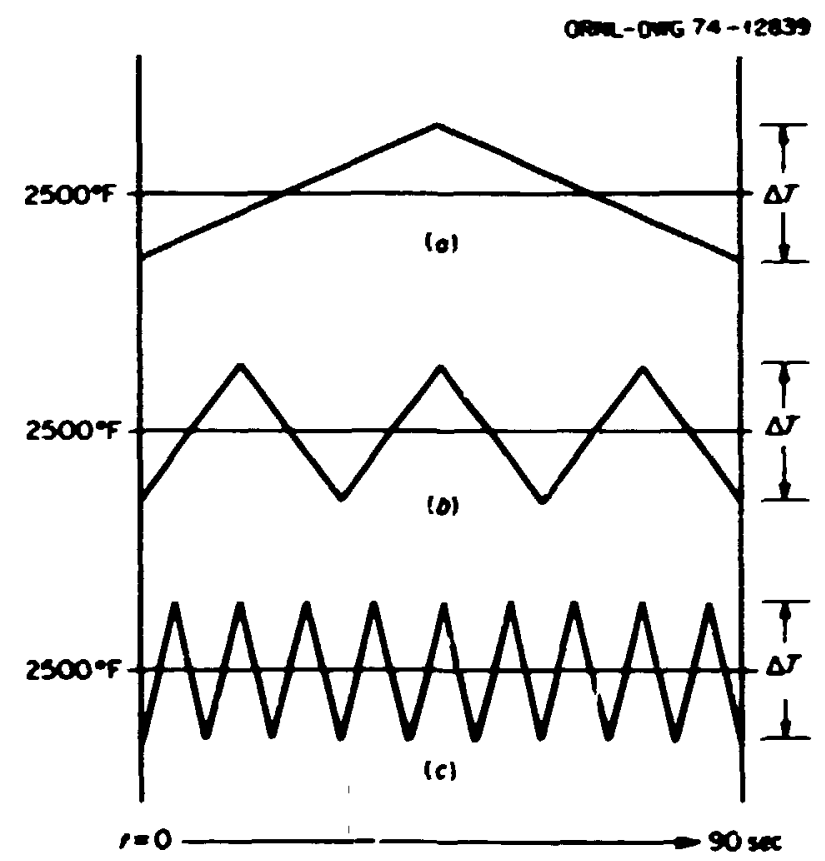

Pig 12. Cyclic temperature pattern used for computer similated oxidation experiments; $\Delta \mathrm{T}$ was varied up to $56^{\circ} \mathrm{C}\left( \pm 28^{\circ} \mathrm{C}\right.$ or $\left.\pm 50^{\circ} \mathrm{F}\right)$. 
oscillations with a frequency of $10 \mathrm{sec}^{-1}$ and an anplitude of $\pm 28^{\circ} \mathrm{C}$ $\left(50^{\circ} \mathrm{F}\right)$, differences of $l e s s$ than 0.54 in 5 and total agren were calculated.

Evidently, the average rate of oxidation is not changed appreciably by symetrical teperature cycling aboit a man. In light of the rect that axygen diffusion in a-zircaloy is the same kind of thermily activated process as oxidation, one wa also conclude that our dishasion results are insensitive to this type of control problen.

POTERIAL SOURES GP THERDCOUPLE ERRORS

Considerable care ast be exercised in the use of thernocouples at hizh tesperatures if serious teperature errors are to be avoided. This cautior is particularly relevant in system where experinentel requirenents create less than ideal conditions. We have considered the following list of potential errer sources in relation to the zeiok progran:

1. Thernal shunting

2. Electricel stunting

3. Parasitic ef's

4. Date acquisition syste errors

5. Thernocouple calibration errors

6. Terperature gradients in the sarple

7. Decalfbration of thernocouples

\&. Tab attachent effects.

In this section ve discuss the emor sources listed above as they apply t.o each of the three apparatuses used in the progran.

Thermal Sbunting

The t.ere "thersal shunting" is used here to sean the sbunting of heat to or frem the thernocouple hot junction by convection, conduction, or radiation. The process is illustrated in Fig. 13 for the case of thermal shunting by convection. Cool stean Ha.ing past the thermocouple 


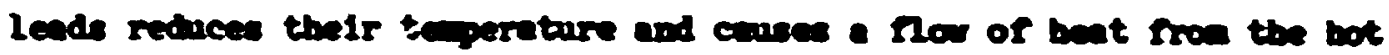

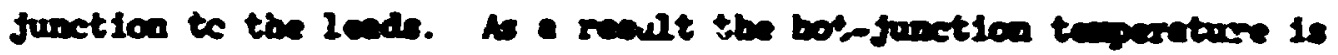

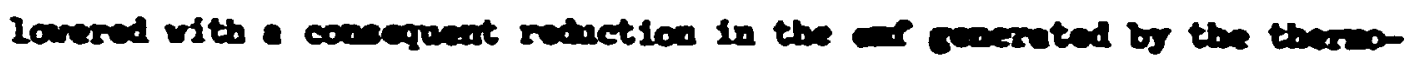

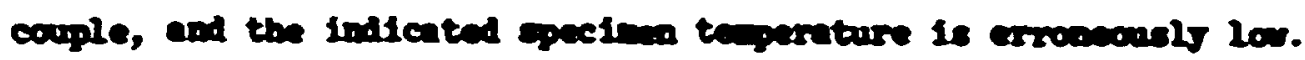

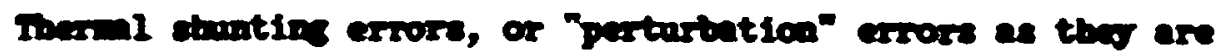

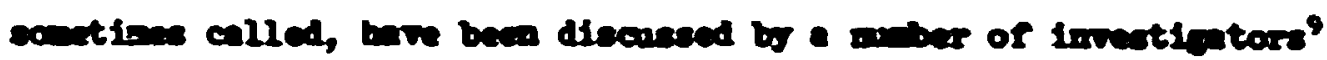

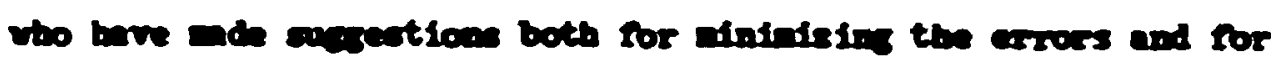
calcalatios their noitude.

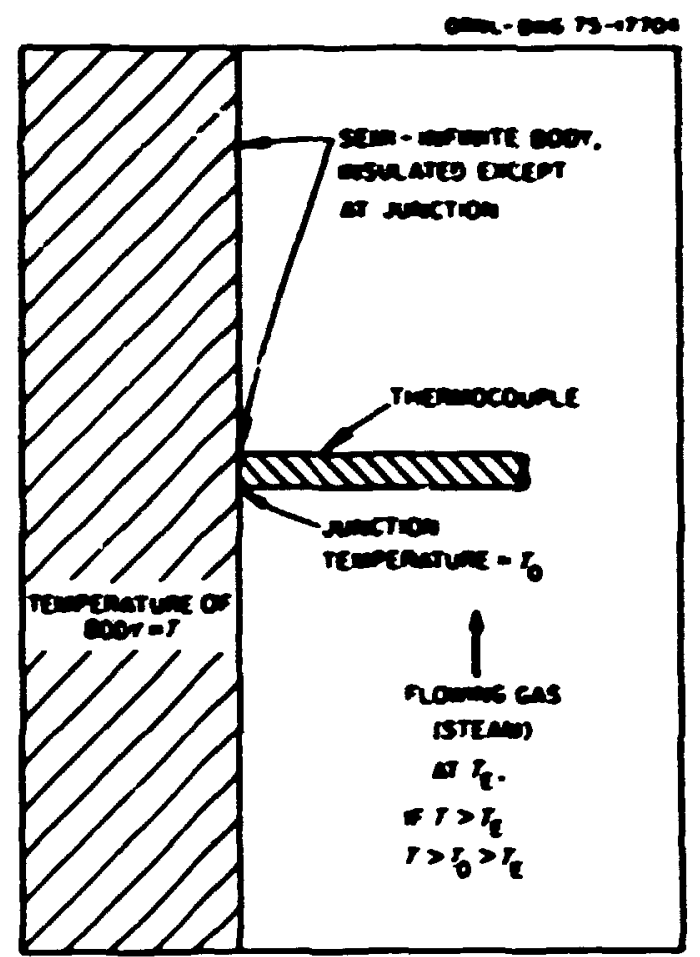

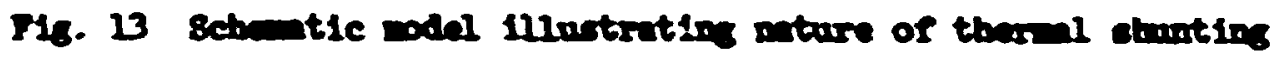
errore.

The anljtical proble is cacatially oos of extablishing on acceptable adel for the bat trangfer sution, and then colving the

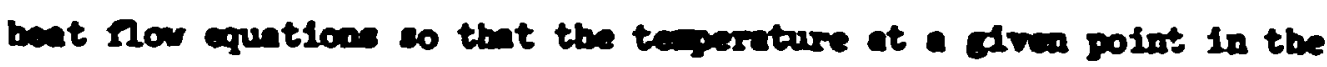
abeesce of the sensor can be calculated. Inile ach colution hare been obtalined ${ }^{10-12}$ for serervil case relewant to the operation of thermocouples on pecinens aupaded in horing ons strenn, these solutions are gener-

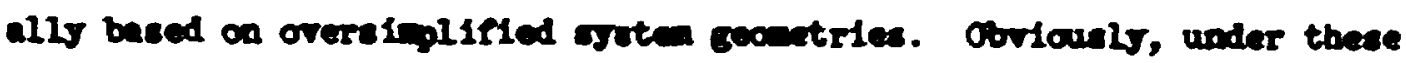


circunstances an experinental calibration of the system is desirable: but frequently it is iprectical or even impossible, as in our case, to carry out such a direct calibratior for a real system. For this reeson we bave taken the position that we should design our apparatuses in such a vay as to mininise perturtation errors, while at the same time nering use of existing computational procedures to estimate the agnitude of the errors involved and to guide the design work. Equations derived by nusselt (reported by Jakob ${ }^{15}$ and others) or Boelter ${ }^{11}$ proved userul in the iatter effort; and they have the addec virtue that, because of the mature of the assuptions made in each derivation, the calculated perturbation error is believed to be greater than the actual error. Thus the results depcribed belou may be regarded as indicating the approximate maxime possible perturbation error in our experiments.

The equation reported by Jakob ${ }^{10}$ is besed on the following model: in infinitely extended, howogeneous body bounded by a plane surface is perfectly insulated against heat loss except for a small circular area. From this area, a cylinder or wire extends perfendicular to the plane surface into an environment having a temperature different from tse unifor temerature of the body. The equation relates the temperature of the interface between the body and the wire to the temperatures of the body and its enviroment and to the several parameters that govern the flow of heat. The teperature perturbation created by a two-wire thermocouple is identical, at least for the ideal model, to that for a single wire. The heat flor from the junction il.: the wire is given by:

$$
q_{0}=\pi\left(2 \mathbf{k}_{w} \mathbf{h r}_{0}{ }^{3}\right)^{1 / 2}\left(t_{0}-t_{e^{\prime}},\right.
$$

where $k_{w}$ = therml conductivity if the thermocouple leads,

h = heat transfer coefficient between thermocouple leads and environent,

$r_{0}=$ radius of thermocouple leads

$t_{0}=$ temperature of the interface between body and environment (this is the temperature measured by the thermocouple), $t_{e}=$ enviroment (fluid) temperature.

A typographical omission exists in Jakob's ${ }^{10}$ presentation of this equation. 
The flor of heat out of the bods into the area created by the junction of the thernocouple lead is

$$
q_{0}=4 r_{i} \mathbf{r}\left(t-t_{\jmath}\right),
$$

where $r_{q}=$ the effective function radius, assuned to be identicel to the wire radius,

$k=$ thermal conductivity of the body,

$t$ = temperature of the body.

For steady-state conditions, the heat flows in Bqs. (2) and (3) are equal. ...s, combining the two expressions and rearrenging:

$$
t-t_{c}=\frac{\bar{k} \sqrt{\frac{k \sqrt{h r_{2}}}{g}}}{1+\frac{\pi}{k} \sqrt{\frac{k h r_{n}}{g}}}\left(t-t_{e}\right) .
$$

This expression affirms that the perturbation error $\left(t-t_{2}\right)$ in the temperature measurerent depends upon the temperature difference between the body and its environment $\left(t-t_{e}\right)$, the thenal conductivities of the body and the thermocouple leeds, and the heat transfer characteristics between the leads and the environent. Jakob also sugesests an espirical expression for the heat transfer coefficient $h$ which, wen substituted into the above equation, results in a perturbation error that is independent of the thermocouple wire dinmeter. However, Otter ${ }^{9}$ points out that in practice the wire size is generally a real variable.

Boelter et al. ${ }^{11}$ analjzed the perturbation error for the te-perature measurement of a thin plate with a cold fluid on ose side and a rot fluid on the other. The thermocouple is wounted with its leads perpendicular to the surface of the plaie in the hot fuid. Boelter's andel is not directly applicable to the specimen geometry and heat-ilow conditions in the MiniZwOK apparatus; however, within the limits set by the additional simplifying assumptions, the perturbation error should be similar for both cares. The analysis is based on a balance of heat transfer rates on the plate concentric about the thermocolple wire attachment area. The solution is given in several forms. Utilizing 
ecrerel aproulintion that are vilid for anll pertarbation errors, Boelter derived the folloring oquation:

$$
\frac{t-t_{c}}{t-t_{e}}=\frac{r_{0} \sqrt{2 h_{c}}}{k b}\left[-\ln \left(\sqrt{\frac{p}{2}} r_{z}\right)-0.57\right] \text {, }
$$

where $b=$ thicheas of the plate, $p=\left(h_{0}+h_{1}\right) / b k$, were $h_{-}$and $h_{1}$ are the pproprinte bent-transer coefriciests on the opposite sides of the plate, and the other subols wire the and neaning as in Bys. (2) and (3).

This equetion shors the relationship betareen the perturbation error $\left(t-t_{f}\right)$ ant the parmeters of the systen in a anoer geverells corsistent with by. (4). The then ocouple and plate dinensions eppear as more iportant veriables in Bq. (5). This obtains, at least in part, becuse of the different geometries and because of Boelter: assurption that no teperature gredient exists in the plate norml to its surfece. Pnr winiwe error, it is seen that the tbernocouple leads sbould have a lor thenal coaductivity and a anl dianeter; the plate should be thick and of high thenel cosluctivity. In addition, if the effective beat trinsfer coefficient, b, betreen the thernocouple and the flowing fuid can i.e decreased by insulation or by positioning, then the perturbation er.or will be reduced accordingly.

Bquation (4) was used to estimte the maxin perturbation error anticipated in our one-sided ifrizurok apparatus. A mjor uncertainty in the calculation lies in the assigment of the fluid (beliur or argon) tesperabure and flor characteristics in the vicirity of the trernocouple intallations. Not only does this temperature enter directly into the equation for the perturbation error, but the beat-transfer parneters are also inmlved. Por exaple, the effective beat transfer roefficient, $h$, between the fluid and the thernocouple wire can be calculated on the basis of forced convection at lor flor retes or on the basis of natural convection with assuned teperature differences in the systen. ${ }^{13}$ Both 
nethods Bive the same velue of b vithin a metor of 2 for lowsonductivity geses such as air. If ve ascume that a reacomble vilue for the beat transfer coefricient between tbe inert gas in Miniziox and

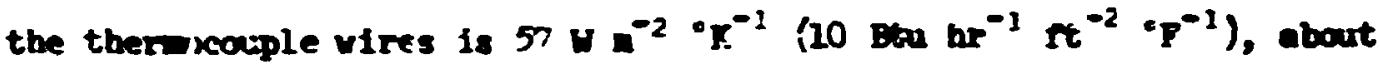
en order of mgnitude higher than the stear-apecimen bent tramfer coefricisat, then ve can calcuiate an aprouinte value for the pertarbetius error. The theriml conductivity of the thermocouple wire, $k$,

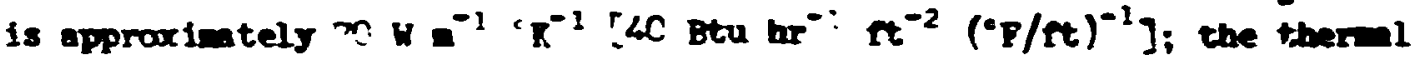

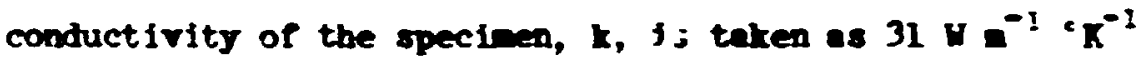

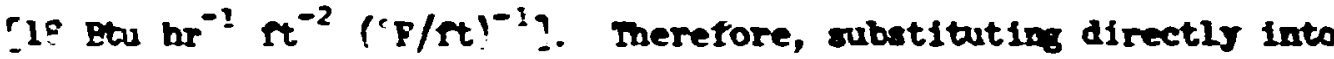
Eo. ( 4 ), ve obtain:

$$
?=\left(t-t_{i}\right) /\left(t-t_{e}\right)=0.025
$$

This reoult predicts that for bere-uire thermocouples extended at right angles into the inert gas strean the perturbation error will be 2.54 of the difference between the specinen and inert gas teperaturis. The effective argon or heliun ges tepereture in the viciatty of the thernocouple installation is inknow. However, asfie from circeintion ourng to canvection, the flor rate on the inside of the tube should be very sall, allowing the gas to be beated by contact vith the conponents of the systen tbat are beated directly by the radiant beating Nurnece. If, for exaple, the effective zas teperature in the cylindrical rolume defined by the specinen is within $100^{\circ} \mathrm{C}\left(180^{\circ} \mathrm{P}\right)$ of the specinen terpereture, then a wiman perturbation error of $2.5^{\circ} \mathrm{C}\left(4.5^{\circ} \mathrm{F}\right)$ would be anticipated. Of course, because our thermocouple installations are constructed to minimize this efiect, the actual perturbation error should be lei.. As described elsewhere in this report, the experinental reaults are consistent with the prediction that the perturbation error is anll for measurements of temperature in our one-sifed minizwox ouldation apparatus. As ephasized earlier, the Boelter equation, B. (5), for plate specimens was derived with a different wodel and sssuptions than those 
eployed for the case of the insulated sead-infinite slab. While ve have no besis for ascerteining which of these treetments is best suited to describe our particular system, it is of interest to note that the Boelter expression leads to a sinilar value for the perturtation error when the same aysten parametiers are used. Por our case, the "plate" thichness is $0.685-(0.00225 \mathrm{ft})$ : and we assure for purposes of calculation that the heat transfer coefricients on ejther side of the

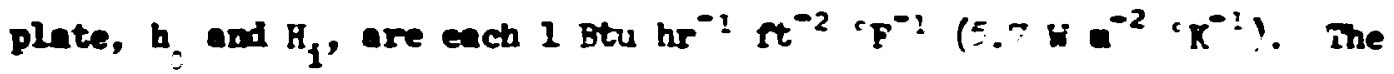
insertion of these values into Bq. (5) yields

$$
z=\left(t-t_{.}\right) /\left(t-t_{e}\right)=0.033 \%
$$

1turs. Eq. (5) predicts that the perturbation error will be $3.3+1$ of the difference between the specinen and coolant tenperatures, which is quite close to the error predicted by B. (L). In addition, the error is oaly coderetely dependent upon the particular values chosen for the plete heat transfer coefficient, 7 varying from about 4 to 24 as the coerficients change from 0.6 to $600 \mathrm{~N} \mathrm{~m}^{-2} \mathrm{~K}^{-}$" $(0.1-100 \mathrm{Btu}$ $\left.\mathrm{hr}^{-1} \mathrm{et} \mathrm{t}^{-2} \cdot \mathrm{p}^{-1}\right)$

The realts of these calculations are recngnized as being approxiate. Their contribution, therefore, lies not so mach in a precise prediction of error values but in the fact that they indicate the rel tlosship between some of the inportant system paraneters that effect tepereture neasurenent errors, thereby suggesting neans for reducing these errors to a uniam. Our thermocouple installations are constructed with these ideas in aind.

Therel shunting in the Minizwor sponratus

Our decision to construct the Minianor epparatus as a one-sided oxidation syoten with stean on the cutside and the thernocouples mounted internally vas a direct consequence of the need to aininize thermal shunting effects. Brors on the order of $100^{\circ} \mathrm{C}\left(180^{\circ} \mathrm{P}\right)$ have been observed in systen where the thernocxuples were exposed to rapidly nowing, cool stean. it A discussion of the mgnitude of such errors my also be found 
in Job.ob. ${ }^{1}$ In MinizwoK the thernocouples are subjected only to very slouly flowing beliur and the heliun itself is preneated as it passes over the hot $\mathrm{Ai}_{2} \mathrm{O}_{3}$ thermocouple inoulation in the lower portion of the apparatus. In normil experinents the beliun now rate through the center tube of the apparetus is $0.24 \mathrm{cc} / \mathrm{sec}$, and no changes in the measured enf's of the thernocouplea vere noted wen heliw flow rates were varled rrom 0 to $4.9 \mathrm{cc} / \mathrm{sec}$ (higher flon rates were not atte-pted) in the range of $\$ 00$ to $1300^{\circ} \mathrm{C}\left(1652-2372^{\circ} \mathrm{F}\right)$, Indicating the absence of any signiflant convective or conductive therml shunt,ing errors ouling to the flow of helfiu past the thernocouples.

In order to dininise the possibility of radiative thermel shunting, - tantalun beat shield is located in the upper portion of the 2ircaloy specinen (see Fig. 6). The $\mathrm{M}_{2} \mathrm{O}_{3}$ ther ocouple inoulation locuted in the brtton specinen support tube also acts as a heat, sbield. However, radiation losses from the thernocouple leads appeared to be sill in any case as ve observed no change in neasured specinen teperatures at - given furmce set point terperature with or without the tantalum neat shielis.

is already noted the thernocouples used in this apparatus are spot welded to tantalu tabs, and the tabs, in turn, are carefully spot welded to the interior of the specimen tubes. The thermocouple wires are led aray from the tab along the tube vall in a path parallel to the axis of the tube (supposedly the patin with the ninful thermal gradient) to minimize conduction errors (see inset, Fig. 6 ). The vertical sections of therwocouple wire between the tabs and the double-bore $\mathrm{Al}_{2} \mathrm{O}_{3}$ insulation (see inset, $\mathrm{Fig} .6$ ) are covered vith single-bort $\mathrm{Al}_{2} \mathrm{O}_{3}$ insulation. We have broken the single-bore insulation into swall pieses to minimize heat conduction to or away fron the hot junctions. However, comparison with unbroken insulation revealed no difference in the teperature neasurement. Therefore, unbroken single-bore insulation is eployed because it is easter to handle. 
These varicus design features and tests have led us to the conslusion that thermal sbunting errors in the Minigrok apparatus are negligible.

\section{Theral Stunting in the Maxizwor Apperatus}

Thermal shunting probless in this apperatus are relatively minor because in isothermal experinents both the stean and the furnace are at the sane terperature. Thus even though the therwocouples are exposed to rapidly floring stean, there can be no cooling effect. The possibility of thernl stunting does arise in experiments in which substantial specimen self-heating occurs and in which the furnace temperature is higher than the stean temperatures. We expect such errors to be ninimal, bowever, because 1) the difference between stean and specimen teperatures is relatively small - at, most in tine neighborbood of $200^{\circ} \mathrm{C}$ $\left(360^{\circ} \mathrm{F}\right)$, and 2) since the furnace temperature in mug cases is higher than the specimen iemperature, the errors dre to convective losses (stean effects) will be of opposite sign to those related to radiative effects (firnace wall temperature). In the worst case, using the perturbation error analysis aboye, we estimte errors due to tinermal shurting to be no more than $\sim 5^{\circ} \mathrm{C}\left(9^{\circ} \mathrm{F}\right)$.

Difrusion Annealing Apperatus

The constant temperature zone of the diffusion annealing furnace is relatively long $[7.3 \mathrm{ca}$ ( 3 in.) ] and the annesls are carried out in vacuum ( $\mathrm{A} \times 10^{-5}$ torr). The furnace is aiso well shielded (see Fig. 10). Thus factors leading to therwal stunting are, in general, not encountered in this systea. Their absence is borne out by the fact that for an anneal at, a nominal teperature of $1150^{\circ} \mathrm{C}\left(2102^{\circ} \mathrm{F}\right)$ readings of 1149.4 , 1149.6 , and $1150.1^{\circ} \mathrm{C}\left(2100.9,2101.3\right.$, and $\left.2102.2^{\circ} \mathrm{F}\right)$ were obtained with a Pt-ff Rh 88 Pt-30 Rh therwocouple, a pt vs Pt-10\% Rh therwocouple, and an automatic-belancing optical pyrometer, respectively.

\section{Mectrical Shunting}

Therwocouple errors my arise due to electrical leakage of the thermocouple insulators or to thermionic endssion between thermelements 
or other metals in the systen. These errors can be as large as several hundred degrees Celsius in certain environments and at very high temperatures [e.g., in argon at a pressure of 43 torr and at temperatures near $\left.1900^{\circ} \mathrm{C}\left(3272^{\circ} \mathrm{F}\right)\right]^{*}$ : However, in the current work this phenomenon was not a problen. For example, the resistance of an open circuit thermccouple at $1300^{\circ} \mathrm{C}\left(2372^{\circ} \mathrm{F}\right)$ in the MinizwoK apparatus was $5 \times 10^{5}$ ohms and $1.7 \times 10^{5}$ ohms at $1455^{\circ} \mathrm{C}\left(2.651^{\circ} \mathrm{F}\right)$, which are wch too high values to allow significant electrical shunting. in sinilar experiment in the vaxizwOK apparatus produced a value of $\sim 10^{4}$ ohms. The decrease in resistivity relative to that measured in MinizwoK was attributed to the fact that the lower ends of the raxizwOK tinernocouples are exposed to the distilled water of the quench bath for the apperatus; however, a resistance of $10^{6}$ ohns was still considered sufficiently higi to preciude the existerce of significant electrical sinuting. The best evidence for the absence of such effects in the diffusion furnace is the agreement between temperatures reasured by the thermocouples and the optical pyrometer; even at $1500^{\circ} \mathrm{C}\left(2732^{\circ} \mathrm{F}\right)$ these differences were within the calitration error iimits of the oyrometer.

\section{parasitic EPF's}

Temperature measurenent errurs can be calsed by the presence of Farmsitic enf's in the electrical sircuitry of thermocouples. Refererce here is made to slich effects as ground loops, roise, pickup, and probleas associated with the use of improper lead wires, reference junctions, feedthroughs, etc. The el inination of such error sources requires considerable care and the use of proper thermometry techniques. In settirg up the circuitry for all our systeas we worked closely with representatives of the Instruments and controls Division of $\mathrm{ORH}$, and the staps taken to overcome these problems have al ready been outlined in the section on Control and Recording of Teperature. 
Data Acquisition System Errors

Our primary standard used in measuring thermocouple enf's is a carefully calibrated Leeds and Northrup K-3 potentiometer or a Honeywell Rubicnn, Model 2780, potentiometer. The accuracy of the former is Biven as $0.015 \%$ of the measured emf plus $0.5 \mu \mathrm{V}$, while that of the latter is $I \mu \mathrm{V}$ or $0.015 \%$ of the measured emf, whichever is greater. Thus at $1500^{\circ} \mathrm{C}\left(2732^{\circ} \mathrm{F}\right)$ for a pt vs $\mathrm{Pt}-10 \% \mathrm{Rh}$ thermoccuple, each potentiometer has an accuracy of $0.2^{\circ} \mathrm{C}\left(0.36^{\circ} \mathrm{F}\right)$.

For our MinizwOK experiments time and temperature are also recorded yith a Computer Operated Data Acquisition System (CODAS;. This device is calibrated against the $K-j$ potenticmeter at the biginning of each experiment, and recalibrations immediately after an experiment revealed no change. Thus for short periods of time the accuracy of CODAS arpears to be comperasle to that of the $k-3$ itself.

\section{Thermoce xple Calibration Errors}

Thermocruple calibration procedures and uncertainty limit.s were described in detail in an earlier sectiou. This uncertainty is rreatest at temperatures above the gold point $\left[1064^{\circ} \mathrm{C}\left(1947^{\circ} \mathrm{F}\right)\right]$, and we estimete it to be $\pm 1.5^{\circ} \mathrm{C}\left(2 .{ }^{\circ} \mathrm{F}\right)$ at $1500^{\circ} \mathrm{C}\left(2732^{\circ} \mathrm{F}\right)$. Below the gold point the uncertainty is $\pm 0.8^{\circ} \mathrm{C}\left(1.4^{\circ} \mathrm{F}\right)$.

\section{Temperature Gradients in the Sample}

We have no evidence for the existence of temperature gradients within samples in the diffusion anneal furnace or in the critical part of the tubing used in the MaxizwOK apperatus. The MinizwoK samples, however, $\varepsilon r e$ not completely isotrermal. There is a longitudinal gradient of $4^{\circ} \mathrm{C} / \mathrm{cm}\left(7^{\circ} \mathrm{F} / \mathrm{cm}\right)$ from the center to the ends of the specimers. T.uere is also a circumferential variation (two-fold symmetry) in temperature of $\sim 7^{\circ} \mathrm{C}\left(13^{\circ} \mathrm{F}\right)$. The quad-elliptical furmace is built in two hinged sections that can be opened up to allow the insertion of the reaction tube. 
The hinge and corresponding opening on the other side of the furnace are located along the vertical center line of two opposed elliptic hemi-cylirdrical reflecting surfaces. The pasitions of the cooler regions on a specimer correspond to the positions of the hinge and opening, leading to the conclusion that these inperfections in the reflecting surfaces rechuce the efficiency of the furnace in these arsas.

These temperature gradients cause no particular problen for our measurements of oxide and alphe layer thicknesses since ve simply sectior the specimen at the thernocouple tabs and nake our metallographic measurements in the innediate vicinity of the tabs where the teperature is know. We did, however, investigate the possibility that, because of the seebeck effect, the existence of such thernal gradients could lend to the generation in the thermocouple of an additional enf that is proportional to the terperature difference between the two wires of the thermocouple at the hot junction.

A calculation was perforned for a thermocouple whose hot function consists of successive segments of $\mathrm{Pt}, \mathrm{Ta}$, and $\mathrm{Pt}-10 \% \mathrm{Rh}$. A tempereture gradient is assumed to exist across the function with $\mathrm{T}_{1}>\mathrm{T}_{2}, \mathrm{I}_{3}, \mathrm{~T}_{1}, \mathrm{~T}_{2}$ and $T_{3}$ being the temperatures at the $\mathrm{T} / \mathrm{T}$ junction, the midpoint of the $T$. segment, and the $\mathrm{T} / \mathrm{Pt}-10 \% \mathrm{Rh}$ junction, respectively. Let $\mathrm{E}_{M}$ and $\mathrm{E}_{\mathrm{T}}$ be, respectively, the emf's generated by the thermocouple and a similar thermocouple in which the Te segment is resoved. It can be shown that.

$$
E_{M}-E_{T} \approx\left(S_{T a}-S_{P t}\right)\left(T_{2}-T_{1}\right)+\left(S_{T a}-S_{P t / R h}\right)\left(T_{3}-T_{2}\right),
$$

where the $S_{x}$ 's are the appropriate absolute Seebeck coefficients. The results of this calculation are tabulated in Table 2 for the case $\mathrm{T}_{1}-\mathrm{T}_{3}=1^{\circ} \mathrm{C}\left(1.8^{\circ} \mathrm{F}\right)$.

The "Worst Case Error" listed in the table was calculated on the sssumption that the thermocouple leads are welcied at the edges of the tabs, thus producing a hot junction length of $2 \mathrm{~m}$. The vorst temperature gradient in our sample is $-0.8^{\circ} \mathrm{C} / \mathrm{mm}\left(1.4^{\circ} \mathrm{F} / \mathrm{mm}\right)$, thus creating a temperature gradient of $1.6^{\circ} \mathrm{C}\left(\mathrm{z} .9^{\circ} \mathrm{F}\right)$ across the not junction. 
In artarl practice ve attempt to keep the length of our thermocouple hot junctions at a minimu. Thus for a vell made thermocsuple jur.ction the error due to the Seebeck effect should be at least an order of magnitude smaller than those listed for the "Worst Case."

The calculations given above were made for a $\mathrm{Pt} / \mathrm{Ta} / \mathrm{Pt}-\mathrm{lOq} \mathrm{Rh}$ junction, wheres in actual practice the tantalum tab is attached to the Zircaloy tube. Thus the Zircaloy might also be expected to contribute to the Seebeck error. He bave wade a fer rough deterninations of the absolute Seebecik coefficient for Iirceloy 4 , however, and find it to be ipproximately $1 \mathrm{HV}$ greaier than that for tartaiun. Therefore, $\mathrm{r}_{\mathrm{i}}$. (8) may also be expected $t c$ give a reasonabie sstimate of the Seebeck effect temperature error for a $\mathrm{pt} / \mathrm{Ta}-\mathrm{Zr} / \mathrm{Pt}-\mathrm{l} 0 \% \mathrm{Rh}$ junction.

Table 2. Seebeck Effect Temperative Errors

\begin{tabular}{lccccr}
\hline $\begin{array}{l}\text { Temp } \\
\left({ }^{\circ} \mathrm{C}\right)\end{array}$ & $\begin{array}{c}E_{M}-E_{\mathrm{T}} /{ }^{\circ} \mathrm{C} \\
\left(\mu \mathrm{V} /{ }^{\circ} \mathrm{C}\right)\end{array}$ & \multicolumn{2}{c}{$\left(\mathrm{E}_{\mathrm{M}}-\mathrm{E}_{\mathrm{T}} / \mathrm{dE} / \mathrm{dT}\right) /{ }^{\circ} \mathrm{C}$} & \multicolumn{2}{c}{ Worst Case irror } \\
& $\left({ }^{\circ} \mathrm{C} /{ }^{\circ} \mathrm{C}\right)$ & $\left({ }^{\circ} /{ }^{\circ} \mathrm{C}\right)$ & -1.9 & -3.4 \\
\hline 900 & -13.70 & -1.2 & -2.2 & -2.2 & -4.0 \\
1100 & -18.60 & -1.4 & -2.5 & -3.0 & -5.5 \\
1300 & -22.70 & -1.9 & -3.4 & -3.5 & -6.3 \\
1500 & -26.2 & -2.2 & -4.0 & &
\end{tabular}

\section{Decalibration of Thermocouples}

This problem was discussed in the section on Thermocouple Calibration Procedures. As indicated, we have found no indication of decalibration during times much longer than the duration of our experiments.

Tab Attachment Effects

As already pointed ont, at temperatures above about $1100^{\circ} \mathrm{C}\left(2012^{\circ} \mathrm{F}\right)$ we find it necessary to insert small tantalum tabs between the Zircaloy and the thermocouples in order to circument the problem of the 
low-melting Pt-7r eutectic. The success of this arrangement oirisusly depends on establishing good thermal contact between the tabs and ibe specimen, and our normal procedure is to spot veld the tab to the specimen at several points. However, we have no way of determining prior to an experiment just how good the tab attachment might be, although in general it appears quite satisfactory. Note that "tab attachment effects" represent a special case of thermi shunting.

We have attenpted to establisi an upper bourd for tab attachment errors in the Minizwok apparatus by perferming an experiment in which one measuring thermocouple was attached to the specimen in the normal fashion while the second thermocouple was spot welded to a tab and the tab positioned in the approximate center of the specimen tube. Temperature differences of $9,11,10$, and $15^{\circ} \mathrm{C}\left(16,20,18\right.$, and $\left.27^{\circ} \mathrm{F}\right)$ were observed at $900,1100,1300$, and $1500^{\circ} \mathrm{C}(1652,2012,2372$, and $2732^{\circ} \mathrm{F}$ ), respectively. In this experiment the flow rate of helium through the interior of the specimen was varied from 0 to $\mathrm{f} \mathrm{cc} / \mathrm{sec}$ at each temperature; no change in the thermccouple readings was noted except at $900^{\circ} \mathrm{C}\left(1652^{\circ} \mathrm{F}\right)$ where a temperature drop of $1^{\circ} \mathrm{C}\left(1.8^{\circ} \mathrm{F}\right)$ was noted for the unattached thermocouple. These results set the maximam 2 imits for temperature errors due to poor tab attachment.

our regular experimental procedure requires an examination of both thermocouples and tabs after each experiment. Any indication of loose attachment, e.g., if the tab can be pulled loose with pair of tweezers, causes us to regard that experiment as suspect. Any accidental leakage of steam into the interfor of the specimen in quantities sufficient to produce significant oxidation of the thermocsuple tabs also leads to the rejection of the experiment. Thus, in a normal experinent, exrors due to posr tab attachment are expected to be mach smaller than the max:- given above and should approach zero for good attachments.

One indication $c r$ the existence of tab attachment errors may be cbiained by comparing the temperatures indicated by the two measuring thermocouples. Widely differing values suggest tab troubles. For example, if the tab to which the control and the first wasuring therwocouple are attached makes poor thermal contact with the specimen, 
the control thermocouple will sense a teperature lower than that of the specinen. The teserature of the specimen vill thus increese until the enf roquired by the controller is generated by the control thernocouple. The first weasuring thermocouple (attached to the sane thib as tice control thernocouple) will indicate approximately the expect:ad temperature; however, the second measuring thernocouple (assured to be well attached! will indicate a relatively high teperature - in this case the true temerature of the specimen.

The requirenent that reasonable agreement exist between the two neasuring thermocouple teperatures is not an absolute neasure of tab attachnent quality. Real temperature differences may exist in the specimen, spurious teperature differences may arise because of the Seebeck effect (see above), or the two tabs may both be poorly attached. With regard to the latter problen, the probability that the thermal attachment of both tabs will be equally poor seems small, but, clearly, the only real cure for tab attachent effects is to make sure that good bonding is achieved between tab and specimen, and we make every effort to see that that is done.

The above discussion applies primarily to the MinizwOK apparatus. We consider tab attachment effects to be considerably less serious in MorizwOK and the anneeling furnace because in these two apparatuses tabs, when usea at all, are attached to the outside of the specimens, and problems of welding and weld inspection are substantially simplified.

EVALUATION OF TEMPERATURE ERRORS

In this section we consider the magnitudes of the total temperature measirement exrors in our experimentel systems.

Determinant Errors

Certain parts of the temperature measuring system used with given apparatus may be calibrated against externai standards, and a quantitative estimate of the error associated with each component can be obtained; 
suct errors are usually referred to as the deterdinnt errors of the system. The deterinant teperature errors for our three qparatuses are sumarized in Tables 3 and 4.

\section{I=jetensinint Brors}

It is corsiderably more difficult to specify quantitatively the indeterninant teperature neasurenent errors associnted with our experinental systens. Indetendinat errors are those related to procedures or apparatus features not susceptible to direct, independent calfbretion as are, for ecuifle, thernocouples. Braples of such errors include the problem of tinenal and electrical shunting, decalibration of therrocouples, tab attachnent effects, and spurfous ex's associnted ws sh tesperature gradients across the therwocouple bot junctions (the Seebeck effect).

MinizaroK

On the basis of evidence sited in the section on nror Sources we feel that errors related to thenal and electrical shunting and thernocourple decalibration are essentially negligible. Tab and Seebeck ef:ect errors depend on the care exercised in installing the thernocouples. At worst they can amount to 15 to $20^{\circ} \mathrm{C}\left(27-36^{\circ} \mathrm{F}\right)$, but in general such gross errors are easily detected tbrough post-test netallography and a direct examination of the tabs. In acceptahle experiments, for reasons given in previous sections, suck errors are expected to te much less than maximum, although we cannot give a quantitative estimate of their magnitudes.

$\underline{\text { MaxizTOK }}$

Again for reasons already given, we believe that electrical shunting and thernocouple decalibrations errors are negligible in this epparatus. Errors due to thermal stunting are also very small for lsothermal experiments, although we estimate that such errors may reach $5^{\circ} \mathrm{C}\left(9^{\circ} \mathrm{F}\right)$ in our "mixed temperature" experiments where the furnace temperature 
exceeds the stean teperature. The relative ease with which thermocouples ay be installed and the absence of significant thermal gradients in this apparatus tend to winimize both the tab and Seebeck effects.

\section{enneal ing Furnece}

The lang isotherml zone of the furnace precludes the existence of Seebeck Effect errors in this apparatus, and tab installation procedures appear bighly satisfactory (note the extensive bonding achieved between tab and specimen shown in Fig. 3, page 9). The other errors discussed above are likerise smill.

\section{Total Error Estimtes}

The total teperature error for a given apparatus is the sum of the deterninant and indeterninant errors for the system. The determinant errors for the MinizwOK and mazwoK apperatuses are listed above and ve bave already cited evidence for our belief that the indeterminant errors are smell. It is inossible tc quantify them; however, in other studies ${ }^{15}$ it has been observed that the probable absolute accuracy error of terperature neasurenents in a vell designed system is two-to-three tines the reproductibilty. Thus, taking the determinant error as an estimate of reproducibility, we give as the probable temperature measuresent error in MinizwOK and for isotinemal experiments in MxizwOK values ranging from $\pm 4^{\circ} \mathrm{C}\left(7.2^{\circ} \mathrm{F}\right)$ at $900^{\circ} \mathrm{C}\left(1652^{\circ} \mathrm{F}\right)$ to $\pm 6^{\circ} \mathrm{C}\left(10.8^{\circ} \mathrm{F}\right)$ at $1500^{\circ} \mathrm{C}$ $\left(2732^{\circ} \mathrm{F}\right)$. In the worst case we belleve that we can specify temperature acsurately to $\pm 10^{\circ} \mathrm{C}\left(18^{\circ} \mathrm{F}\right)$. During transient temperature tests in the MaxizWOK apparetus where the temperatures of the steam, the furnace, and the specinen are all diffezent, the temperature error will be silghtly larger than that, given arjve, the additional uncertainty reaching an est insted $\pm 5^{\circ} \mathrm{C}\left(9^{\circ} \mathrm{F}\right)$ for those situations where, because of specimen selfheating, the specimen temperature is significantly above that of either the steasn or the furnace. 
Table 3. Determinant Temperature brrors in che MinizwOK and MaxizwOK Arparatuses

\begin{tabular}{|c|c|c|c|c|c|c|}
\hline Error Source & & & Touperature & Error, deg., & at & \\
\hline & $900^{\circ} \mathrm{C}$ & $1\left(5^{5} 2^{\circ}\right)^{\circ}$ & $1380^{\circ} \mathrm{C}$ & $\left.2\} 8^{\circ}\right)^{\circ}$ & $\left.{ }^{1500} \mathrm{C}\right) \mathrm{C}$ & 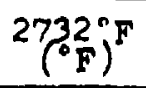 \\
\hline Uncertainty relative to IPTS -68 & \pm 0.3 & \pm 0.5 & \pm 0.7 & +1.3 & +1.0 & +1.8 \\
\hline Thermocouple terial varlebllity & 0.5 & 0.9 & 0.5 & 0.9 & 0.5 & 0.9 \\
\hline Potent lometer & 0.16 & 0.28 & 0.19 & 0.34 & 0.24 & 0.43 \\
\hline Potent lomoter rear: out & 0.33 & 0.59 & 0.33 & 0.59 & 0.33 & 0.50 \\
\hline Thermas. & $\infty .01$ & $\infty .02$ & $\$ .01$ & $\infty .02$ & $\infty .01$ & $\infty .02$ \\
\hline Reference (1 ze bath) temperature & 0.01 & 0.02 & 0.01 & 0.02 & 0.01 & 0.02 \\
\hline Total & \pm 1.3 & +2.3 & +2.7 & +3.2 & +2.1 & +3.7 \\
\hline
\end{tabular}




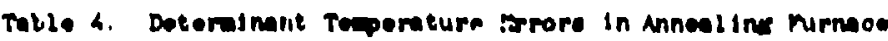

\begin{tabular}{|c|c|c|c|c|c|c|c|c|c|c|}
\hline Error souro. & & & Tempen & ture hrr & des, ot & & & & & \\
\hline & $m 00$ & 20.9 .7 & $146 " 1$ & l's"r & $\ln (x)^{\circ} 6$ & .110 .7 & $\operatorname{lin} m \cdot 1$ & 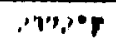 & $1 \times n+c$ & $m+r$ \\
\hline \multicolumn{11}{|l|}{$\begin{array}{l}\text { Pliernocouples } \\
\text { incetele inty rulative to InTy-ne }\end{array}$} \\
\hline pe valu-la! Rh & 0,1 & .0 .9 & & & !1. ' & 11.1 & & & 11.1 & $1, *$ \\
\hline 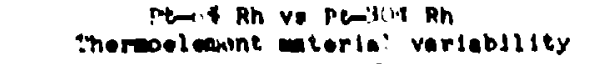 & $\because 3$ & $\begin{array}{l}0,13 \\
0,11\end{array}$ & & & $\begin{array}{l}3.11 \\
? .9\end{array}$ & $\begin{array}{l}\text { l." } \\
\text { n," }\end{array}$ & & & $l_{n}^{1 .:}$ & $\because \%$ \\
\hline 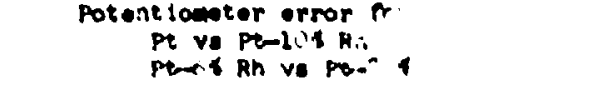 & 0.12 & 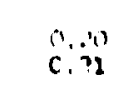 & & & 0.16 & $n, . "{ }^{\prime \prime}$ & & & $n$ ind & $\begin{array}{l}0.3 \% \\
0.24\end{array}$ \\
\hline Potent liveter roadine arro. & 0.20 & 0.11 & & & $n,:^{\prime \prime}$ & 0.14 & & & $0,20,1$ & $1.1 *$ \\
\hline Therml -.r in ipper laade & .8 .01 & Q. 0.1 & & & 6,12 & $-11,13$ & & & 9.11 & $a_{1}, n_{i}$ \\
\hline reforenee (1ce bath) tme errol. & 0.02 & $0.1 \%$ & & & 9,18 & 11,11 & & & $\therefore 1$ & $\therefore n$ \\
\hline 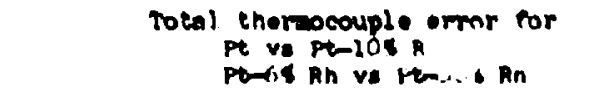 & 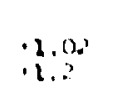 & $\because 2 .+1$ & & & 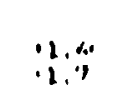 & $\because \because$ & & & 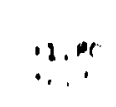 & $\because \cdots$ \\
\hline \multicolumn{11}{|l|}{ 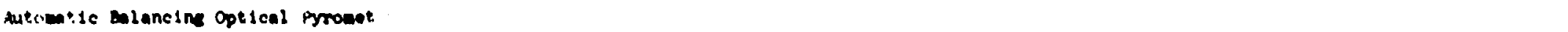 } \\
\hline mo calibration orror for strip . . plo & & & 1,9 & $\therefore$ & & & & & $\cdots 1$ & $1, \cdot$ \\
\hline Doviation of pyrosoter table & & & $19, n$ & $\because \cdots$ & & & & & 11,11 & 11 \\
\hline "A" velue error for virilon prias & & & 11.1 .1 & $1,7 \cdot$ & & & & & 19,34 & $r \cdot 1$ \\
\hline $\begin{array}{l}\text { Error in determintine ref sroncie letep } \\
\text { current }\end{array}$ & & & $0 . \because$ & 11.126 & & & & & $\therefore$ & $\because$ \\
\hline Total & & & $11 . "$ & 11 & & & & & $\because \therefore$ & $\cdots$ \\
\hline \multicolumn{11}{|l|}{ Vunually Bolanced Pyrower } \\
\hline Eror in calibrutine otrip i $p$ & & & 1.9 & $\therefore \cdot$ & & & $1 *$ &.$\cdot$ & & \\
\hline "A value error for vindow prian & & & "1" & $1.7 \%$ & & & 0.14 & $\because \cdot$ & & \\
\hline Inetrument roe ll1ty orror & & & $\because n$ & 1.8 & & & $\therefore 0$ & ?. & & \\
\hline rotal & & & $\therefore$. & $\because \cdot$ & & & $\cdot 1.1$ & ". . & & \\
\hline
\end{tabular}


Idditional evidence for the velidity of our tepereture error andysis is arilable fren an eranation of coide lajer thichesses on the axidized Iircaloy saples. Because of the thenal gradients in our saples or an ecoount of seall mirietions of the control point betureen experineats, ve observe nesurable disferences in arial thichess at different points around the circurerence of a saple, difterences that can be correlated vith differences in teperatare as indicated by

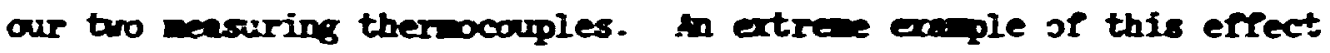
occurred if an experiment wtere the norinal axidntion teperature wes $13 \mathrm{C}^{\circ} \mathrm{C}\left(23 \mathrm{~T}^{\circ} \mathrm{F}\right)$. The neasuring couple read $1307^{\circ} \mathrm{C}\left(2385^{\circ} \mathrm{P}\right)$ and the other 132; C (2424"F); the cors spoi if aride thichesses neasurel at the positions of the two capies vere 53 and 7 is, respectively. Becmuse - : prelininary -esilts appear io agree vell with the provious data of Hobson, i6 we can "-s the activation 6 jeternined tron Fobson's data to aiculateri wia tiöchesue spesth at 1307 and $1329^{\circ} \mathrm{C}\left(2385-2424^{\circ} \mathrm{F}\right)$.

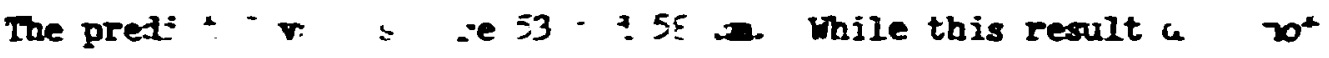
bear 1: o absciute sccura, of our', grature wer 'tis, 't does indicate that the ro-"- errors are saili and well "thi:. 'be ncertainty 1 inits piven.

The o; real to qua. - the - aterwinant errors in ex. ontal apparatus is to mare esults obtained wth those neasur : a a completelv sifferent apparatus or by a completely ifferent wetboc We vill be abi: - mire " comparions on - we mplete the data acquisition. - of tine progr $\cdot n$, . expect - comar further ial this regard . the final report $c .$. i:. project.

The total aperature error fr the annealing furnace used in the aiffusion exf iments is somewhat $c$.ivier to assess in that tewperature seasur sents were made using both therwocouplez an an optical pyronc ir. Thus we-have tro i: Jependent checks on temers $\cdots .$. z compare these results in PIg. 14 where $t l \quad " \quad$ ing of the Pt . Pt-10\% Rh thermocouple is treated as the reference temperature, and the differences betreen that temperature and those indicated by the Pt $-6 \% \mathrm{Rh}$ vs Pt-30\% Rh thermocouple and the pyrometer are plotted as a function of the reference temperature. 


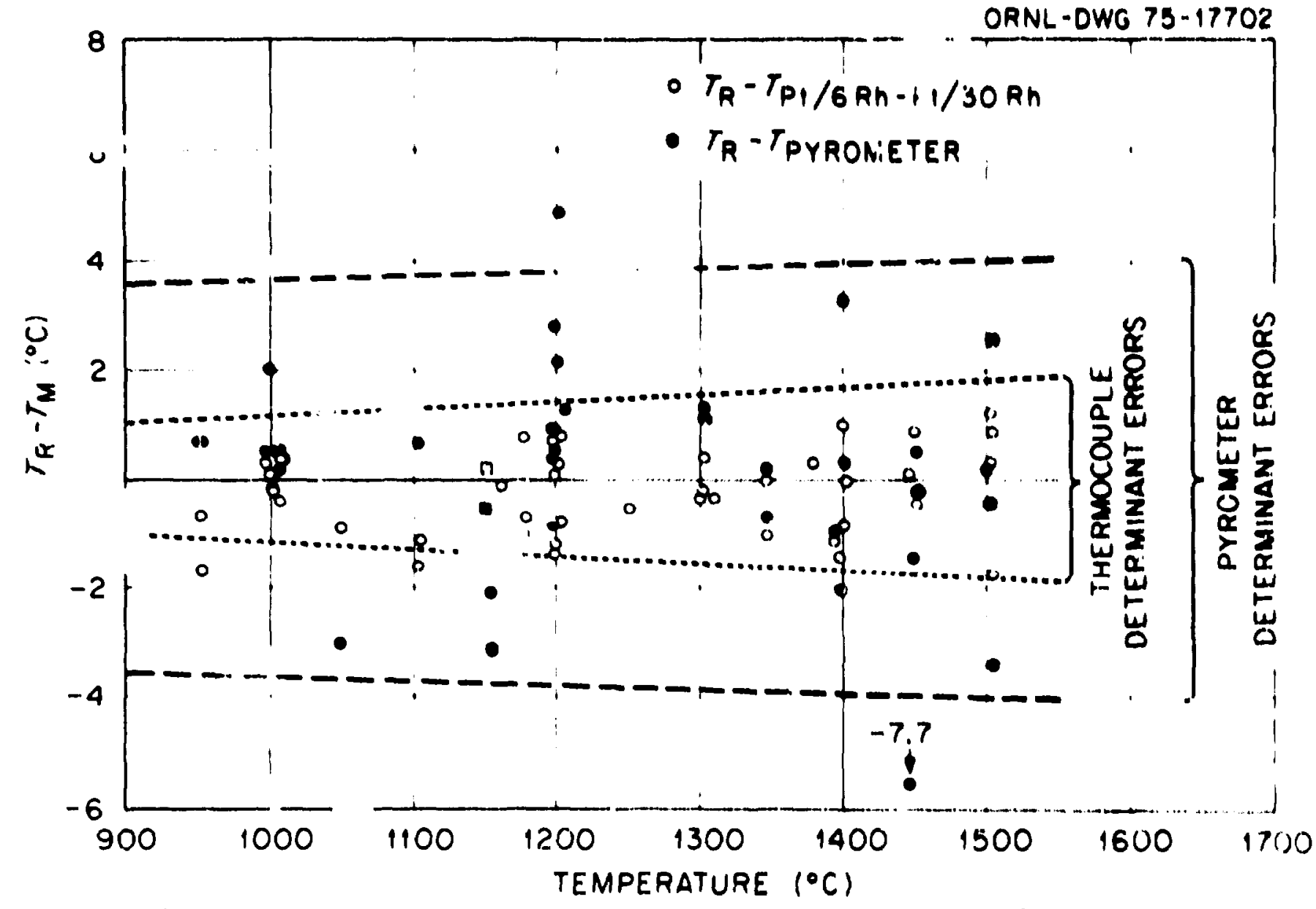

F1g. 14. Plot of temperature differences among therwououples and pyrometer as a runction of reference temperature. Temperutures, $\mathrm{T}_{\mathrm{P}}$ indlcated by the $\mathrm{Pt}$ va $\mathrm{Pt}-1,0 \mathrm{Rh}$ therwocouple "ere taken as reference temperaturea alld compared w1 th $T_{W}$ the temporatures of the pt-t. va Pt-30\% Rh therrocouple (open circlee) and of the plroweter (olosed clrcles). 1 .... open end closed squares at $1250^{\circ} \mathrm{C}\left(2102^{\circ} \mathrm{I}\right)$ refer to manouremente made with the Pt-6\% Rh va Pt-30\% Rh thermocouple and the automente balancine pyrometer, roupeotively. 
As $a y$ be seen, wre tion of of the differesces mall within the deterninnt exror band for the thernocuples and saly two prioneter readings lie outside the corresponding error bund for the psrometer. We conclude, therefore, that the ebsolnte error for our tempreture neasurenents in the amealing furmee is not greater than the deternimnt

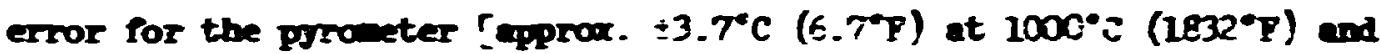

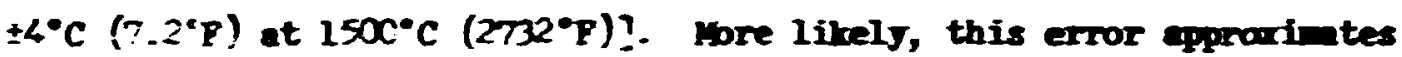
the deterwinnt error for the thernocouples $I_{ \pm} 1^{\circ} \mathrm{C}\left(1.8^{\circ} \mathrm{P}\right)$ at $00^{\circ} \mathrm{C}$ $\left(1652^{\circ} \mathrm{F}\right.$ ) and $\pm 2^{\circ} \mathrm{C}\left(3.6^{\circ} \mathrm{P}\right)$ at $\left.1500^{\circ} \mathrm{C}\left(2738^{\circ} \mathrm{F}\right)\right]$.

\section{Influence of Teperature Errors on Oxidation Rate Constant Deternimtions}

As indicated in the Introtuction, the oxidation rate constant is on exponential functioc of recifmon teperature, and relatively sall errors in teperatire neasurenent can lead to large errors in the determination of the rate corstant. The error relationships shown in Fig. I vere calculated on the assurption that the rate constant was deterniried on the basis of one temperature measurement. In actuality our determinations of rate constants are based on ten different oxidation experiments of five different time durations, two experinents being carried out at each time. Tru- the extent that ou- tesperature measurement errors are rai . . . ocedure tends to average out the effect of temperature errers.

In order to test the magnitude of this averaging we performed a series of computer simulation experiments in which the oxida": n temperature was assumed tr vary randomly in the interval $\mathrm{T}-10^{\circ} \mathrm{C}<.+10^{\circ} \mathrm{C}$, where $T$ is the nc al temperature of the experiment. The temperotures were distributed as a normal random variable with mean, $T$, with a $95 \$$ probability that they lay within the desired temperature interval. These temperature values were then fed into the standard oxidation rate equation

$$
\xi^{2}=\mathbf{k t}
$$




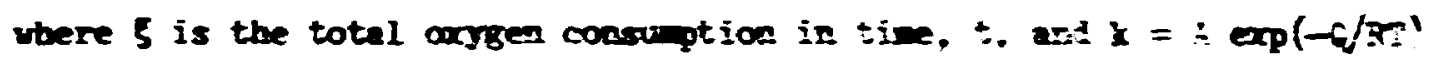

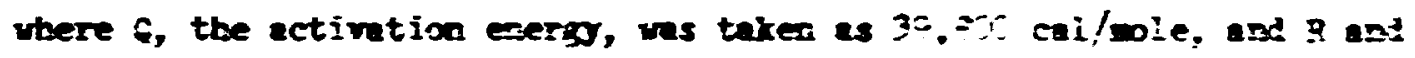
I ere the gns corstant and the trie tenperatire respectiveiy. The relies of the $t$ 's selected vere those ectulis ised in our experimests. In orier

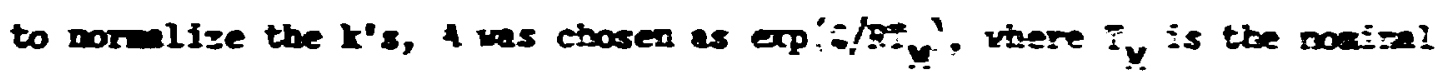
te-peratare of the experiment; thus for the case viere tice tempereture error is zero, the slope of alot of $\xi^{2}$ rersis $t$ is inity.

on inis basis a thousand axilation rate cirre: vere generated for cach tenpersture considered and a least siceres iic of ticeir slopes obtained. The arsiage and the stardard deriation for each set of ore thousend estinted slopes is sumarized in inble 5.

Table 5. Average and Standard Deviation of 100 Similated slopes True value of the slope is $K ! T^{\prime}=1$

\begin{tabular}{|c|c|c|}
\hline $\begin{array}{c}\text { Te-pernture } \\
\text { ('c) }\end{array}$ & $\begin{array}{l}\text { Average } \\
\text { Slope }\end{array}$ & $\begin{array}{l}\text { Slope } \\
\text { Stendard } \\
\text { Teviation }\end{array}$ \\
\hline 300 & 1. $-x, 3 x$ & 2.05669 \\
\hline 1000 & 1.00045 & 2.25550 \\
\hline 1100 & $1.000 \leq 3$ & 0.04593 \\
\hline 1200 & 1.00014 & 3.03476 \\
\hline 1300 & 1.00030 & 0.03123 \\
\hline 1400 & 1.00025 & 0.02535 \\
\hline 1500 & 1.00012 & 0.02221 \\
\hline
\end{tabular}

A more meaning ful display of these same data was obtained when the range of values of the estimated slopes was divided into intervals and the frequency of occurrence of the values in each interval plotted in histogram form. The histogram for the $1300^{\circ} \mathrm{C}\left(2372^{\circ} \mathrm{F}\right)$ is shom in Fig. 15. As might be expected for a normally distributed variable, it was found that at all temperatures at least $95 \%$ of the estimated 


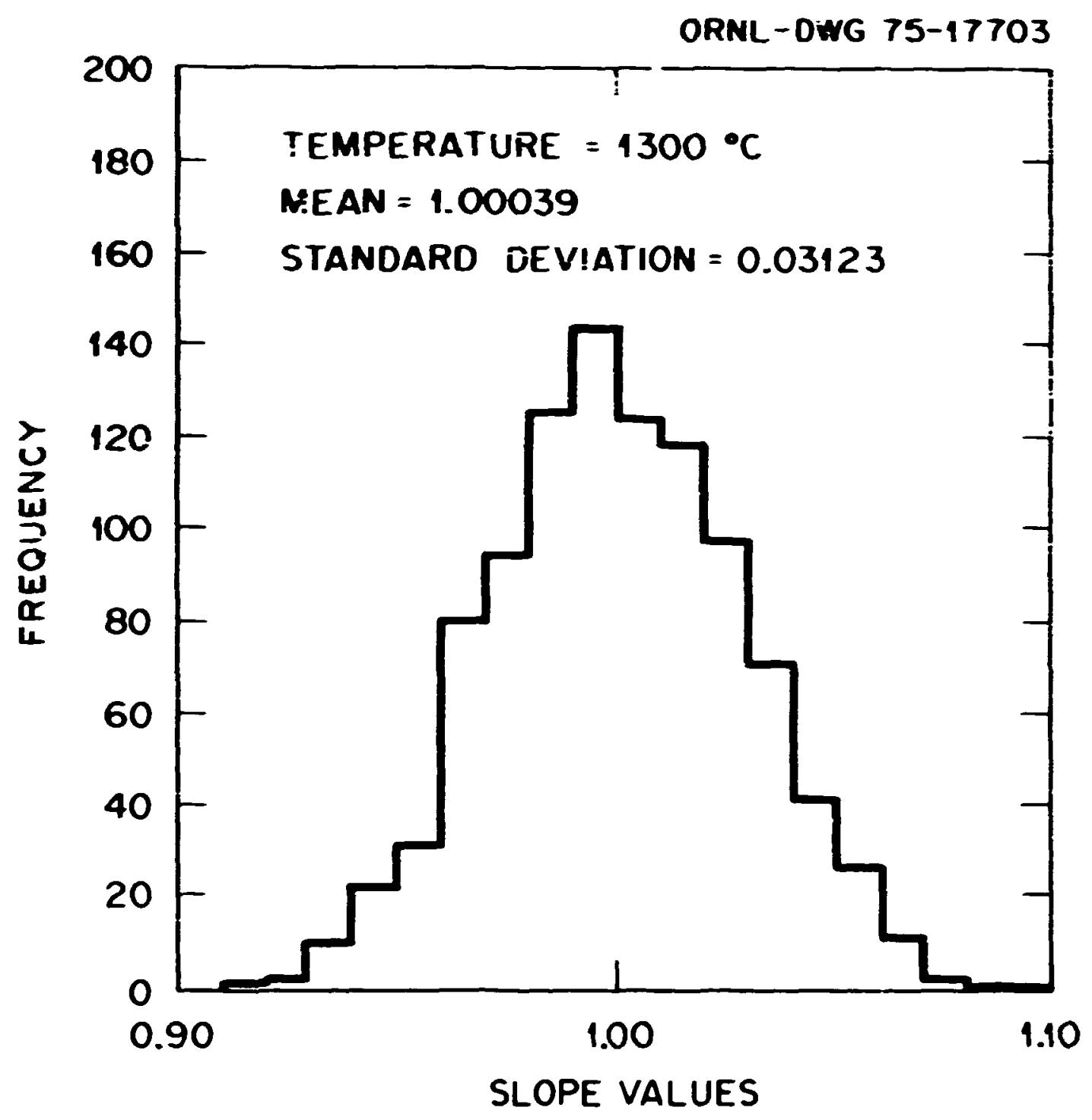

Fig. 15. Histogram of estimated slopes of oxidation rate curves calculated for $1300^{\circ} \mathrm{C}\left(2372^{\circ} \mathrm{F}\right)$. 
slopes have values in the interval $1 \pm 2 \sigma$, where $\sigma$ is the standard deviation. The intervals containing 90,95 , and $99 \%$ of the data are shown in tabular form in Table 6.

Table 6. Irtervals : Wich Contain Approximately 90\%, 95\%, and 99\% of Simulated Slope Values

\begin{tabular}{cccc}
\hline Teuperature & $\begin{array}{c}90 \% \\
\text { Interval }\end{array}$ & $\begin{array}{c}95 q \\
\text { Interval }\end{array}$ & $\begin{array}{c}99 \% \\
\text { Interval }\end{array}$ \\
\hline 900 & $0.92-1.08$ & $0.90-1.10$ & $0.86-1.14$ \\
$1000^{\circ} \mathrm{C}$ & $0.92-1.10$ & $0.90-1.10$ & $0.88-1.12$ \\
$1100^{\circ} \mathrm{C}$ & $0.94-1.08$ & $0.92-1.08$ & $0.90-1.10$ \\
$193^{\circ} \mathrm{C}$ & $0.95-1.05$ & $0.94-1.07$ & $0.92-1.08$ \\
$1300^{\circ} \mathrm{C}$ & $0.96-1.05$ & $0.95-1.06$ & $0.93-1.07$ \\
$1400^{\circ} \mathrm{C}$ & $0.97-1.05$ & $0.96-1.05$ & $0.94-1.06$ \\
$1500^{\circ} \mathrm{C}$ & $0.96-1.03$ & $0.95-1.04$ & $0.94-1.05$
\end{tabular}

Consider the first entry in the $90 \%$ interval at $900^{\circ} \mathrm{C}$ in the table. This result means that, given our experimental procedure and assuming a rantom temperature error of $\pm 10^{\circ} \mathrm{C}\left( \pm 1.8^{\circ} \mathrm{F}\right)$, there is a $90 \%$ probability that we will determine the rate constant to $\pm 8 \%$ at $900^{\circ} \mathrm{C}\left(2652^{\circ} \mathrm{F}\right)$. The error predicted from Fig. 1 is $\pm 15 \%$. As might be expected. the anticipated error decreases with increasing temperature. Thus at $1500^{\circ} \mathrm{C}\left(2732^{\circ} \mathrm{F}\right)$ the predicted ersor range for the $90 \%$ confidence level is $\sim 3 \%$.

This statistical treatment is presented not as a prediction of expected future results but ratiner as an indication of the extent to which the effects of random temperature errors cen be 1 inimized. It is unfortunately true that, indeterminant temperature errors, especially, tend to be systesatic rather than random, and it is obviously essential that every effort be made to insure the greatest possible accuracy in temperature measurements. 


\section{CONCLUSIONS}

Accurate measurement of temperature in the experimental piase of the Zirconium Metal-Water Oxidation Frogram is essential. Through careful apparatus design and the use of well calibrated Pt vs Pt-10\% Rh and Pt-6\% Rh vs Pt-30\% Rh thermocouples we have been able to achieve the following estimated uncertainties for the probable accuracy of temperature measurements in ihe three experimental apparatuses used.

1. MinizwOK oxidation apparatus: $\pm 4^{\circ} \mathrm{C}\left(7.2^{\circ} \mathrm{F}\right)$ et $900^{\circ} \mathrm{C}\left(1652^{\circ} \mathrm{F}\right)$ and $\pm 6^{\circ} \mathrm{C}\left(10.8^{\circ} \mathrm{F}\right)$ at $1500^{\circ} \mathrm{C}\left(2732^{\circ} \mathrm{F}\right)$.

2. MaxizwOK oxidetion apparatus: same as above for isothermal experiments; for nonisothermal experiments there is an additional uncertainty estimated tc reach $\pm 5^{\circ} \mathrm{C}\left(9^{\circ} \mathrm{F}\right)$ in extreme situations.

3. Annealing Furnace: $\pm 1^{\circ} \mathrm{C}\left(1.8^{\circ} \mathrm{F}\right)$ at $900^{\circ} \mathrm{C}\left(1652^{\circ} \mathrm{F}\right)$ and $\pm 2^{\circ} \mathrm{C}$ $\left(3.6^{\circ} \mathrm{F}\right)$ at $15 \mathrm{CO}^{\circ} \mathrm{C}\left(2732^{\circ} \mathrm{F}\right)$.

The maximum possible error appears to be $\sim \pm 10^{\circ} \mathrm{C}\left(18^{\circ} \mathrm{F}\right)$ for isothermal oxidation experiments and no more than $\pm 4^{\circ} \mathrm{C}\left(7.2^{\circ} \mathrm{F}\right)$ for the annealing furnace. 


\section{REFERENCES}

1. Quarterly Progress Report on Reactor Safety Program Sponsored by the Division of Reactor Safety Research for April-June 1974. I. Light Water Reactor Safety, ORN L-TM-4655, Vol. I, August 19?!:.

2. "The International Practical Temperature Scales of 1968" (adopted by the Comité International des Poids et Mesures), Metrologia $\underline{=}(2)$, $35-44$ (1969).

3 W. T. Gray anả D. I. Finch, "Accuracy of Temperature Measurements," Temperature, Its heasurement and control in Science and Industry, $\underline{4}(2), 1381-13 \%$, ed. by Harmon $\mathrm{H}$. Plumb, Societ y of America, 1972.

4. D. T. Hawkins and R. Hultgren, "Constitution of Binary Alloys," in Metals Handbook, Vol. 8, American Society for Metals, Metals Park, Ĵto, 1973, p. 33 .

5. M. Hansen, Constitution of Binary Alloys, McGraw Hili, New York, 1958, p. 1226.

6. R. K. Williams, "A Study of the Electrical Resistivity of Zone-Refined Tungsten at High Temperatures," J. Appl. Phys. 46, 475-490 (1975).

7. T. G. Kollie, D. L. Mcélroy, R. K. Adams, and̃ J. M. Jansen, "Measurement Accuracy of a Computer-Operat ed-Data-Acquisition System," in Temperature, Its Measurement and control in Science and Industry, Vol. 4, Part, 2, H. H. Plumb, ed., Instrument Society of America, Pitisburg, Pa., 1972, pp. 1457-i466.

8. Quarterly Progress Report on Reactor Safety Progran Sponsored by the Division of Reactor Safety Research for October-December 1974. I. Light Water Reactor Safety, ORNL-TM-4805, Vol. I, April, 1975.

9. Summaries of pertinent phenomena, approaches, and remedies are given in (a) A. T. Otter, Thermocouples and Surface Temperature Measurement, AECL-3062 (March 1968) or (b) thnual on the Use of Thermoccaples in Temperature Measurement, American Society for Testing and Materials, Spec. Tech. Publ. 470A, Philadelphia, 1974, particulariy Chapter 9.

10. M. Jakob, Heat Transfer, Vol. II., Hiley, N. Y., 1957, p. $14 \%$.

11. L. M. K. Boelter et al., An Investigation of Alrcraft Heaters, XXVIII - Equations for Steady-State Temperature Distribution Caused by Thermal Sources ia Flat plates Applied to Calculation cf Thermocouple Errors, Heat-Meter Corrections, and Heat Transfer by PIn-FIn Plates, NACA-TN-1452 (1948). 
i2. L.M.K. Boelter and R. W. Lockhart, Thermocouple Conduction Error Observed in Measuring Surface Temperatures, NACA-TN-2427 (1951).

13. W. H. McAdams, Heat Transmission, kicGraw-Hill, New York, 1942, pp. 219 and 237.

14. R. R. Biederman, A Study of Zircaloy-Stean Oxidation Reaction Kinetics, First Interim Progress Report, January-Mhrch 1975. Project No. 249-1 Electric Porer Research Institute, Palo Alto, California.

15. D. L. McElroy and J. P. Moore, "Radial Hea; Flow Methods for the Measurement of the Thermal Conductivity of Solids" in Therma? Conductivity, Vol. I., R. P. Tye, ed., Academic Press, New York, 1969, p. 190.

16. D. O. Hohson, "Ductile-Brittle Behavior of zircaloy Puel Cladding," in ANS Topical Meeiing on Water Reactor Safety, Salt Lake City, March 26-38, 1973. Published by TIC (COAF-730304). 


\section{ACKNONLED MENTS}

Many people have coniributed to the work duscrived in this report. The authors are particularly grateful for the efforts of R. L. Anderson, T. G. Kollie, and J. L. Horton, all members of the Metrology Research and Development Laboratory of the Instruments and control.s Division at ORNL. J. J. Campbell, R. E. Druschel, R. S. Craves, F. J. Weaver, and R. A. Padgett contributed much to the experimentel work of the program, and E. T. Rose was responsible for the metallography required. S.H. Jury, Professor or Chemical Engineering at the University of Tennessee and a consultant on our program, made many helpful suggestions rezarding our temperature measurement problens, and without the help of

T. G. Godfrey the use of the CODAS to collect data would have been impossible. C. K. Bayne of the Computer Sciences Division performed the statistical analysis used in estimating the effect of temperature errors on rate constant determinations. Finally we express our appreciation to Mrs. Carol Carter for her patience and expertise in typing and assembling the report. 


\section{APPENTIX A}

Calibration of Pt vs Pt-10\% Rh (Type S) and Pt-6\% Ph vs Pt-30\% Rh Thermosouples from 25 to $1500^{\circ} \mathrm{C}\left(77-2732^{\circ} \mathrm{F}\right)$

Five thermocouples were fabricated fram Sigmund Cohn wire as indicatea in Table 1 . The wires were welded in an oxygen-acteylene flame, cleaned with acetone and alcohol and then annealeci by electrical selfheating according tc the following schedule: $1-2$ min at $1400^{\circ} \mathrm{C}\left(2552^{\circ} \mathrm{P}\right)$, $15^{-30}$ min at $1200^{\circ} \mathrm{C}\left(2192^{\circ} \mathrm{F}\right), \mathrm{hr}$ at $1000^{\circ} \mathrm{C}\left(1832^{\circ} \mathrm{F}\right)$, and $2 \mathrm{hr}$ at $500^{\circ} \mathrm{C}$ $\left(932^{\circ} \mathrm{F}\right)$.

The annealed thermocouples were threaded into high purity, DeGussit AL-23 alumina insulators. For Run 1 thermocouples designated ZWOK-SI, S2, S3, and B1 were welded to the bead of the laboratory standard SL-7913. Run \#2 included SL-7913, SL-7912, and ZWOK-SL as indicated in Table 2. The assembly was inserted into a high purity, DeGussit AL-23 proteztion tube, open to the air, and this tube mounted in a furaace. The thermoelements were bruight, directly to reference junctions mafintained at O̊র bj arushed ice in a Dewar flask. Untinned copper leads (Western Eiectric telephnne cable) were used to connect the thermoelements to the selector switch at the potentiometer. The selector switch was a silver alloy Leeds \& Northrup switch. The switch was wired so that not only could the output of the individual thermocouples be read, but also the emf between the standard platimm thermoelement and the test platinum thermcelements as well as the emf betwen the test alloy therwoelemenis and the standard alloy thermolement could be read. The emf's of the thermocouples were read using a Gufldline 9930 DCC potentiometer. The jata were recorded on paper tape for later computer processing.

The furnace was a tube-type furnace with a Pt-alloy teating element and was controlled oy a Type $S$ thermocouple attached to a CArtype controlier. The furnace porer was supplied by an SCR-phase-eired power supply. 
Table 1. Test Thermocouple Characteristics

\begin{tabular}{|c|c|c|c|}
\hline Pesignation & Type & Wire Dia. & wterial Identification \\
\hline TIOF-31 & $\mathbf{s}$ & $\begin{array}{l}3.020 \text { in. } \\
0.020 \text { in. }\end{array}$ & $\begin{array}{l}\text { Pt, Bar } 452 \text {, and a } \\
\text { pt-10\& Rh, Bar } 345 \text {, End a }\end{array}$ \\
\hline TSOK-S2 & $\mathbf{s}$ & $\begin{array}{l}0.020 \text { in. } \\
0.020 \text { in. }\end{array}$ & $\begin{array}{l}\text { Pt, Bar } 452 \text {, Fnd } b \\
\text { Pt-10f Fi, bar } 345 \text {, and b }\end{array}$ \\
\hline TWOK-S & $s$ & $\begin{array}{l}0.010 \text { in. } \\
0.010 \text { in. }\end{array}$ & $\begin{array}{l}\text { Pt, Bar } 452 \text {, End } a \\
\text { Pt-1Oq Rt, Ber } 345 \text {, End a }\end{array}$ \\
\hline MUK-SH & $s$ & $\begin{array}{l}0.010 \text { in. } \\
0.010 \text { in. }\end{array}$ & $\begin{array}{l}\text { Dt, Bar 452, End } \mathrm{b} \\
\text { pt-104 Rh, Ber 345, End } \mathrm{b}\end{array}$ \\
\hline TWOK-BI & $\mathrm{B}$ & $\begin{array}{l}0.010 \text { in. } \\
0.010 \text { in. }\end{array}$ & $\begin{array}{l}\text { Pt- } 4 \text { Rh, Lot No. } 914 \\
\text { Pt-309 Rh, Lot No. } 013\end{array}$ \\
\hline
\end{tabular}

Table 2. Calibration Information

\begin{tabular}{|c|c|c|c|c|c|}
\hline \multirow{4}{*}{$\begin{array}{l}\text { Run } 1 \\
\text { Run } 2\end{array}$} & \multicolumn{2}{|c|}{ Test Therrocouples } & \multirow{2}{*}{$\begin{array}{c}\text { Standard } \\
\text { Thermocouples }\end{array}$} & \multirow{2}{*}{${ }^{\circ} \mathrm{C}}$. & \multirow{2}{*}{$\stackrel{\text { Temp. }}{{ }^{\circ} \mathrm{F}}$} \\
\hline & 0.020 in. diam & $0.01 C$ in diam & & & \\
\hline & S1, & 53, $\quad \mathrm{Bl}$ & SI 7913 & 1500 & 2732 \\
\hline & & 54 & SL 7913, SL 7912 & 1500 & 2732 \\
\hline Run 3 & st & New, old & SL 7913 , SL 7912 & 1000 & 2732 \\
\hline
\end{tabular}


On the first run, the contrul ibernocuple wa locet in the wll of the rurnace. Above about $100^{\circ} \mathrm{C}$ (1632\%), electrica: icabage caised the measurements to be increasingly instable, and at $1300^{\circ} \mathrm{C}$ (2372" $\mathrm{F}$ ) the leakage increased to the point that reliable readings coild not be made nor the furnace controlled. The rumace us cooied to roon temperature, and ar. electricel shield for the alyina protection tube was mie by winding a platirum wire on the aluaina tube and cannecting it outside the furrac: to ground. At the same tive the contral therwocouple was transferred into the aluaina protection tube. Tais seened to solve the problems caused by electrical leakage. jasles 3 and 4 shou the thernocouple and thermolement comparisons iar ZNUK 31 before the electrical leakage was corrected and for $\mathrm{ZWCK} 54$ after the correction. The latter case shows afreement to better than $1.0 \mathrm{uV}$.

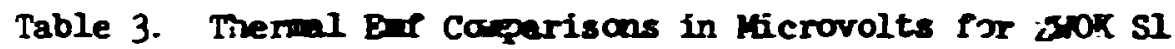
Thermocouple and Thermolements to Reference SL 7913 Before Electrical Ieabage Correction

\begin{tabular}{|c|c|c|c|c|c|}
\hline \multicolumn{2}{|c|}{$\begin{array}{l}\text { Nominal } \\
\text { Tesperature }\end{array}$} & $\begin{array}{l}\Delta \mathrm{Pt} \\
\text { Std.-Test }\end{array}$ & \multicolumn{2}{|c|}{$\begin{array}{l}\text { Thernoelements } \\
\Delta \text { Alloy }\end{array}$} & $\begin{array}{c}\text { Therwocouple } \\
\triangle \text { ER } \\
\text { Std.-Test }\end{array}$ \\
\hline 25 & 77 & 0.1 & 0.6 & -j.5 & 0.4 \\
\hline 200 & 39 & 1. & 0.5 & 1.3 & 1.2 \\
\hline 400 & 752 & 1.9 & 0.2 & 1.7 & 2.3 \\
\hline 600 & 1112 & 1.2 & 2.6 & 3.8 & 3.9 \\
\hline 700 & 1292 & 1.3 & 2.9 & 4.1 & 4.3 \\
\hline $80 n$ & 1472 & 1.4 & -3.3 & 4.7 & 4.8 \\
\hline 900 & 1652 & 1.7 & -3.6 & 5.3 & 5.4 \\
\hline 1000 & 1832 & 2.0 & -3.7 & 5.7 & 6.1 \\
\hline 1100 & 2012 & 4.1 & 2.3 & 6.4 & 7.6 \\
\hline 1300 & $2 j 72$ & -28.0 & 41.5 & 13.5 & 9.5 \\
\hline $1400^{8}$ & $25 \% 2$ & 1.9 & -9.1 & 10.0 & 10.6 \\
\hline $1500^{8}$ & 2732 & 0.8 & -8.5 & 9.3 & 10.2 \\
\hline
\end{tabular}

Measurements mace after shielding installed. 
Teble 4. Thermal enf comarison in Microvolts for Zwok 54 ithernoccuple and Inermcelements to Reference SI 7933 After slectrical Leakage Correction

\begin{tabular}{|c|c|c|c|c|c|}
\hline \multicolumn{2}{|c|}{$\begin{array}{l}\text { roninal } \\
\text { zepere ture }\end{array}$} & $\begin{array}{c}\Delta \text { Pt } \\
\text { std. - Test }\end{array}$ & \multicolumn{2}{|c|}{ Therwolewents } & $\begin{array}{c}\text { Thermocouple } \\
\text { A EF } \\
\text { Std.-Test }\end{array}$ \\
\hline 25 & 77 & 0.1 & & & $-C .2$ \\
\hline 20 & 392 & -0.3 & $\propto .4$ & C.l & 0 \\
\hline 400 & 752 & $-c .7$ & -1.1 & 0.3 & 0.3 \\
\hline 600 & 2112 & -0.4 & -0.9 & 0.5 & 0.5 \\
\hline 700 & 1292 & -0.5 & $-1 . ?$ & 0.8 & 0.6 \\
\hline 800 & $147 \mathrm{E}$ & -0.8 & -1.5 & 0.7 & 0.9 \\
\hline 900 & 1652 & -0.6 & 2.0 & 1.4 & 1.3 \\
\hline 1000 & 1832 & -0.3 & -1.3 & 1.0 & 2.0 \\
\hline 1100 & 2012 & -0.2 & 2.7 & 2.5 & 2.2 \\
\hline 1200 & 2132 & $-C .2$ & -3.1 & 2.9 & 2.7 \\
\hline 1300 & 2372 & 0.2 & -3.4 & 3.6 & 3.4 \\
\hline 1400 & 2552 & 1.0 & -3.3 & 4.3 & 4.9 \\
\hline 1500 & 2732 & 2.2 & -3.4 & 5.6 & 4.7 \\
\hline
\end{tabular}

Standards

The prifary standard used in all rums was ORerl Type $S$ standsrd Si-7913. In the second run, a nate to this thermocouple, SI-7912, was included, to check that SI-7913 had not been changed by the high temperature treatient in the firat calibration run. The outputs of the two stancard thernocouples agreed within 1 wV over the entire range of temperatures.

SL-7913 and SL-7912 are two thermocouples nade from specially prepared wire acquired from S1gund cohn and given special calibrations 
at the NBS; they were two of our six primary thermocouple temperature stancards until the new Type S "exact" alloy was defined by NBS Monograph 125. Tbe voltage measurements were referenced directly through the Guililine potentiometer to one of the satureted standard cells used to maintain the value of the volt at ORIL.

\section{Results}

Tables and flots were calculated for each thermocouple using the ORIL thermocouple cailibration program. These were referenced through ST-7913 and the Nonograph $125^{*}$ functions to IPIS-68. Figure 1 is a piot of the deviation of ZWOK-SI, ZWOK-S3, and ZWOK-S4 from the exact Type $S$ thi rmocouple as a function of temperature. The average values for three thermocouples, ZWOK-AVE, was used to prepare a single table representing the 2WOK thermocouples. As Fig. I shows that the spread of these themocouples amounts to about $\pm 0.5^{\circ} \mathrm{C}$. The line in Iig. 1 is least squares fit of the data to a third-degree polynomial. The behavior of ZWOK-S1 only is shom in Fig. 2. Thermocouple ZWOK-S2 was not included in the calculations of 2WOK-AVE because of 80mewhat wore scatter in the data as shown in Fig. 3. This scatter is probably due to the electrical leakage observed at the 1100,1200 , and $1300^{\circ} \mathrm{C}(2012$, 2192 , and $2372^{\circ} \mathrm{F}$ ) points, since the points at $1400^{\circ} \mathrm{C}$ and $1500^{\circ} \mathrm{C}(2552-$ $2732^{\circ}$ ) taken after installation of the shield wire agreed vith the other two thermosouples in Run 1 run within about $\pm 0.1^{\circ} \mathrm{C}\left(.18^{\circ} \mathrm{F}\right)$. It is not clear wh ZWOK-S2 was affected by the leakage wore than other thernocouples.

\footnotetext{
"Robert L. Powell, Willian J. Hall, Clyde H. Holnt, Jr., Larry L. Sparts George H. Burns, Margaret G. Scroger, and Firon H. Plumb, "Therocouple Reference Tables Based on IPIS-68," IBS ronograph 125 (Mreh 1974).
} 


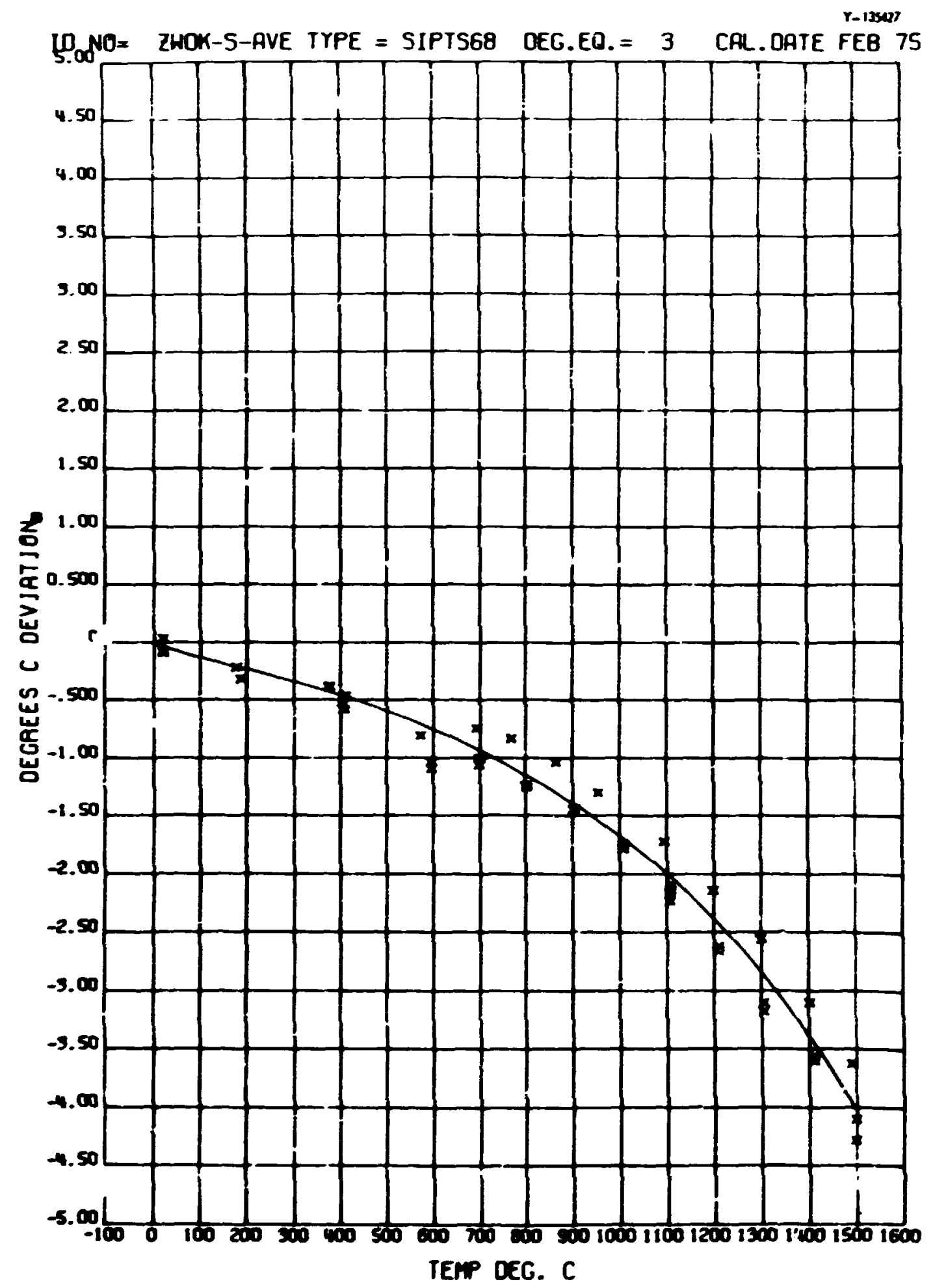

F1g. 1. Therwocouple deviation data fur ZwOK S1, ZwOK S3, and ZWOK S4 from exact Type $S$ thermocouple as a function of temperature. 


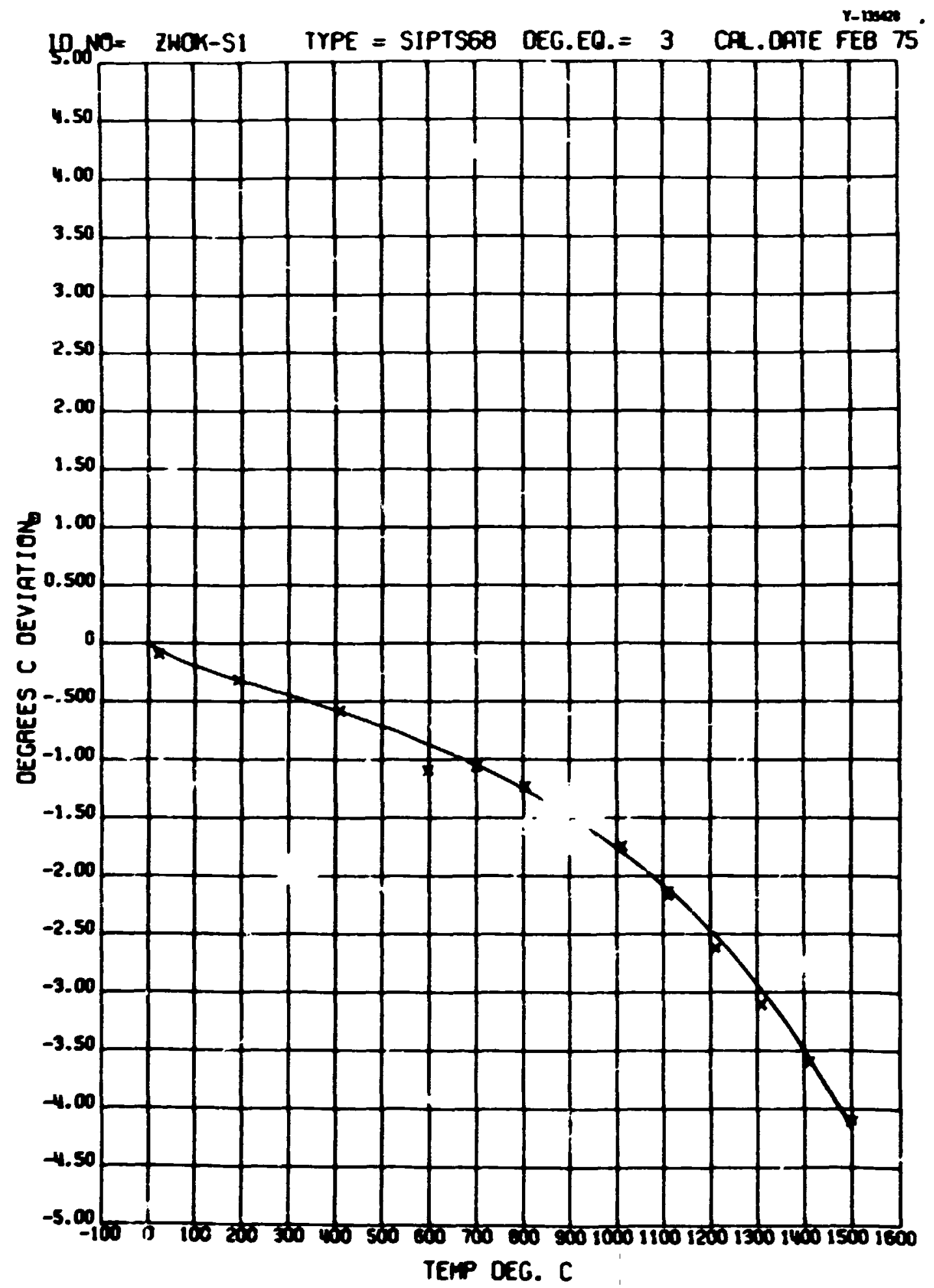

P1g. 2. Thermocouple deviation date for ZwOK SI from an exact Type $S$ thermocouple as a finction of temperature. 


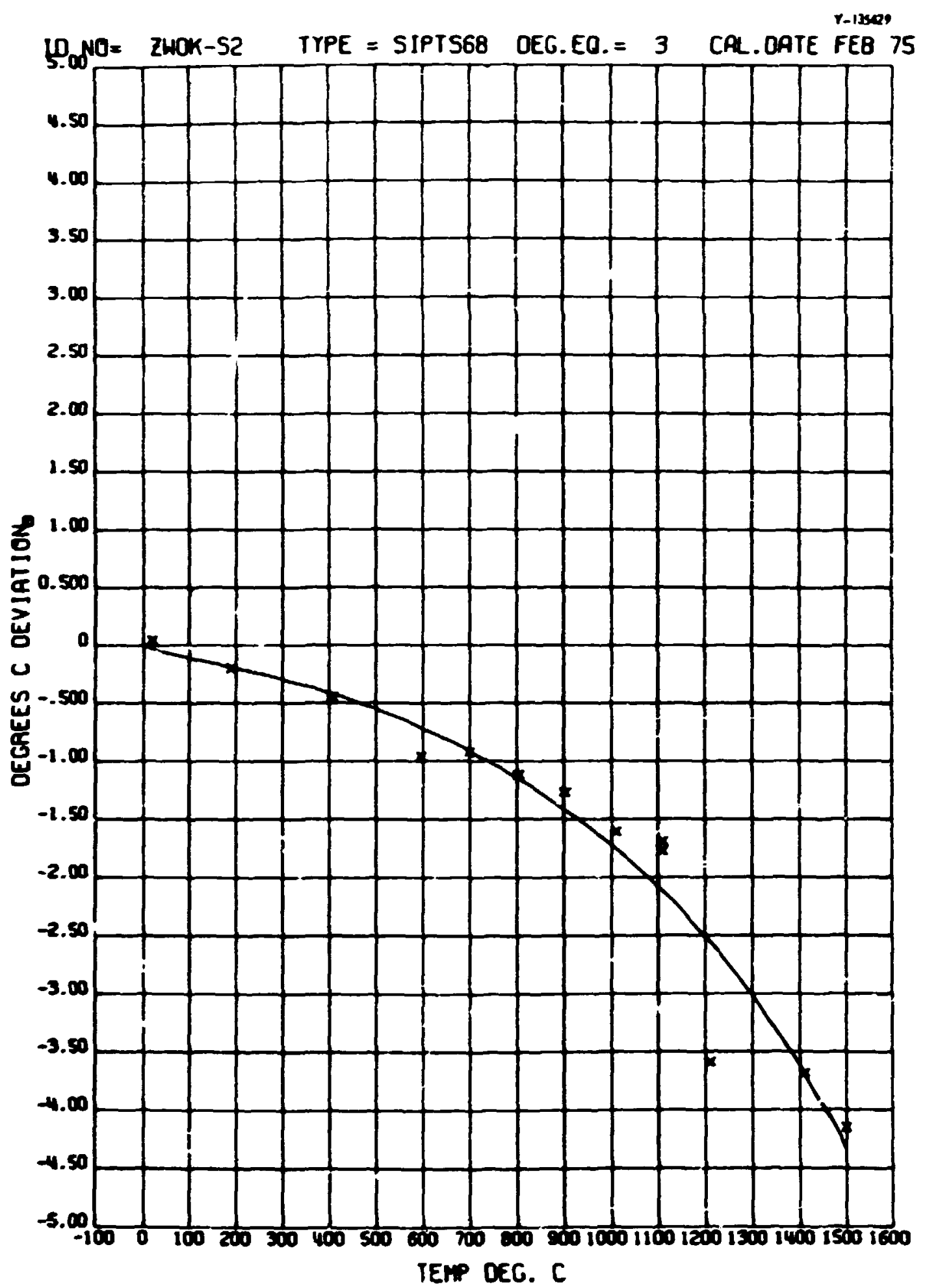

F1g. 3. Thermocouple deviation data for ZWOK S2 from an exact Type S thermocouple as a function of temperature. 
The data in run 1 were taken in the order:

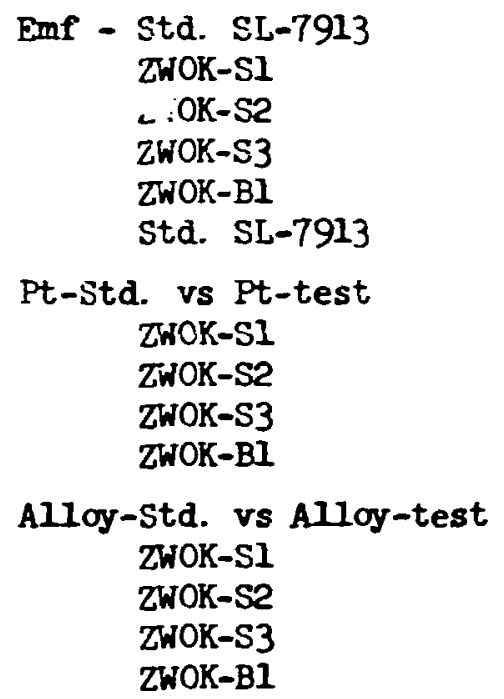

Emf-Std. SL-?o13

Maintaining this measurement schedule, allows one to use the behavior of SL-7913 to correct for furnace temperature drift at a given calibration temperature.

At a given temperature a linear drift of the furnace was assumed and the test emf's were adjusted accordingly. Table 5 gives the maximin differences observed between the two standard emf measurements at the rarious test temperatures.

Figure 4 is 3 repratuction of page 1 of the callbration toble for ZWOK-S-AVE for the range 0 to $49^{\circ} \mathrm{C}\left(32-120^{\circ} \mathrm{F}\right)$ in one degree steps. Entries in this table include the thermsl emf (millivolts) at each temperature as well as the temperature derivative (millivolts per degree) to allow interpolation. The complete table extended from 0 to $1499^{\circ} \mathrm{C}\left(32-2730^{\circ} \mathrm{P}\right)$.

Thermocouple 2 WOK-Bl, Pt $-6 \% \mathrm{Rh}$ vs Pt-30\% Rh, was included in Run -, and Fig. 5 compares its behavior to that reported in Monograph 125.' Except for the data scatter at 1100 and $1200^{\circ} \mathrm{C}\left(2012-2192^{\circ} \mathrm{P}\right)$ associated with electrical leakage, the calibration appears quite acceptable and a table similar to Fig. 4 was prepared for this combination. 


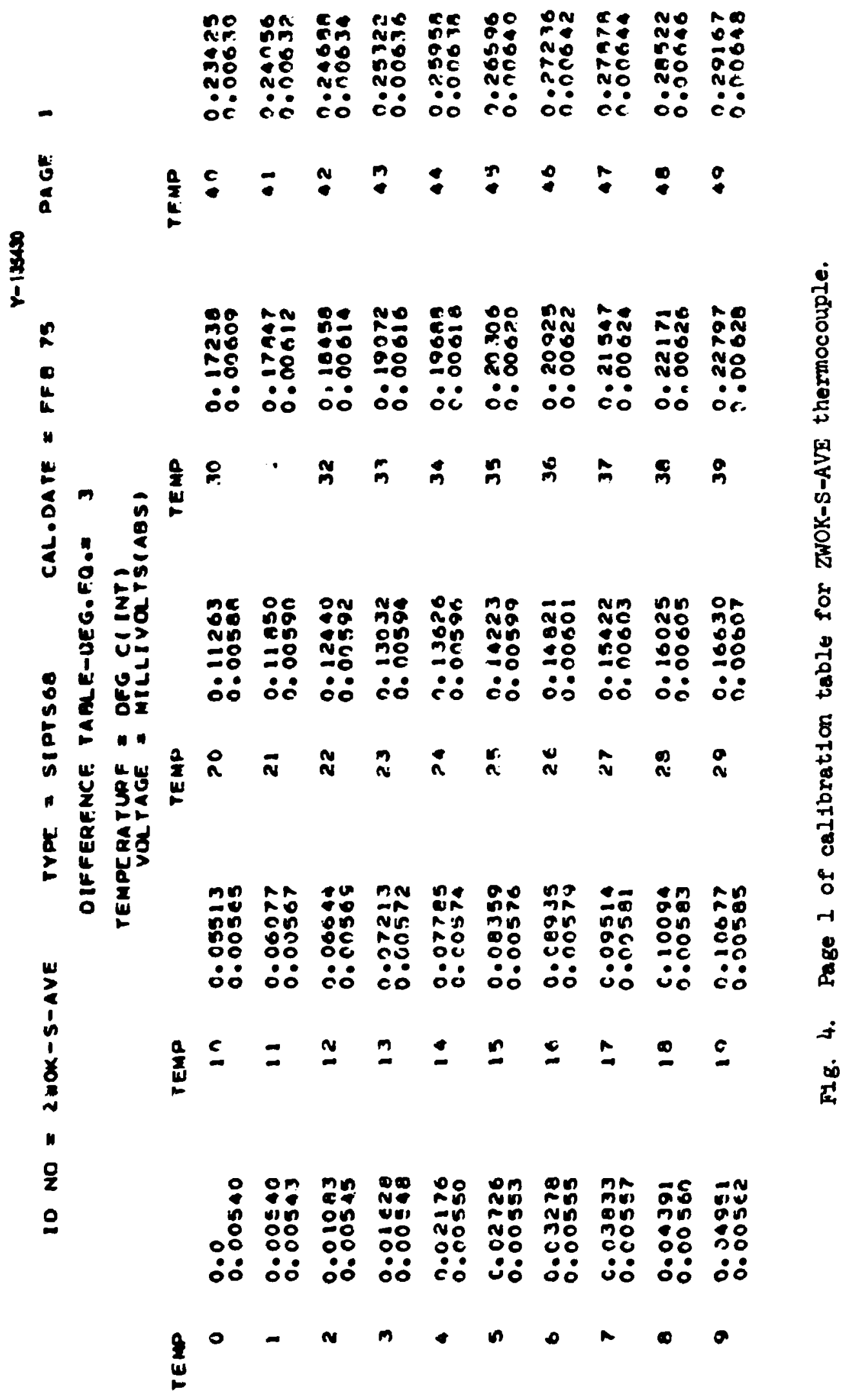


Table 5. Iinear Drift used in calibrations

\begin{tabular}{ccc}
\hline $\begin{array}{c}\text { Test } \\
{ }^{\circ} \mathrm{C}\end{array}$ & \multicolumn{1}{c}{${ }^{\circ} \mathbf{F}$} & Drift (uV) \\
\hline 21.45 & 70.61 & 0.3 \\
192 & 378 & 0.2 \\
409 & 768 & 1.3 \\
598.5 & 1109.3 & 0.2 \\
701 & 1294 & 1.7 \\
804 & 1472 & 0.4 \\
904 & 1659 & 1.5 \\
999 & 1830 & 2.0 \\
1109 & 2028 & 4.5 \\
1308 & 2386 & 2.3 \\
1412 & 2574 & 4.1 \\
1500 & 2732 & 3.2 \\
\hline
\end{tabular}

Retest of 0.010 in. Type S Material (Run 3)

A sample of a used 0.010 in Type $S$ thermocouple (old) was submitted for retest along with a new thermocouple (new), both made from the same materials previously calibraied. The calibration was run in a similar manner to that previously described, but the temperature range extended to only $1000^{\circ} \mathrm{C}$. Date vere taken both on heating and on cooling. Figures 6 and 7 show that no substantial difference was found between the "new" and the "ola". Both were within $\pm 0.5^{\circ} \mathrm{C}\left(0.9^{\circ} \mathrm{F}\right)$ of the ZwOK-SI therwocouple which was included as a reference along with loboratory standard SL-7913. SL-7913 was the same reference standard used in the first ZWOK calibration run.

R. L. Anderson

Netrology Research \& Development Laboratory Report of Calibration November 24, 1975 


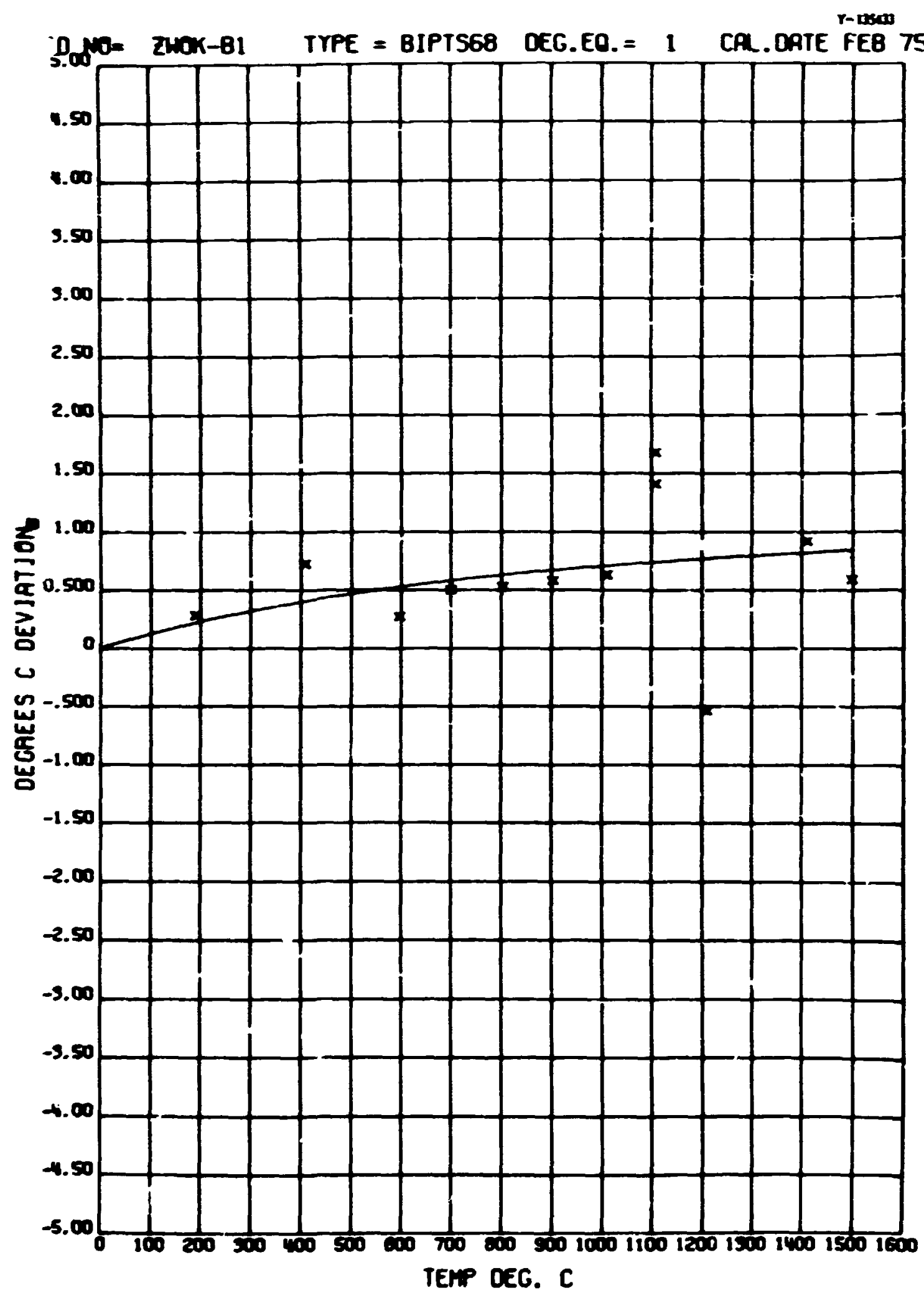

F18. 5. Thermocouple deviation data for ZWOK BI from NBS monograph 125 as a function of temperature. 


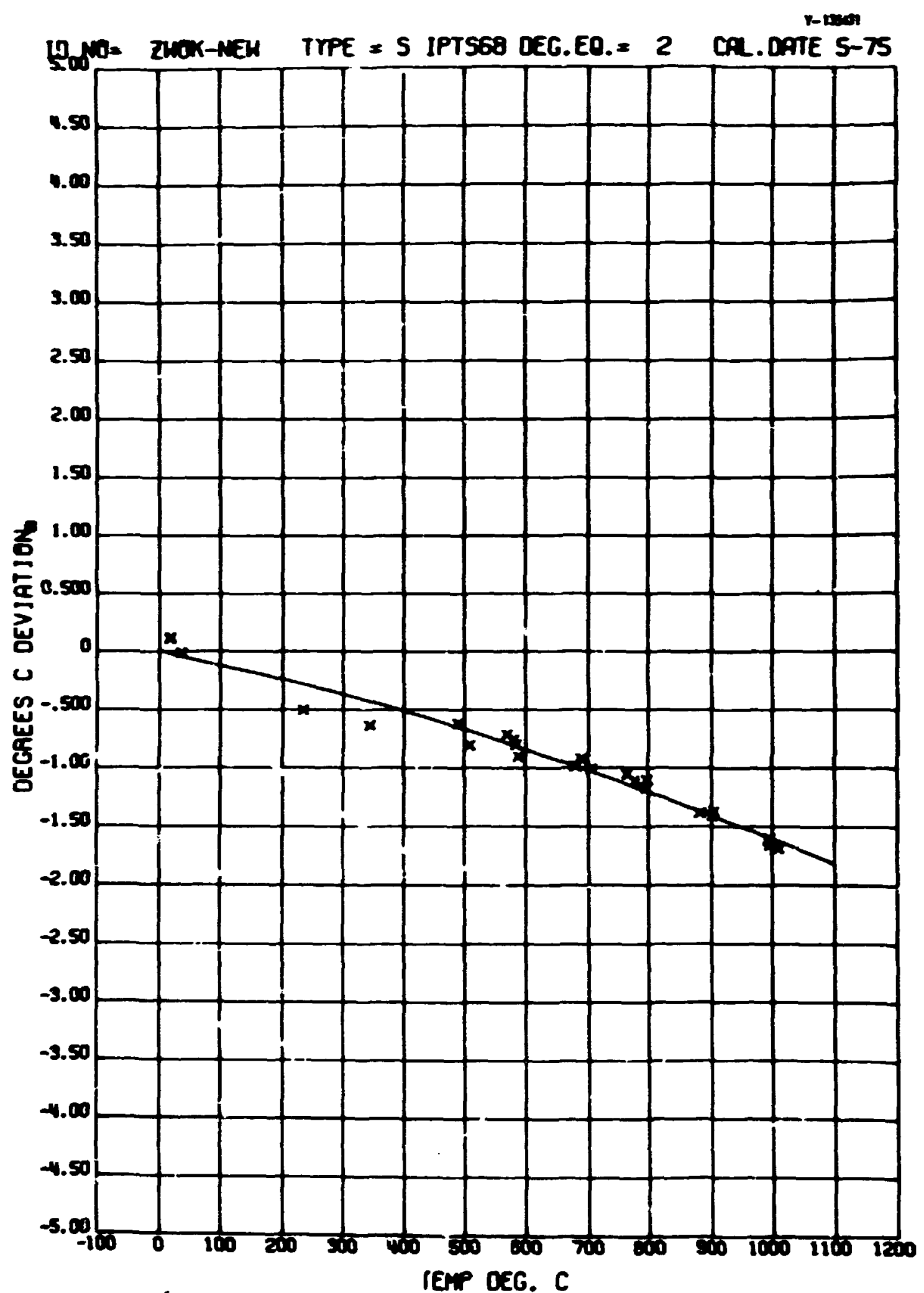

F1g. 6. Thermocouple deviation data for ZWOK-New from an exact Type $S$ thermocouple as a function of temperature. 
T-100

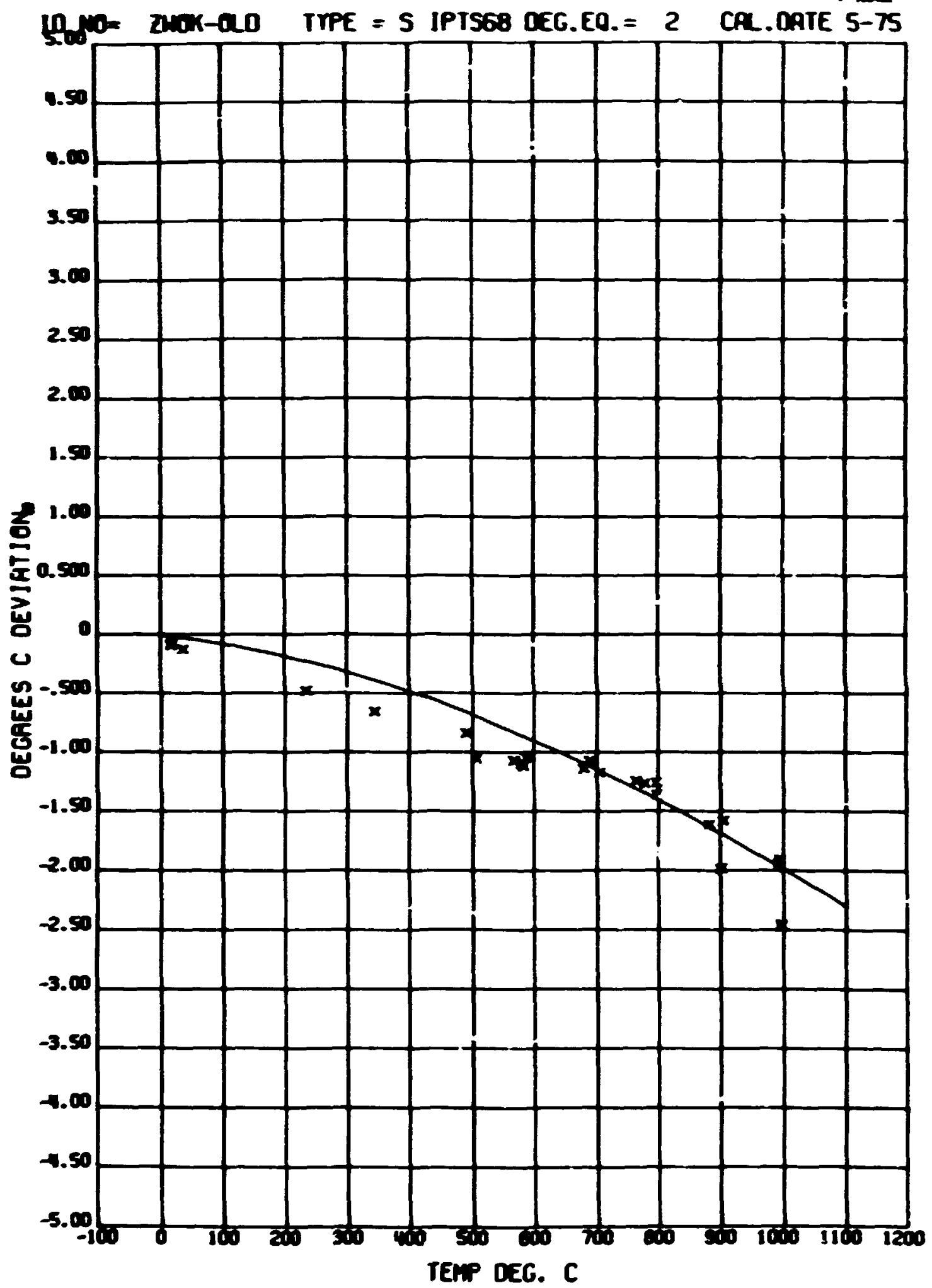

P1g. 7. Thermocouple deviation data for ZwOK-O1d from an exact Type $S$ thermocouple as a function of temperature. 
APPEDDX B

Referznce Junction Systes:

The Pt-104 Rh, Pt, Pt-30! Rh and Pt-64 Rh wires for each of the thermocuples of the experimental system (Miniziox, Maxizwox, and the arneeling furnece) were individually joined by eechnically turisting tc vingl-insulaier copper telephone wires to form the cold junctions. These celd functions were insulated from eact other by viwl tubing and vere placed two each in 7 (0.28 in.) dian glass tubes $25 \mathrm{~cm}$ (10 in.) long partially filled with a -10 on (4 in.) long colwa of nineral oil for thernal uniformity. A silastic conpound was extruded into the open end of exch glass tube to seal the cold function to mininize vater accualstion in the tubes. This procedure precludes electrical strunting between the cold junction wires.

The sealed glass tubes were nourited in a cork stopper wich forned the top of a Devar flask containing the $0^{\circ} \mathrm{C}\left(3 \bar{C}^{\mathrm{F}} \mathrm{F}\right)$ ice rater bath. Food theral contact of the cold functions with the bath was assured by the large L/D ratio of the tubes ( 36 ) and the nineral ofl coluci. Previous experiments have shown that similarly constructed cold functions obtain the bath temperature at a depth of imersion of less than $10 \mathrm{~cm}$ (4 in.)." Various combinations of water and ice forned from distilled and tap water obtain $0^{\circ} \mathrm{C}$ well within the $\pm 0.01^{\circ} \mathrm{C}$ linit specified in the foregoing error analysis. " The cold function used in the Matrology Laboratory thernocouple calfbration facility was of a sinilar design, and the thermal EPs assoclated with the copper wire circuit were found to be 0.015 wicrovolts $\left(\sim 0.003^{\circ} \mathrm{C}\right)$.

In the anner?.ing furnace cold junction systen the glass tubes vere fitted in a drilled copper blocis which was ilsersed in the bath. This copper block prorided further insur once that all of the cold junctions

D. L. McElroy, Progress Report 1, Theroccuple Resench Report for the Period Novemiber 1, 2936 to October 31, 1957, ORNL-2467 (March 1938).

†. P. Moore, R. S. Graves, T. G. Stradley, J. H. Hannah, and D. L. MeElroy, Some Thermal Transport Properties of a Limestone Concrete, ORIL-TIL-2644 (Aurgust 1969). 
rere at the sane teperature and served as a thermal inerts: block in mintaining the cold Junction tempereture constant during the time the ice buth weing changed. This was userul in long time diffuston anneals to prevent major changes in the control of the furnace temperature due to bath replenishent. 